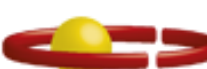 \\ UnC=Uв \\ Centro Universitárıo de Brasíla \\ CENTRO UNIVERSITÁRIO DE BRASÍLIA - UniCEUB \\ PROGRAMA DE INICIAÇÃO CIENTÍFICA
}

BRUNA LÍDICE DA SILVA DIAS

ENSINO DO DESENHO DA HABITAÇÃO POPULAR POR MEIO DE VÍDEO AULAS

BRASÍLIA

2018 


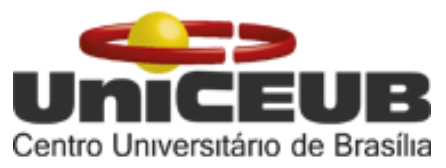

BRUNA LÍDICE DA SILVA DIAS

ENSINO DO DESENHO DA HABITAÇÃO POPULAR POR MEIO DE VÍDEO AULAS

Relatório final de pesquisa de Iniciação Científica apresentado à Assessoria de Pós-Graduação e Pesquisa.

Orientação: Eliete de Pinho Araujo.

BRASÍLIA

2018 


\title{
ENSINO DO DESENHO DA HABITAÇÃO POPULAR POR MEIO DE VÍDEO AULAS
}

\author{
Bruna Lídice da Silva Dias - UniCEUB, PIC voluntário em Arquitetura e Urbanismo \\ bruna.lidice@sempreceub.com
}

Eliete de Pinho Araujo. - UniCEUB, professor orientador

Eliete.araujo@ceub.edu.br

O presente estudo mescla Arquitetura, Educação e Cinema. Faz um "sobrevoo" divertido e educativo acerca dos meandros da Habitação Popular. Destaca valores do planejamento e construção da Casa Humilde, seu desenho e sistemas construtivos para sua execução. Isto, com consideração das especificidades culturais, ambientais, tecnológicas e regionais. É uma base para desenvolver metodologias de didática audiovisual direcionada a quem deseja aprender este tema. Como objetivo, ensinar Desenhos de Habitação Popular por Vídeo Aulas. Como metodologia, por meio de pesquisa literária, foram pesquisadas as casas do século XX em diferentes lugares do mundo e em seguida as habitações brasileiras. Desta forma foi possível analisar de modo ampliado as características das cassas pelo mundo e no Brasil. Essas casas se diferem não apenas pelos períodos históricos, mas também por suas concepções filosóficas. Os estudos sobre as casas do século XX são baseadas no livro $A$ boavida - Visita, casas da modernidade: Zaratustra, positivista, fenomenológica, desconstrutivista, existencialista, pragmática e loft nova-iorquino. Em seguida foi feita uma análise e resumo a respeito do primeiro capítulo do livro Arquitetura Popular Brasileira (Gunter, 2005). Foram analisados e pesquisados exemplos de moradias em tocas, morada da caatinga, dos areais, as casas dos coqueirais, dos mangues, dos pântanos, casas flutuantes, moradias dentro da floresta, casas dos campos e favelas urbanas. Como resultado foi possível verificar técnicas vernaculares em diferentes regiões brasileiras, em que as moradias são construídas com materiais encontrados próximos às construções. A pesquisa em si possibilitou conhecer a diversidade de habitações existentes no Brasil, como foram influenciadas e como são construídas.

Palavras-Chave: Habitação popular brasileira. Casas do século XX. Moradias 
1.INTRODUÇÃO

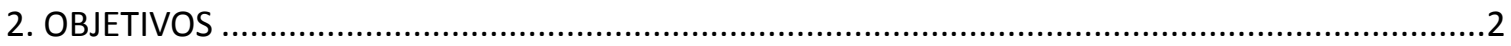

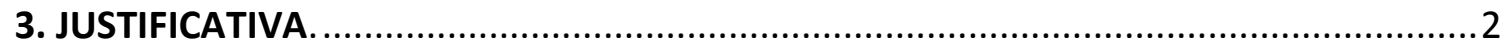

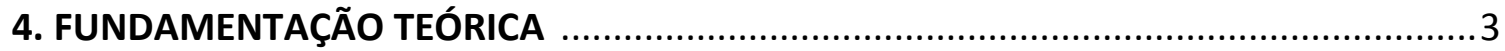

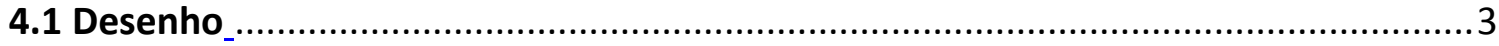

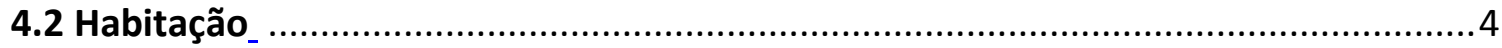

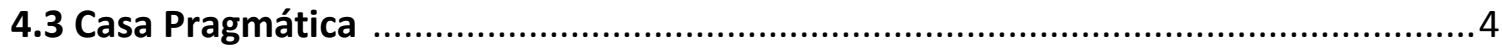

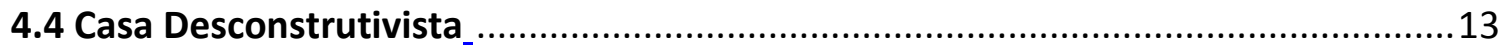

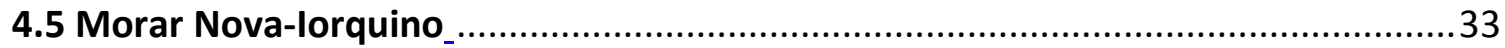

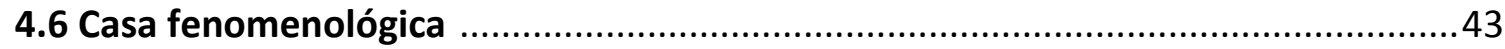

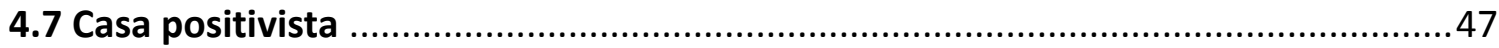

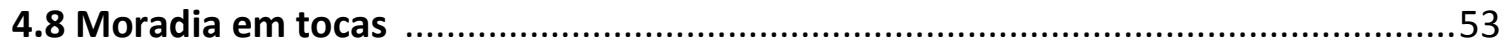

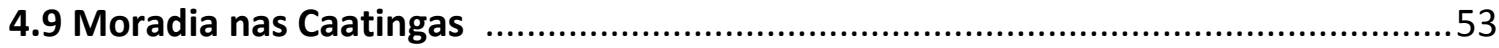

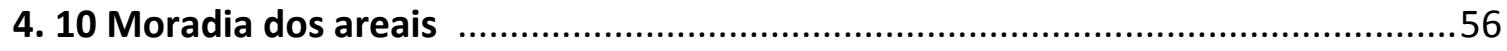

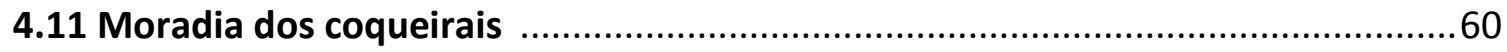

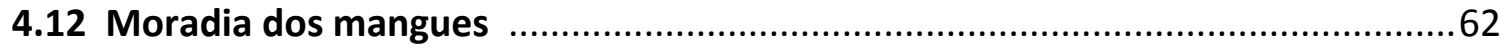

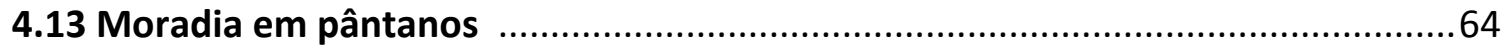

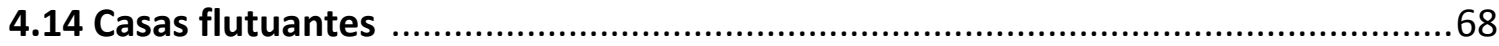

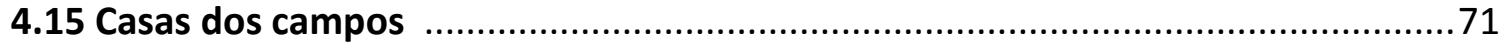

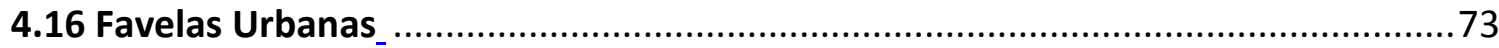

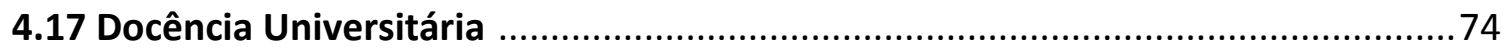

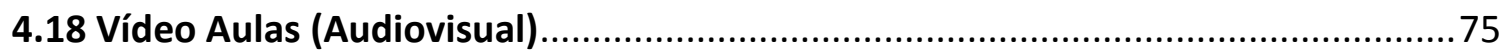

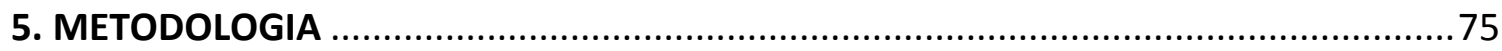

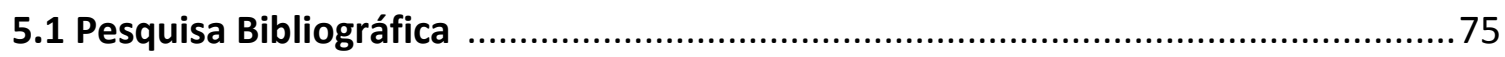

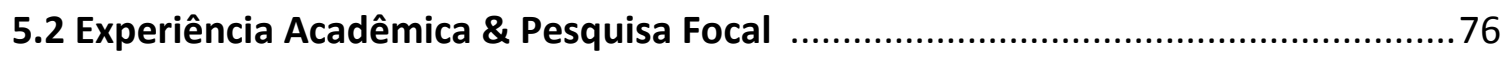

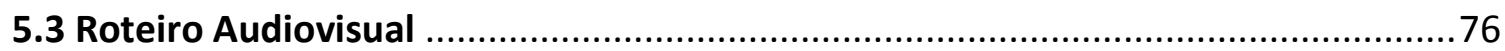

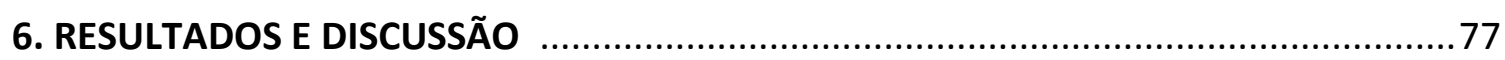

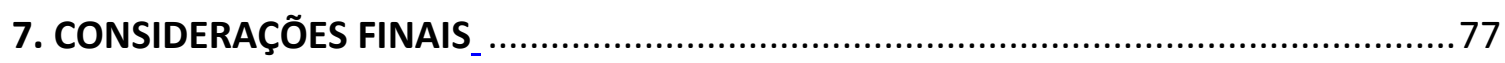

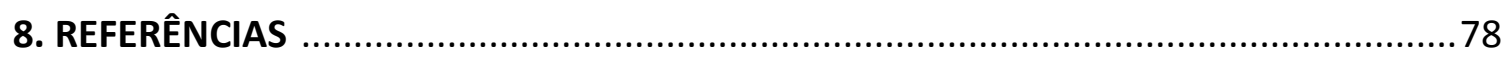




\section{INTRODUÇÃO}

Este trabalho relata diversos pontos e pesquisas que se fazem necessários na criação de um roteiro. Este, servirá como base para montar vídeo aulas capazes de auxiliar arquitetos e engenheiros no aprendizado sobre casa popular. Serão abordados quatro tópicos como fundamentos teóricas: desenho, habitação, docência universitária e vídeo aulas. Será abordado a importância do desenho junto a tecnologia para o estudante. Os fundamentos de habitação serão destrinchados, é utilizada bibliografias de dois autores que descrevem em seus livros características de algumas habitações. A primeira bibliografia trata das casas do século XX, no livro: A boa-vida - Visita guiada às casas da modernidade (ÁBALOS, 2008) que trata das casas: fenomenológica, desconstrutivista, existencialista, pragmática e loft nova-iorquino. A segunda decorre a respeito das habitações populares brasileiras do primeiro capítulo do livro: Arquitetura Popular Brasileira ( GUNTER, 2005), são elas: moradia em tocas, nas caatingas, dos areais, dos coqueirais, dos mangues, em pântanos, casas flutuante, dos campos e favelas urbanas. Essas casas se diferem não apenas pelos períodos históricos, mas também por suas concepções filosóficas. Docência universitária retrata a história universitária e a importância da universidade atualmente. Quanto as vídeo aulas apresentado a importância do cinema para a vida das pessoas e como podem contribuir com os estudantes.

De forma geral o estudo visa usar um dos meios de comunicação que surge com o avanço da tecnologia, em prol dos ensinamentos universitários.

\section{OBJETIVOS}

\section{Objetivo Geral}

Ensinar Desenhos de Habitação Popular por Vídeo Aulas.

\section{Objetivos Específicos}

- Entender o que é o desenho e como vem sendo desenvolvido dentro da arquitetura.

- Investigar as casas humildes brasileiras em diferentes épocas e regiões.

- Buscar exemplos dessas casas humildes, suas plantas arquitetônicas e suas técnicas construtivas.

- Esclarecer as características de cada habitação.

- Verificar os materiais utilizados.

- Analisar a comunicação audiovisual.

- Criar uma metodologia de transmissão de conteúdos de arquitetura por meio de imagens, sons e dramaticidade.

\section{JUSTIFICATIVA.}

Habitação popular é tema recorrente, necessário e premente na realidade sóciopolítica brasileira e latino-americana. $\mathrm{O}$ ambiente contemporâneo e arquitetônico favorece o ensino de conteúdos calcados em imagem, som e movimento. Instruir o desenho da habitação popular com desenvolvimento de metodologia de vídeo aulas.

Alunos focais detentores de conhecimentos tecnológicos.

De acordo com RODRIGUES (2005), cenas de filmes com planejamento cuidadoso, elaboração minuciosa e conteúdo direcionado criam "conexão" com o espectador e jamais 
são esquecidas... Quem nunca mais esqueceu aquela sequência do seu filme favorito?... Mesmo assistido há tempos atrás?... Muitos de nós! Vídeo Aulas pretende alcançar esta ligação e fixar conteúdos.

A pesquisa também vai impregnar o Roteiro com o(s) estilo(s) cinematográfico que será adotado na obra. Pode-se elucidar a inspiração no Neo-Realismo Italiano ou Nouvelle vague Francesa, exemplarmente para justificar provável abordagem "realista"; ou, a admissão do Expressionismo Alemão, por exemplo, quando a história fugir do contexto realista; ou ainda, qualquer outro estilo audiovisual que a pesquisa venha orientar, até mesmo, novamente, decisão eclética de mistura de estilos.

O texto que será elaborado também deverá preocupar-se com a viabilização da obra, optar sempre por baratear os custos de produção. Para tanto, deverá ser considerado a inserção de anúncios publicitários, tais como: comerciais de 15, 30 ou 60 segundos de duração; jingles com banda sonora e; peças institucionais. Contudo, todas estas "interferências" serão "orientadas" e agregadas ao tema, ou seja, deverão "dialogar" com Vídeo Aulas e conter aspectos educativos ligados à casa popular, porém, com magnitudes distintas e arenas visuais diferenciadas.

Por fim, esclarece-se que apesar desta preocupação com a viabilização da obra, o presente trabalho não pretende abordar a "Realização de Vídeo Aulas", principalmente, no tocante aos aspectos de "Produção, Pós-Produção e Distribuição" do filme. De tal modo, o trabalho atentar-se-á na pesquisa e no planejamento. Isto é, na etapa de elaboração chamada de "Pré-Produção Audiovisual". Nesta fase, contudo, não será descartada qualquer experiência de "Produção Piloto", isto, para definir e elucidar aspectos da obra que por ventura não tenham ficado devidamente esclarecidas no roteiro de planejamento.

Ensinar Desenhos de Habitação Popular por Vídeo Aulas é o objetivo geral. Para alcançar se faz necessário alguns objetivos específicos como: Investigar a casa humilde; buscar suas técnicas construtivas; verificar os materiais utilizados; pesquisar exemplos de casas, e suas respectivas plantas; esclarecer as característica de cada habitação, levando em consideração sua região, época e costumes.

\section{FUNDAMENTAÇÃO TEÓRICA}

\subsection{Desenho}

A representação de objetos tridimensionais num plano em projetos de arquitetura evoluiu gradativamente pelo tempo na história do desenho. Segundo Hoelscher e Dobrovilny (1968), um dos exemplos mais antigos de "planta e elevação" está no álbum de desenhos do vaticano, feito por Giuliano de Sangalo, notável escultor, arquiteto e engenheiro militar do século XII, em Firenze, Itália.

O desenho é maneira de expressão gráfica que tem por finalidade representar a forma, dimensão e posição dos objetos de acordo com as diferentes necessidades requeridas por modelos de arquitetura e engenharia. Utiliza-se um conjunto de linhas, números, símbolos, indicações e escritas para composição de uma "linguagem gráfica universal". 
Assim como a língua verbal ou escrita exige alfabetização, a execução e interpretação da linguagem gráfica do desenho exige "treinamento" específico, pois, por muitas vezes são utilizadas figuras bidimensionais para se representar a tridimensionalidade.

Ora defende-se que a representação inicial dos desenhos de arquitetura e engenharia, criação, deva ser à mão livre. Contudo, desde o fim do século $X X$, os desenhos passaram a ser desenvolvidos por computador, dentre vários modelos existentes se utiliza o CAD (Computer Aided Design): Tecnologia digital para geração 2D e 3D dos modelos. No Brasil este sistema ainda é uma das principais ferramentas para representar os desenhos.

Contudo existe outro sistema, cuja origem é contemporânea ao CAD, chamado BIM (Building Information Modeling). Nome remetido ao processo virtual de geração e manutenção do conjunto de informação 2D e 3D, referente a todos os desenhos feitos e mantidos para o ciclo de vida da edificação. As informações da tecnologia BIM podem ser utilizadas na documentação, quantificação, análises de desempenho, sistema construtivo e interferências nos projetos de Arquitetura, Engenharia e Construção (AEC). No Brasil de hoje o BIM encontra-se em ascensão, pois, compatibiliza todos os elementos de idealização e execução, isto, com a profunda minimização de erros nos processos, Manual de BIM (2014). Habitação

\subsection{Habitação}

A visitação das habitações herdadas do século $X X$, de maneira desapossada de preconceitos e identificadores profissionais, propiciada pela leitura do Livro de Iñaki Ábalos, Boa-vida (2001), serviu para observância da diversidade conceitual de residências e respectivas correntes de pensamentos. Despertou o prazer de projetar, refletir e viver intensamente. Este fenômeno ventilou o intelecto para futura proposição do desenho da

casa humilde. Ressaltam-se, a seguir, vários aspectos como fontes de referência teórica para o trabalho que se pretende.

\subsection{Casa Pragmática}

Da casa pragmática, absorver o conjugado heterogêneo das possibilidades do morar popular, com sua diversidade de referências essenciais, culturais e procedimentais. Lançar mão da cultura acadêmica para estabelecer conversações com o conceito do morar humilde. Consultar tecnologias de mercado para compor sistemas construtivos que minimizem o dispêndio de energia e choque ambiental. Reduzir a angústia popular com propostas habitacionais calcadas na execução progressiva e eficaz: intervenções de encaixe entre preceitos combinados. Atuar na reintegração de pessoas ao mundo, superar a dor da humilhação e privilegiar a falta de importância das diferenças. Investigar ocorrências do "passado" para confirmar referências para o "novo presente" habitacional. Exemplos de casa pragmática:

Casa Sustentável Piloto ZEB. Arquitetos: Snøhetta. Localização: Larvik, Noruega. Área: 220.0 m2. Ano do projeto: 2014 (Figuras 01 a 08). 


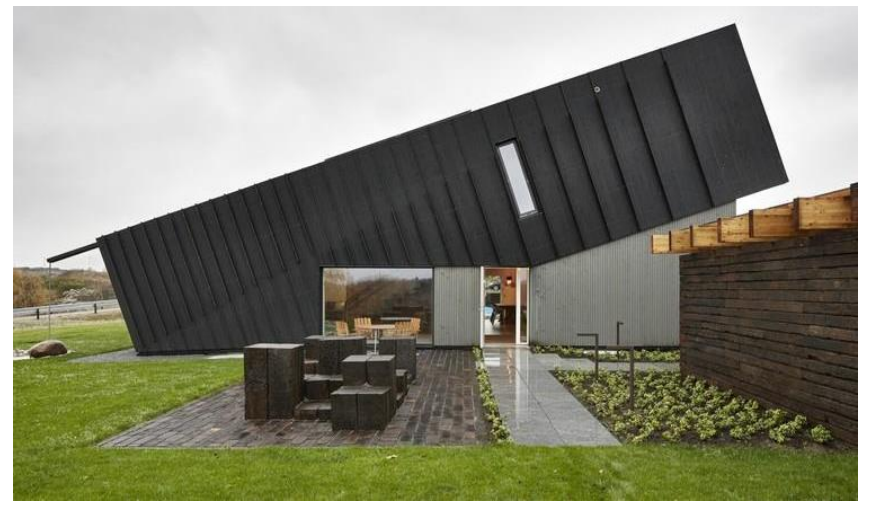

Figura 01. Casa Sustentável Piloto ZEB.

Fonte: https://bit.ly/2OVz16C. acessado em 15/11/2017.

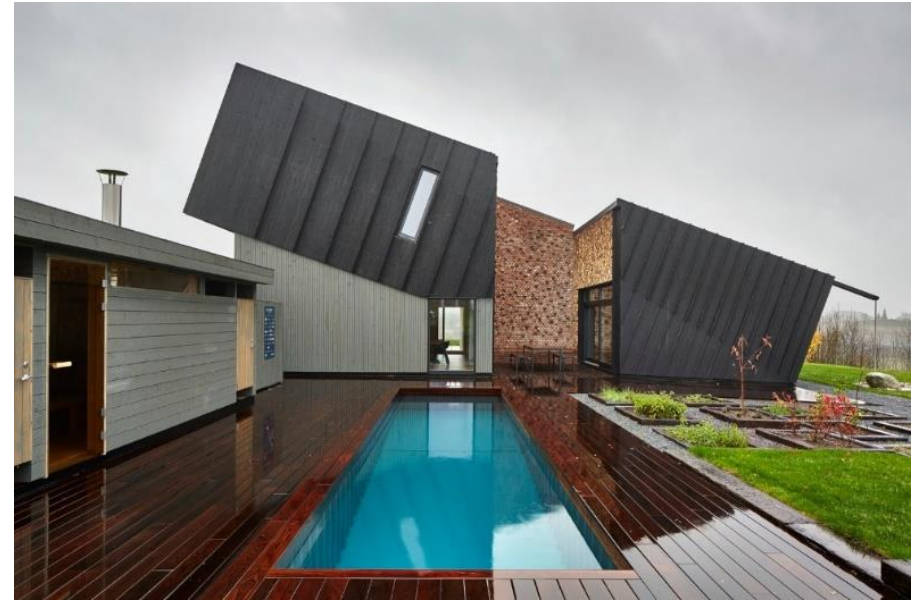

Figura 02. Vista posterior.

Fonte: https://bit.ly/2OVz16C. acessado em 15/11/2017.

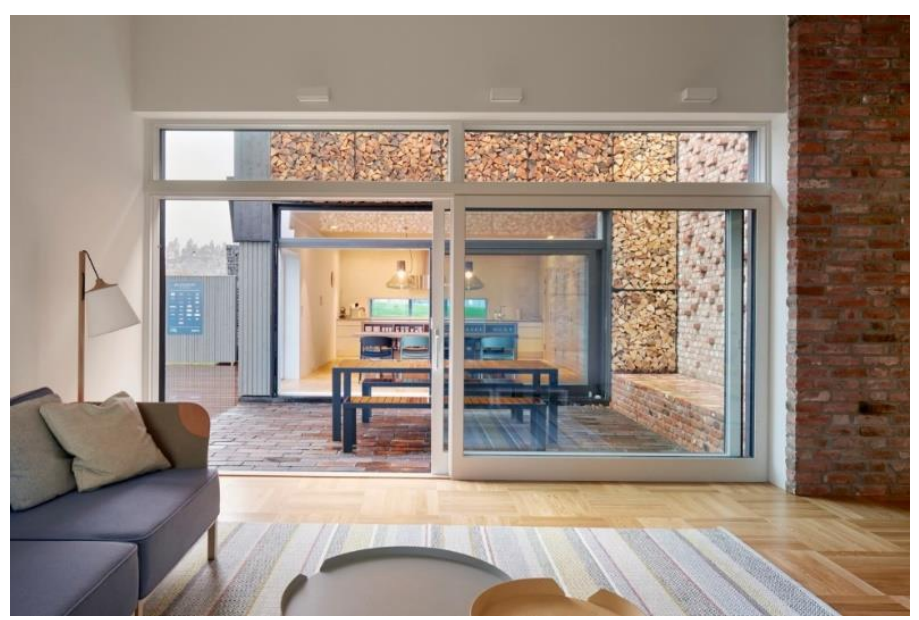

Figura 03. Perspectiva interna.

Fonte: https://bit.ly/2OVz16C. acessado em 15/11/2017. 


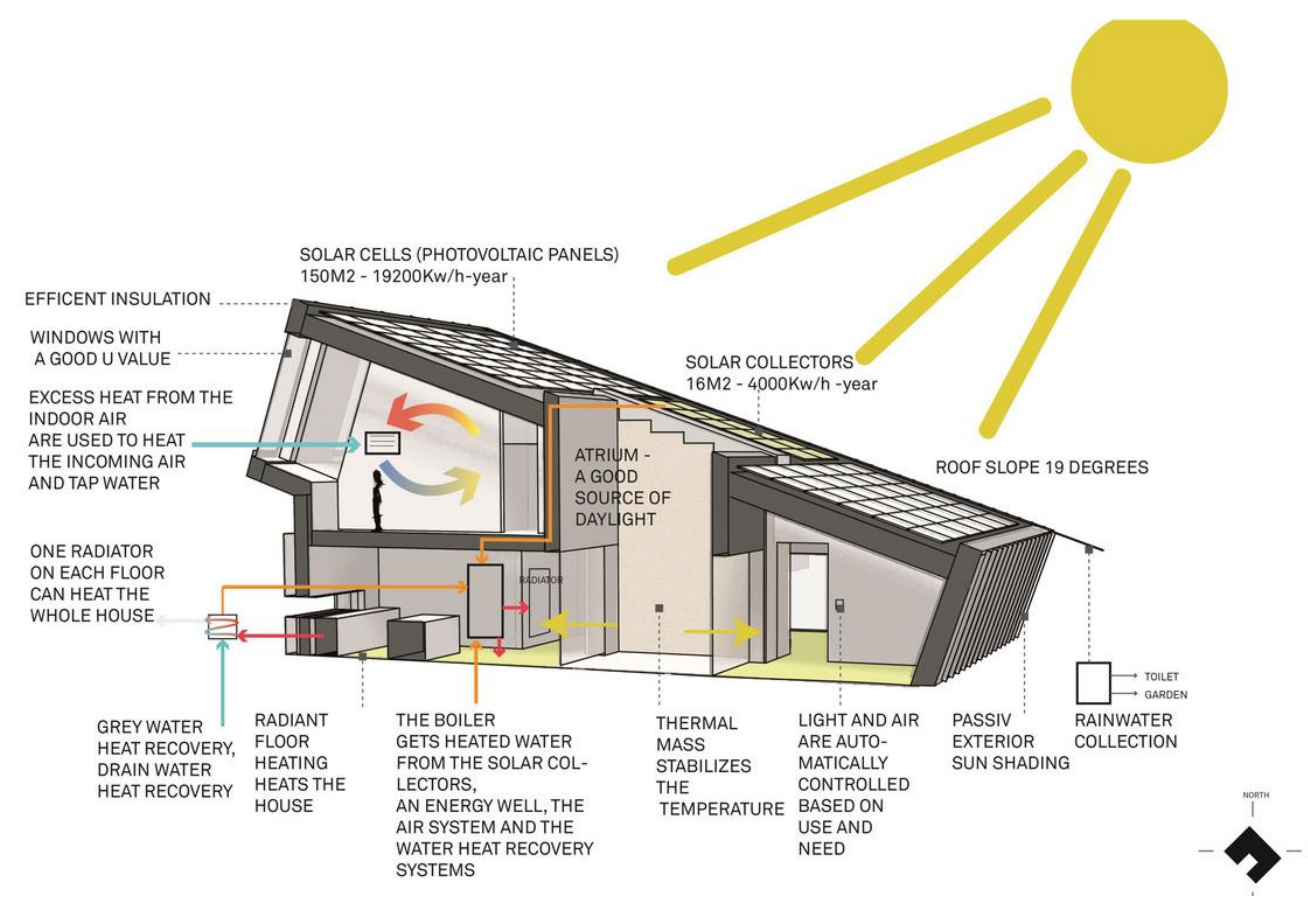

Figura 04. Diagrama.

Fonte: https://bit.ly/2OVz16C. acessado em 15/11/2017

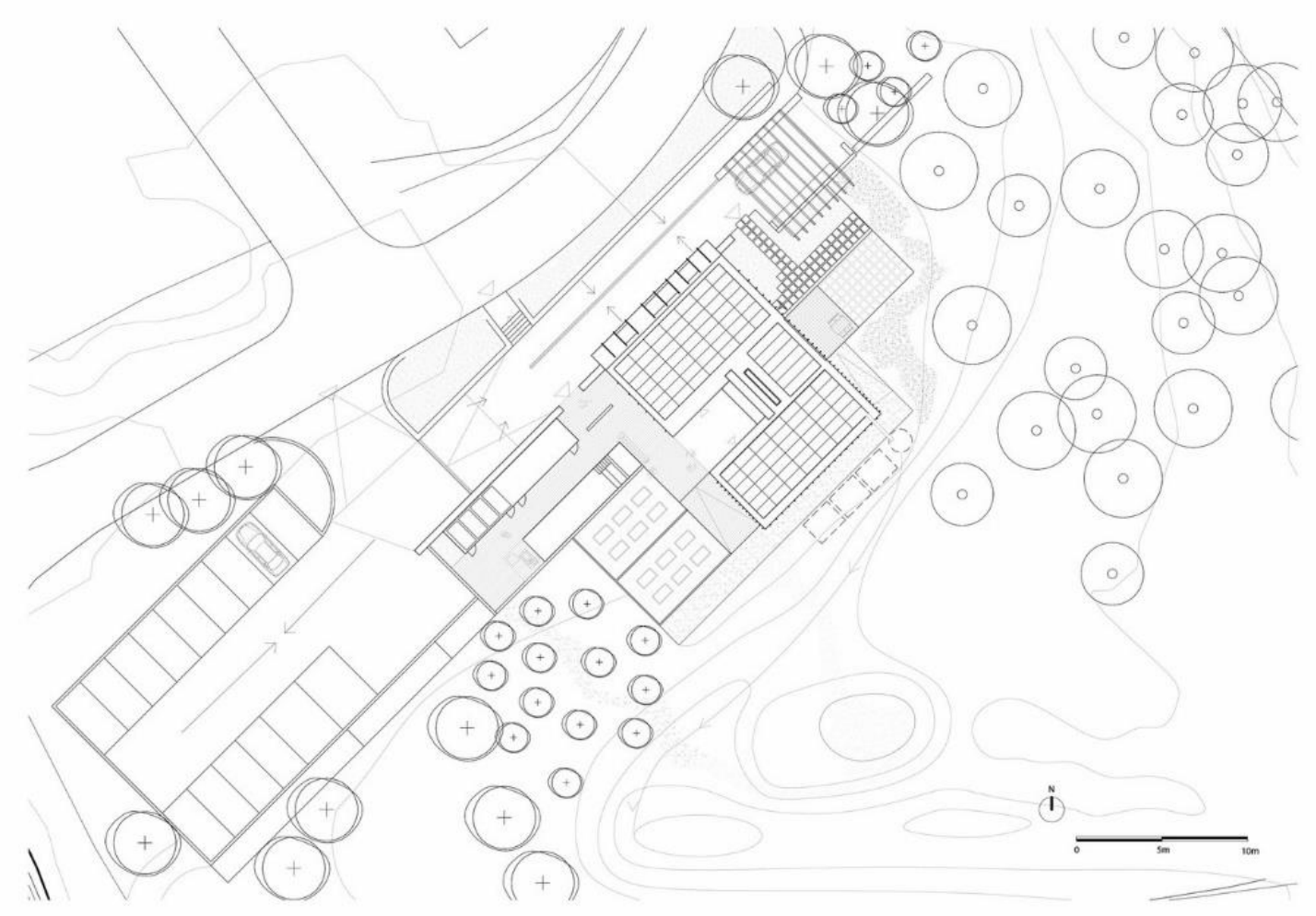

Figura 05. Planta de situação.

Fonte: https://bit.ly/2OVz16C, acessado em 17/10/2017. 

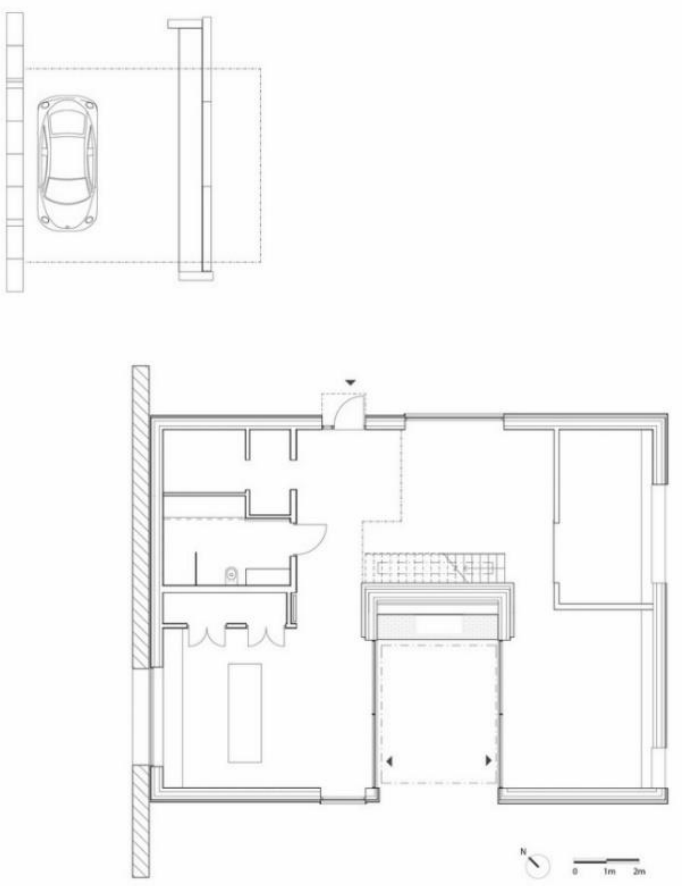

Figura 06. Planta baixa térreo.

Fonte: https://bit.ly/20Vz16C. acessado em 15/11/2017.

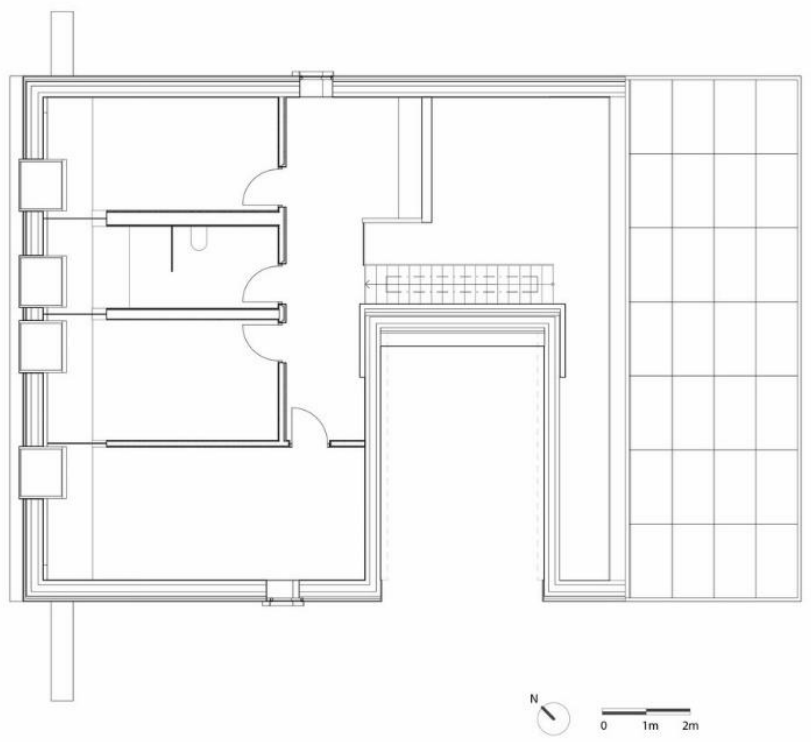

Figura 07. Planta baixa 10 pavimento.

Fonte: https://bit.ly/20Vz16C. acessado em 15/11/2017. 

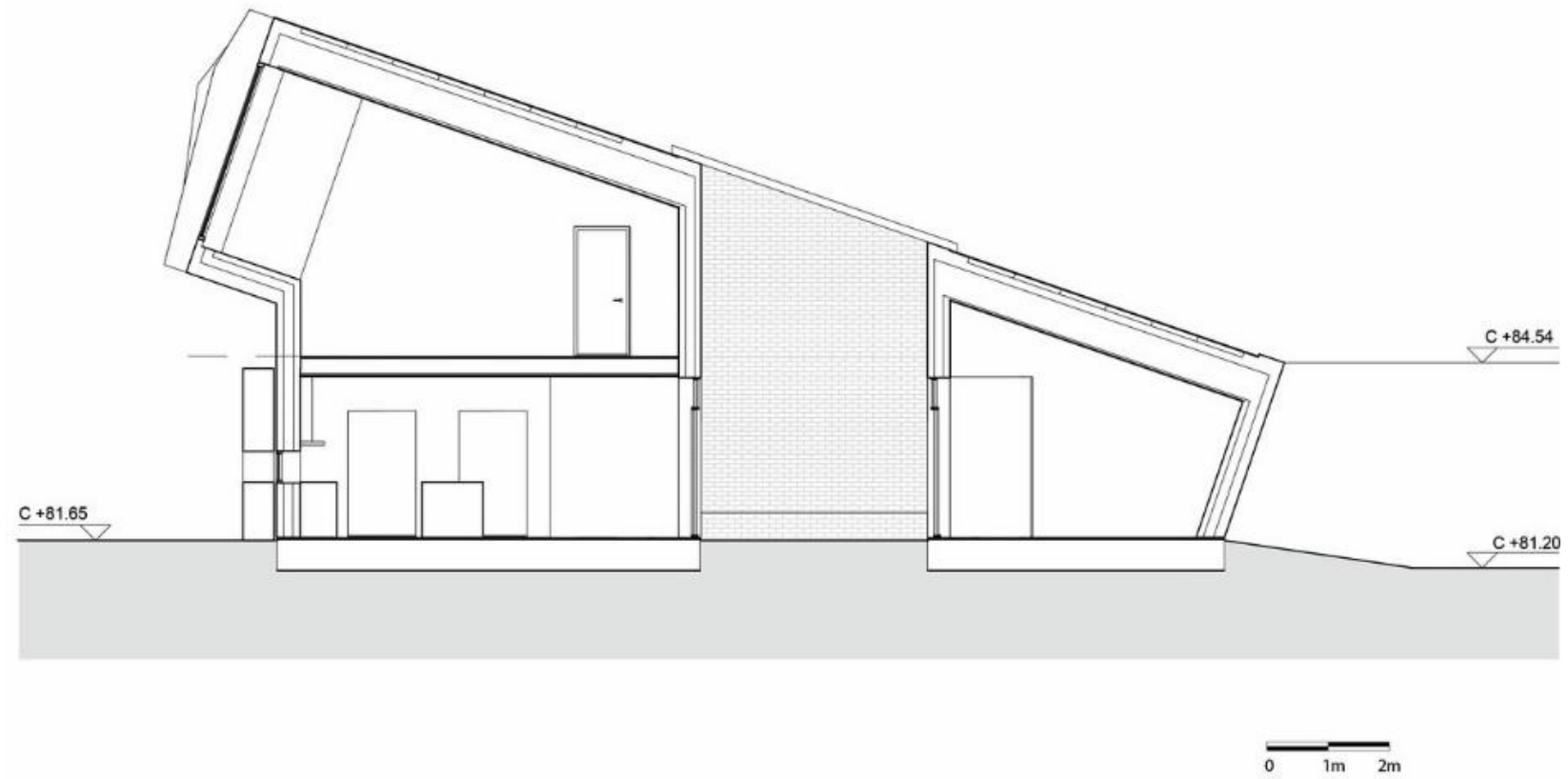

Figura 08. Corte.

Fonte: https://bit.ly/2OVz16C. acessado em 15/11/2017.

- $\quad$ Casa 10x10. Arquitetos: Oficina de Arquitetura. Localização: São Paulo, Brasil. Autora: Lêda Brandão. Área: 160.0 m2. Ano do projeto: 2016 (Figuras 09 a 14).

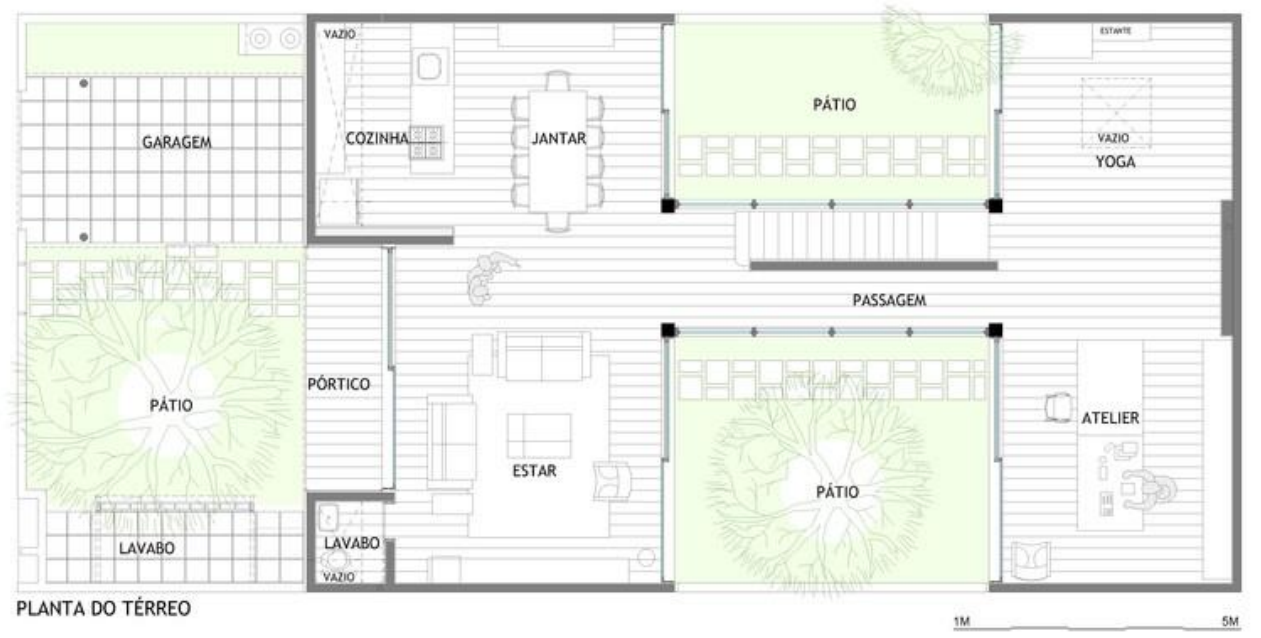

Figura 09. Planta baixa do térreo.

Fonte: https://bit.ly/2wf9u0E,acessado em 15/11/2017. 


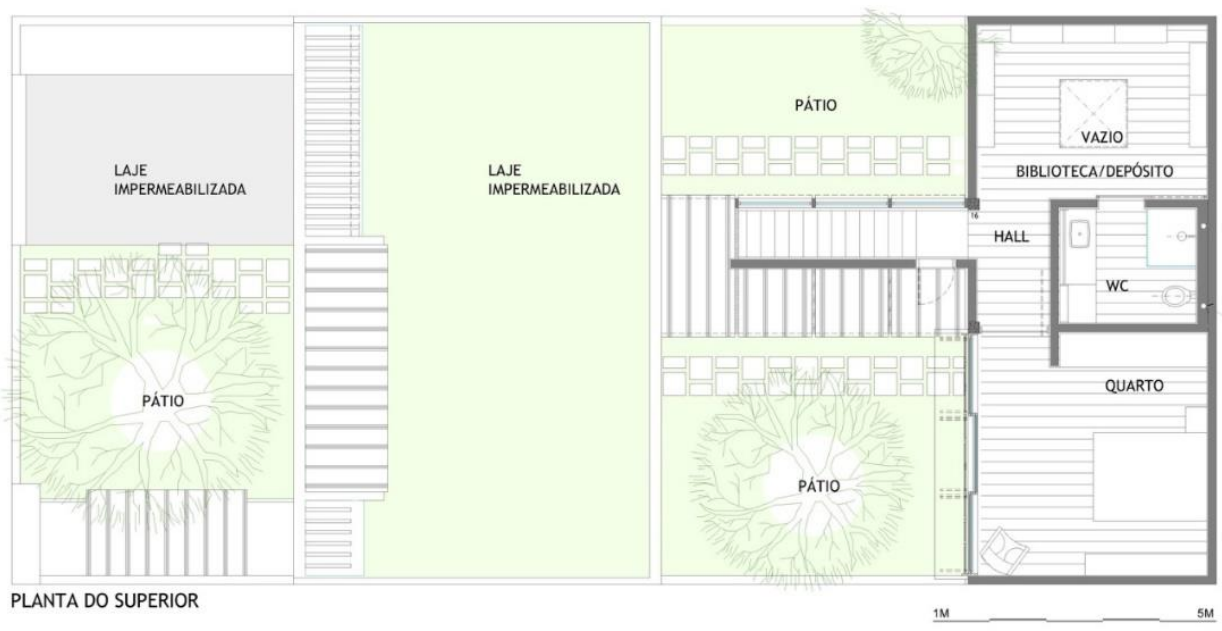

Figura 10. Planta baixa pav. Superior.

Fonte: https://bit.ly/2wf9u0E,acessado em 15/11/2017.

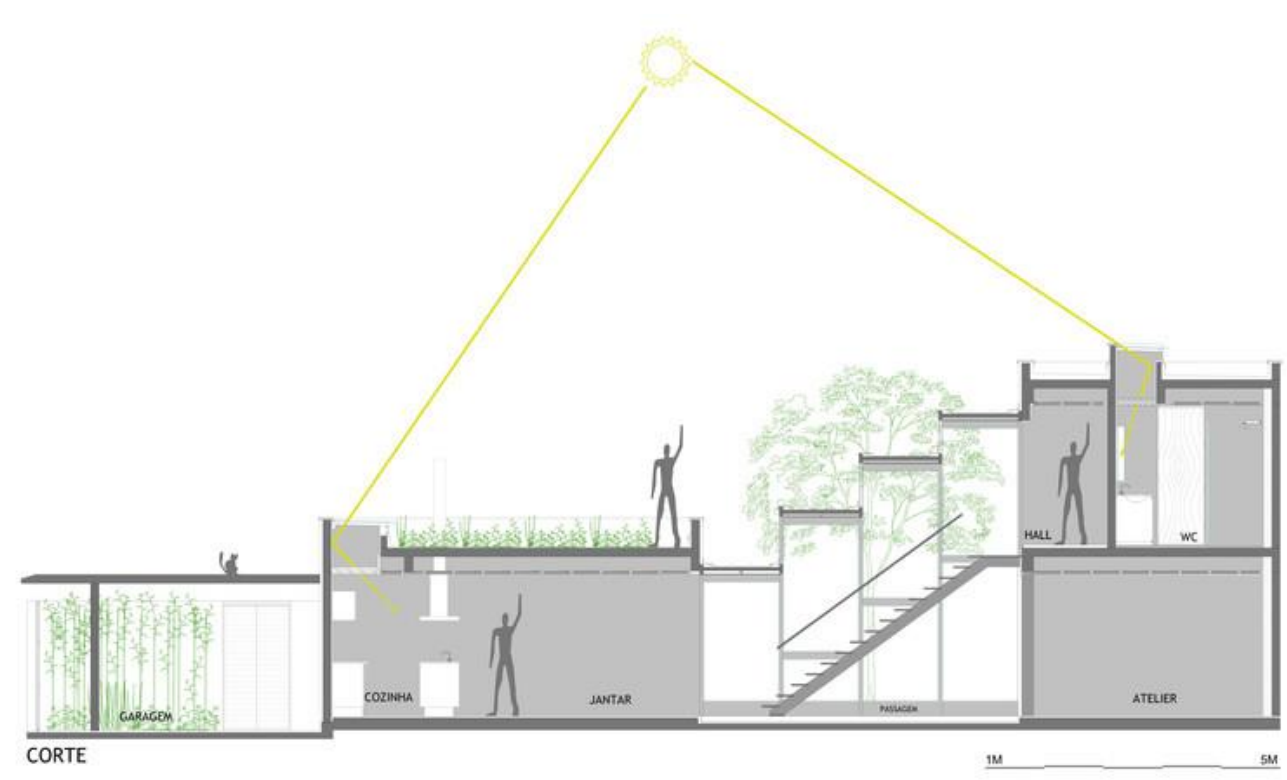

Figura 11. Corte esquemático.

Fonte: https://bit.ly/2wf9u0E,acessado em 15/11/2017. 


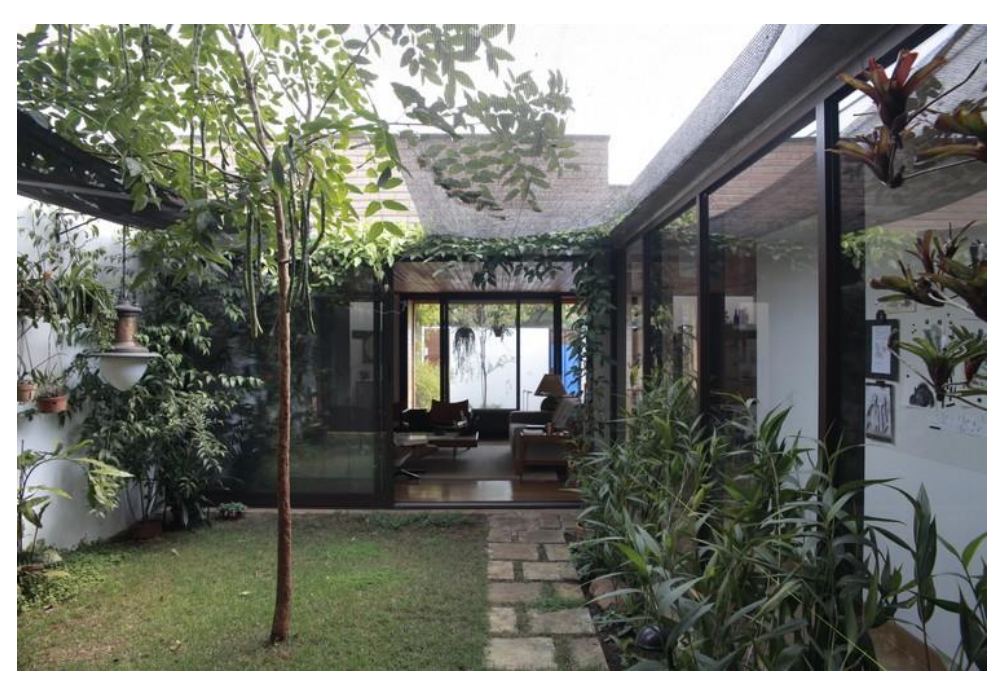

Figura 12. Perspectiva interna.

Fonte: https://bit.ly/2wf9u0E,acessado em 15/11/2017.

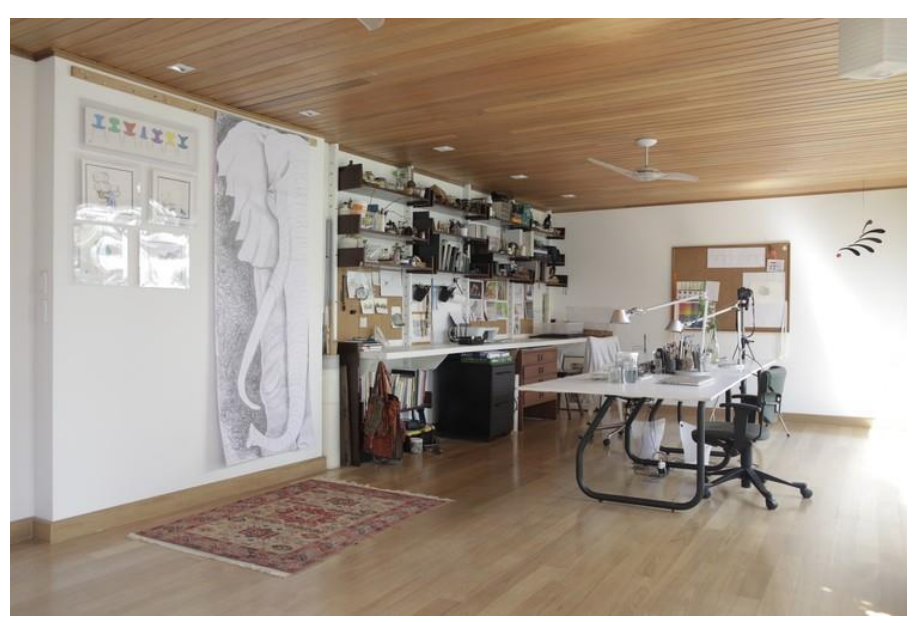

Figura 13. Perspectiva interna.

Fonte: https://bit.ly/2wf9u0E,acessado em 15/11/2017.

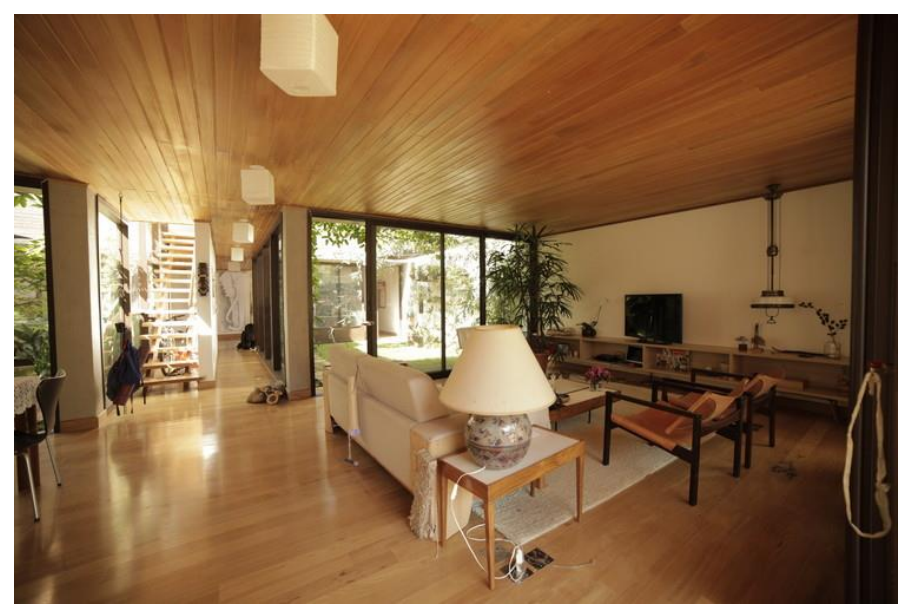

Figura 14. Perspectiva interna.

- Fonte: https://bit.ly/2wf9u0E,acessado em 15/11/2017. 
Residência Caixa de Música. Arquitetos: Scott | Edwards. Architects. Localização: Portland, Estados Unidos. Arquitetos Responsáveis: Rick Berry, Joe Broders, Kelly Edwards. Área: 601 $\mathrm{m}^{2}$. Ano do projeto: 2015 (Figuras 15 a 19).

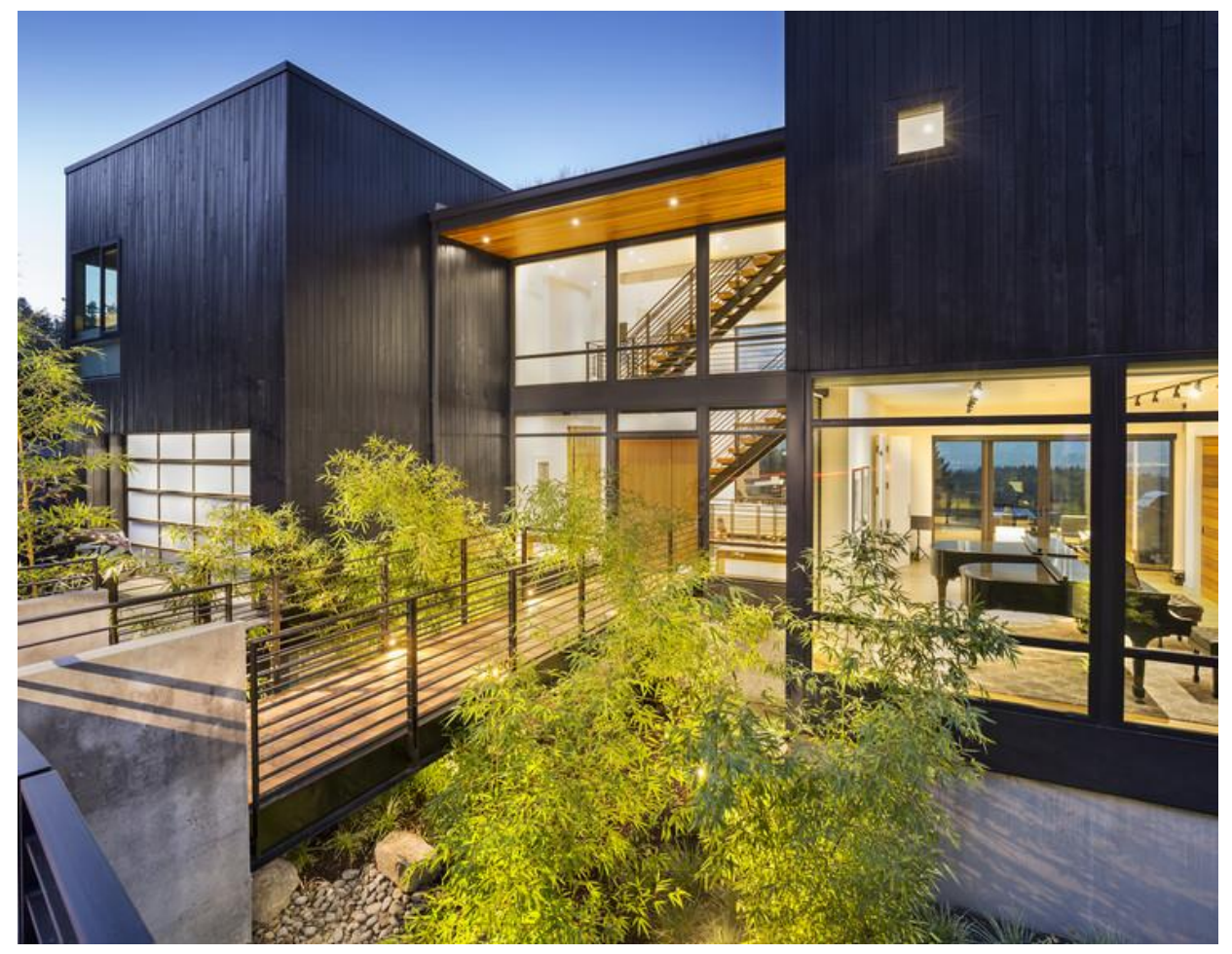

Figura 15. Perspectiva externa.

Fonte: https://bit.ly/2MHQrpJ, acessado em 15/11/2017.
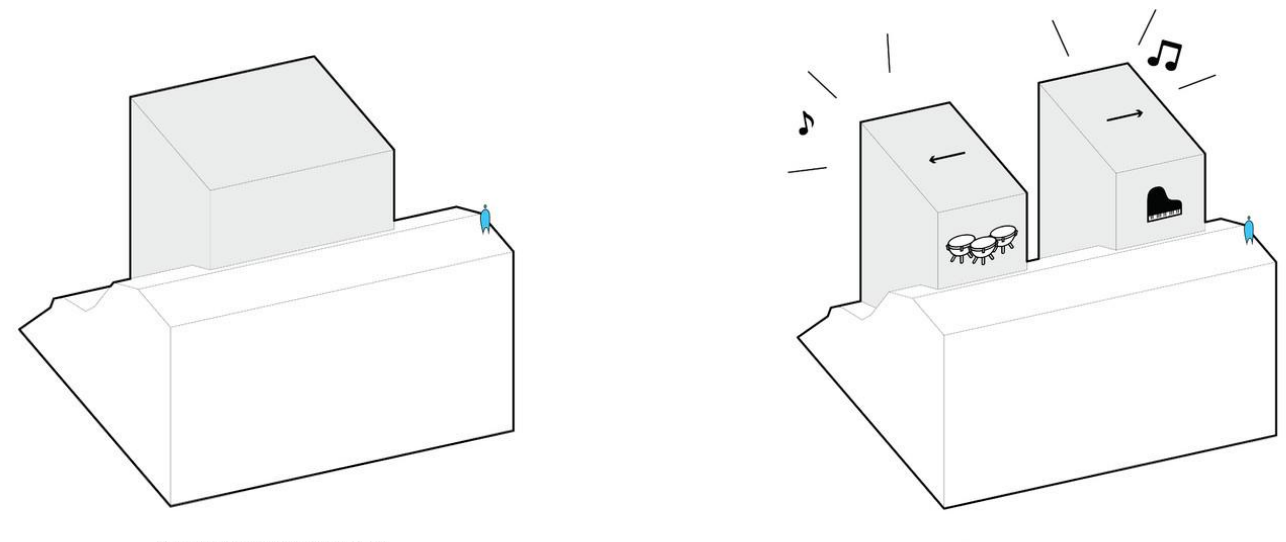

Figura 16. Diagramas.

Fonte: https://bit.ly/2MHQrpJ, acessado em 15/11/2017. 


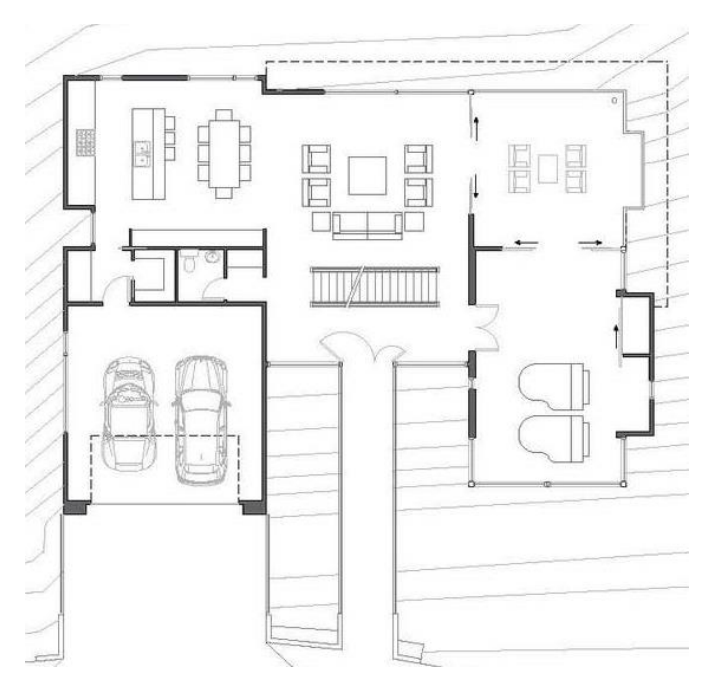

Figura 17. Planta baixa térreo.

Fonte: https://bit.ly/2MHQrpJ, acessado em 15/11/2017.

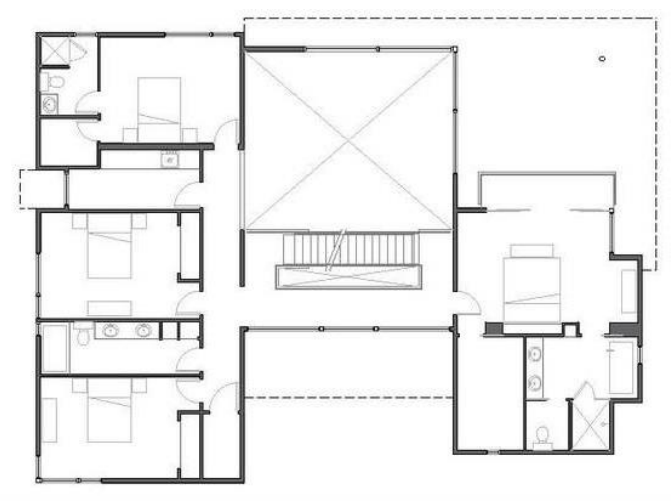

Figura 18. Planta baixa 1ㅇ pavimento.

Fonte: https://bit.ly/2MHQrpJ, acessado em 15/11/2017.

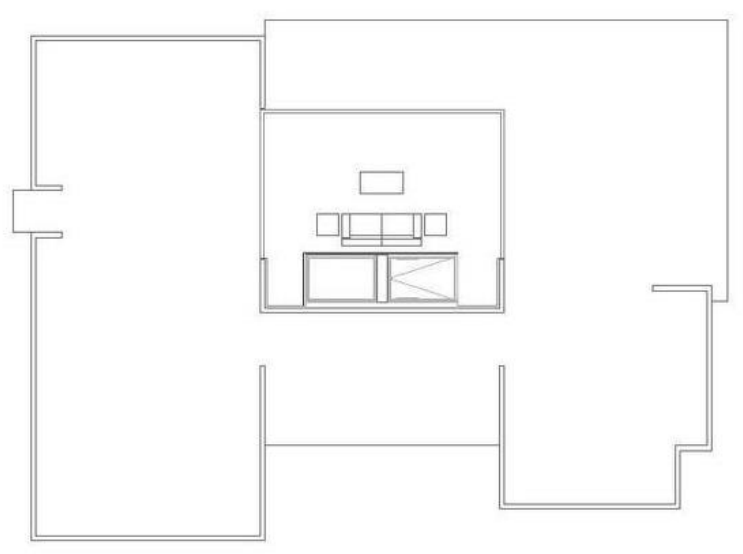

Figura 19. Planta baixa 2o pavimento.

Fonte: https://bit.ly/2MHQrpJ, acessado em 15/11/2017. 


\subsection{Casa Desconstrutivista}

Do habitar desconstrutivista, aspirar público e privado adequados aos processos de transformação da vida popular. Lançar mão da acidentalização, casualização e arquitetura habitacional randômica. Integrar apegos visíveis e concentrar adequadamente residências ao cotidiano do povo, uma espécie de complexidade "biológica" urbana. Entendimento dos diagramas específicos populares invisíveis. Criar processos de coerência, aparelhamento, rotinas e arranjo de propostas de morar com intenções de alteração da realidade desprovida. Resguardar o individualismo no conjunto das afinidades populares. Criar o espaço para o sujeito social, braço preparado e globalizado economicamente para interagir na sua região.

Exemplos de casas desconstrutivistas:

Residência Binh.Arquitetos: VTN Architects. Localização: Ho Chi Minh, Vietnã. Arquiteto Responsável: Vo Trong Nghia: Equipe de Projeto Masaaki Iwamoto, Chiang HsingO, Nguyen Tat Dat, Nguyen Duy Phuoc, Takahito Yamada. Área: 233.0 m2. Ano do projeto: 2016 (Figuras 20 a 27).

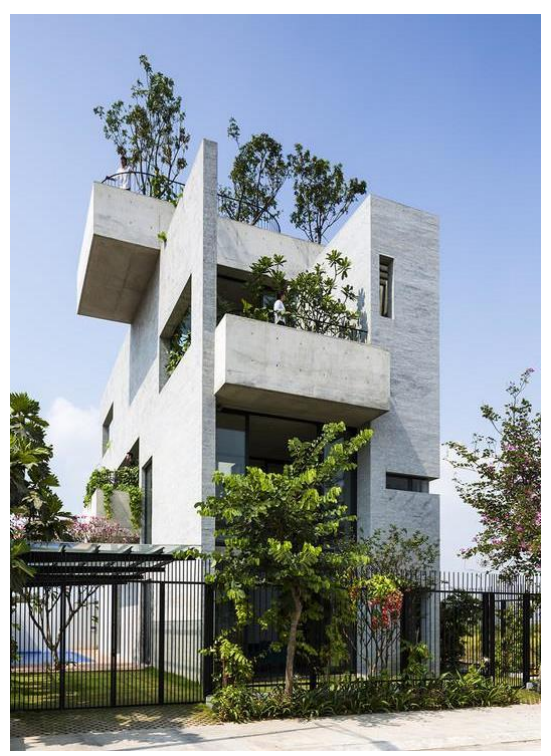

Figura 20. Perspectiva externa.

Fonte: https://bit.ly/2PrBZRu, acessado em 17/10/2017.

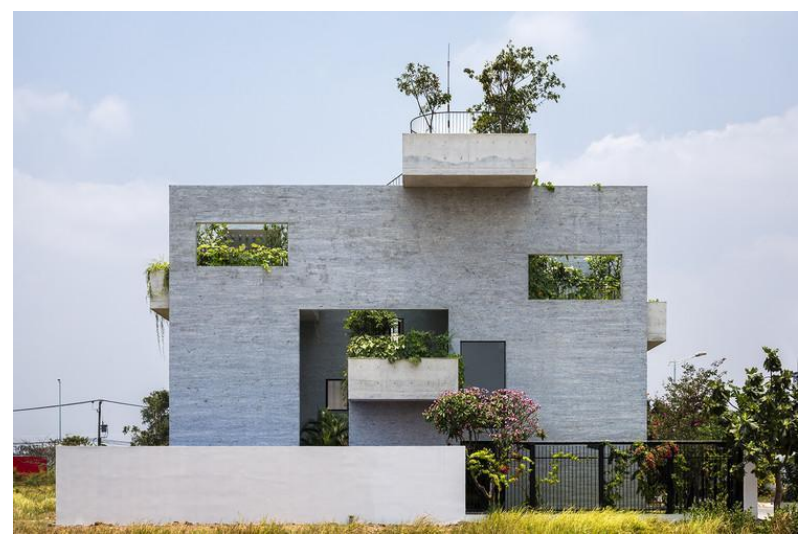

Figura 21. Perspectiva interna. 
Fonte: https://bit.ly/2PrBZRu, acessado em 17/10/2017.

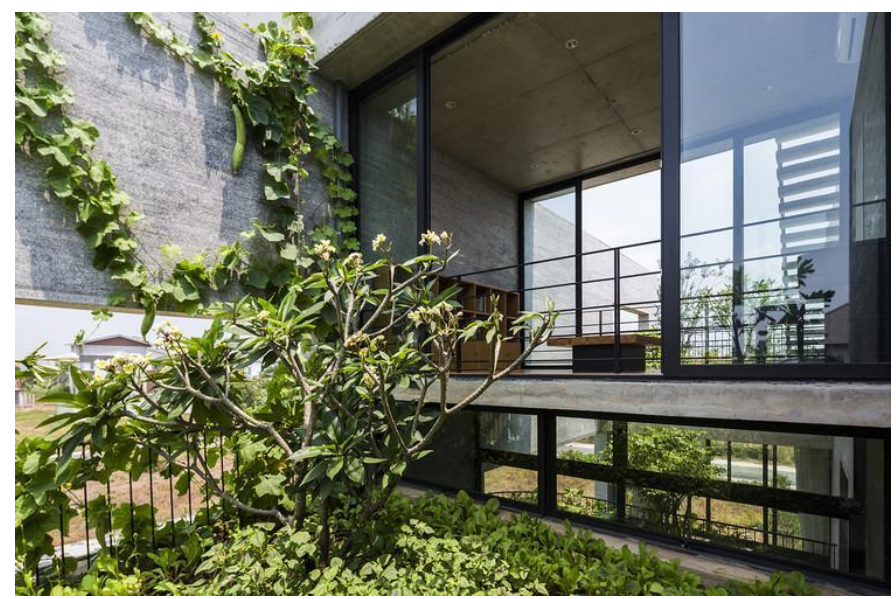

Figura 22. Perspectiva interna.

Fonte: https://bit.ly/2PrBZRu, acessado em 17/10/2017.

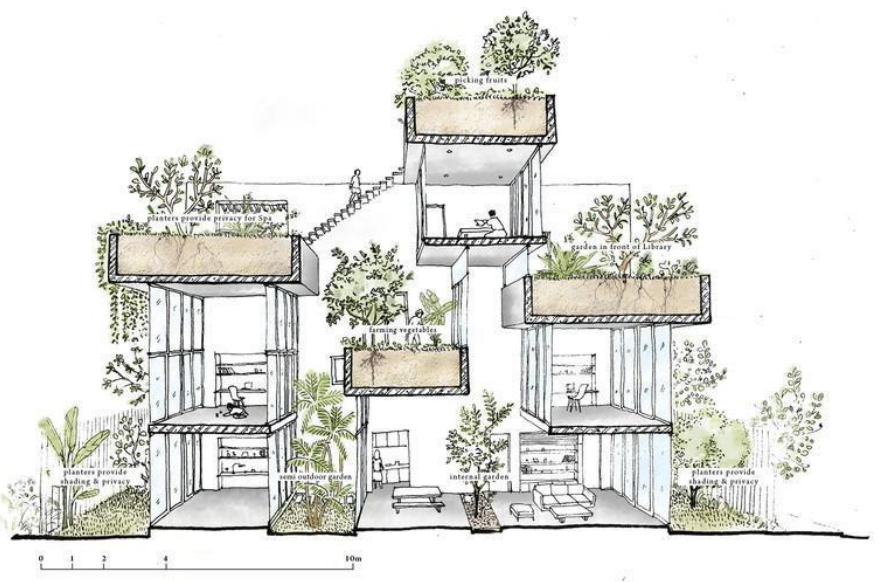

Figura 23. Corte exquemático.

Fonte: https://bit.ly/2PrBZRu, acessado em 17/10/2017.

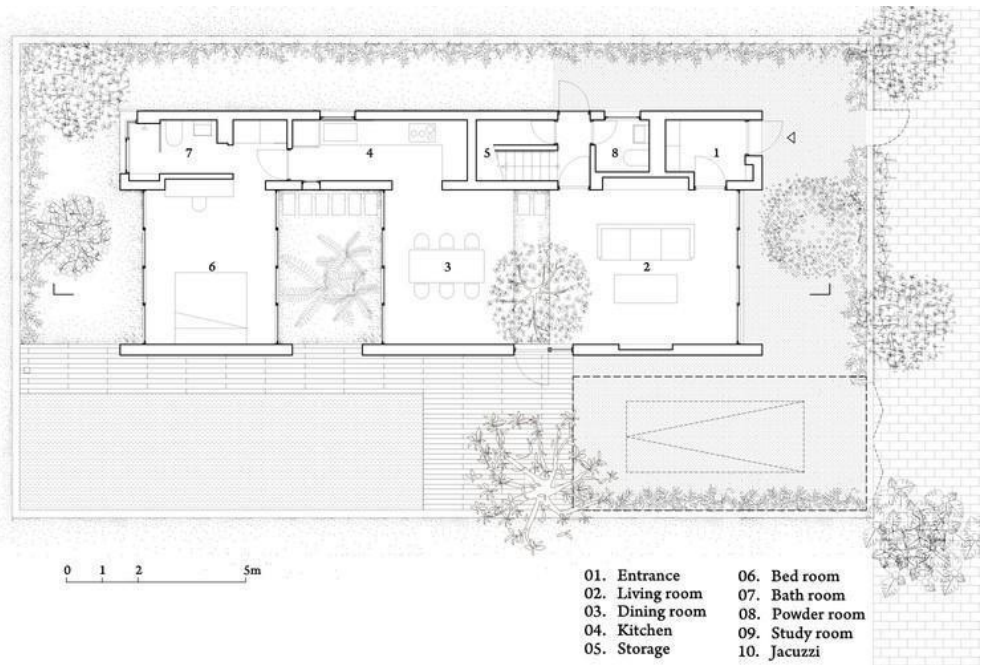

Figura 24. Planta baixa térreo.

Fonte: https://bit.ly/2PrBZRu, acessado em 17/10/2017. 


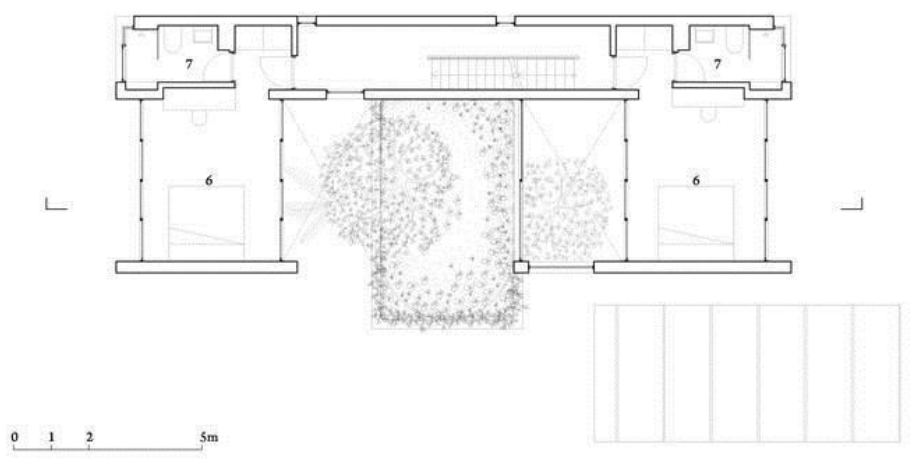

Figura 25. Planta baixa 10 pav.

Fonte: https://bit.ly/2PrBZRu, acessado em 17/10/2017.

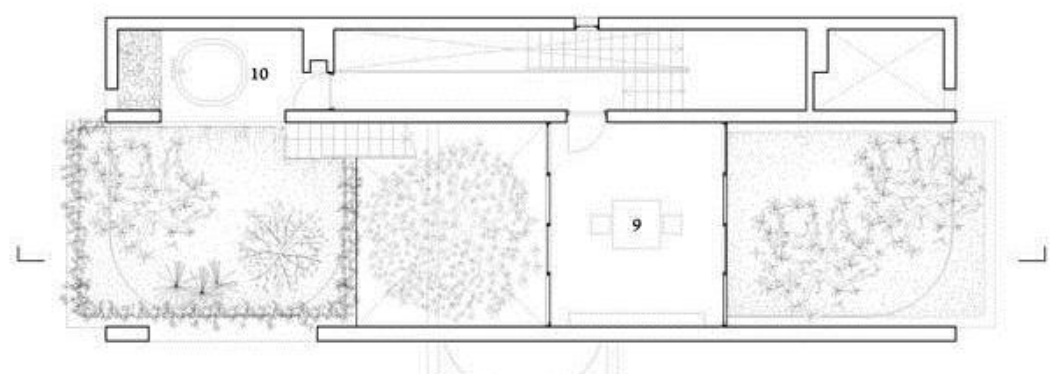

Figura 26. Planta baixa 20 pav..

Fonte: https://bit.ly/2PrBZRu, acessado em 17/10/2017.

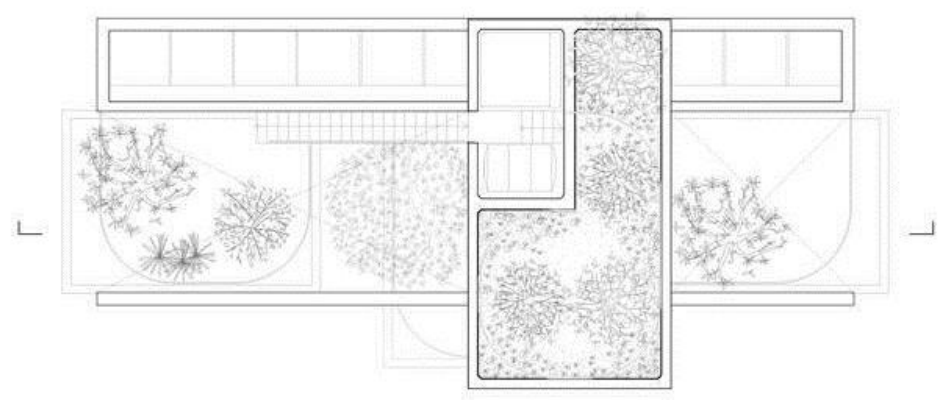

$0 \quad 125 \mathrm{~m}$

Figura 27. Planta terraço.

Fonte: https://bit.ly/2PrBZRu, acessado em 17/10/2017. 
- Residência J2. Arquitetos: Lindvall A \& D. Localização: Falsterbo, Suécia. Autor: Jonas Lindvall. Área: 260.0 m2. Ano do projeto: 2013 (Figuras 28 a 33).

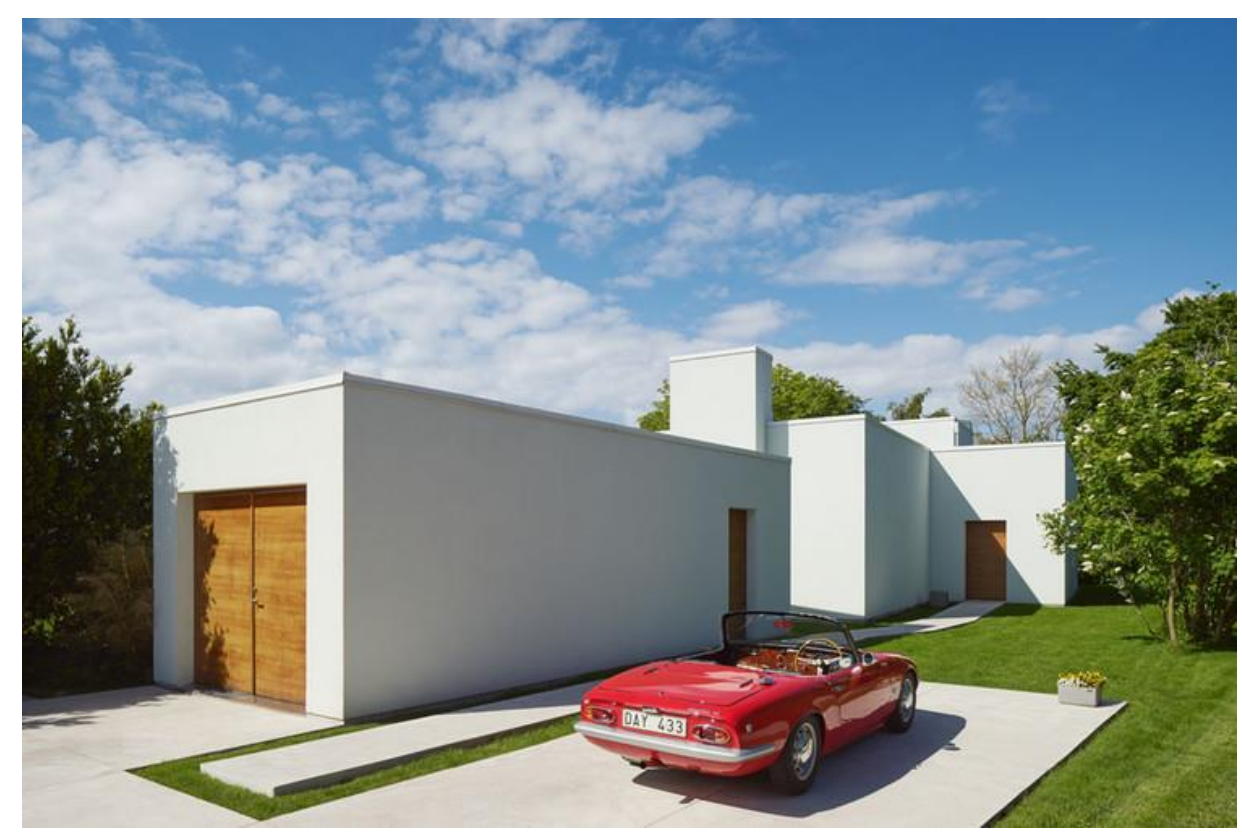

Figura 28. Perspectiva externa.

Fonte: https://bit.ly/2w3kQFr, acessado em 22/10/2017.

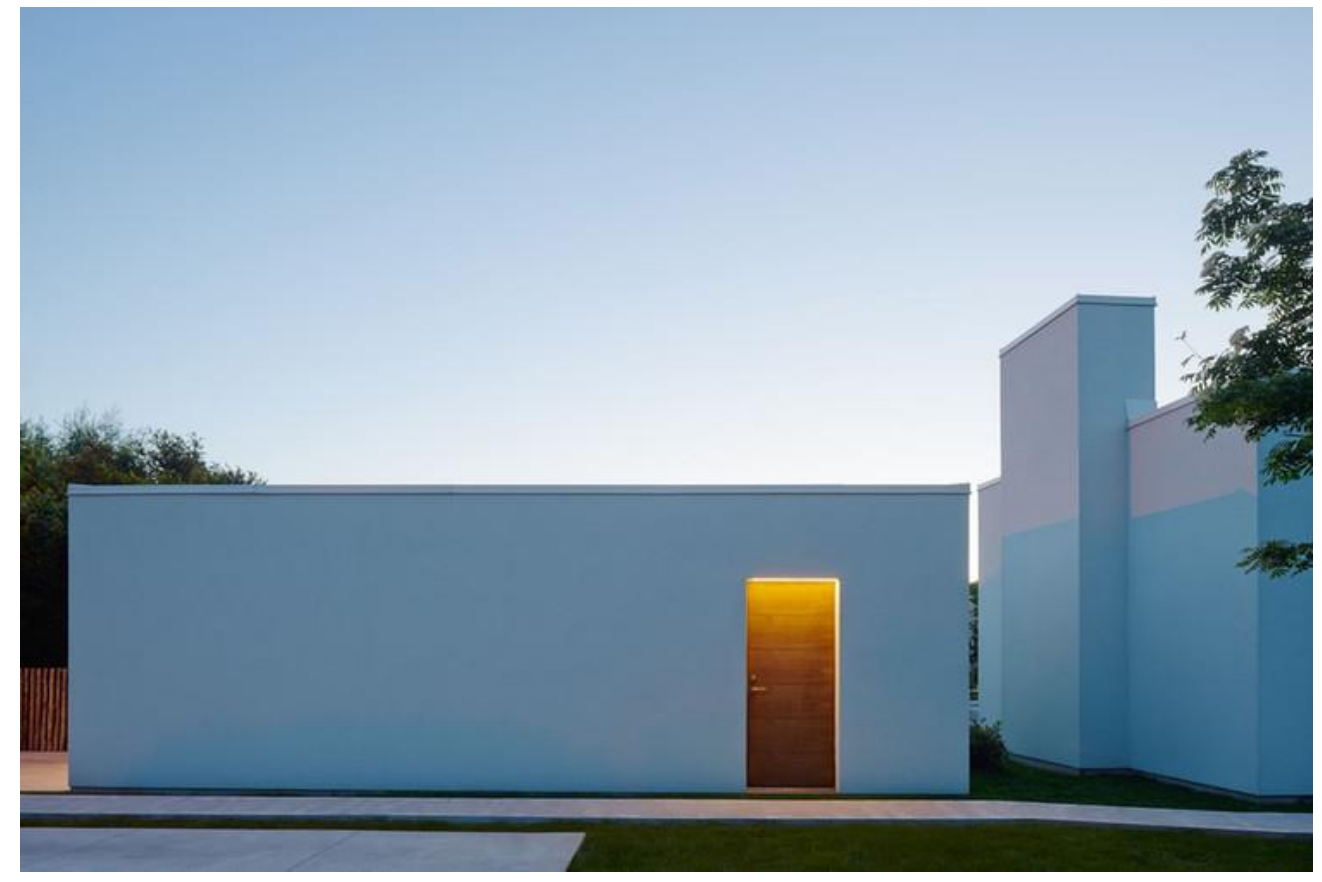

Figura 29. Perspectiva externa.

Fonte: https://bit.ly/2w3kQFr, acessado em 22/10/2017. 

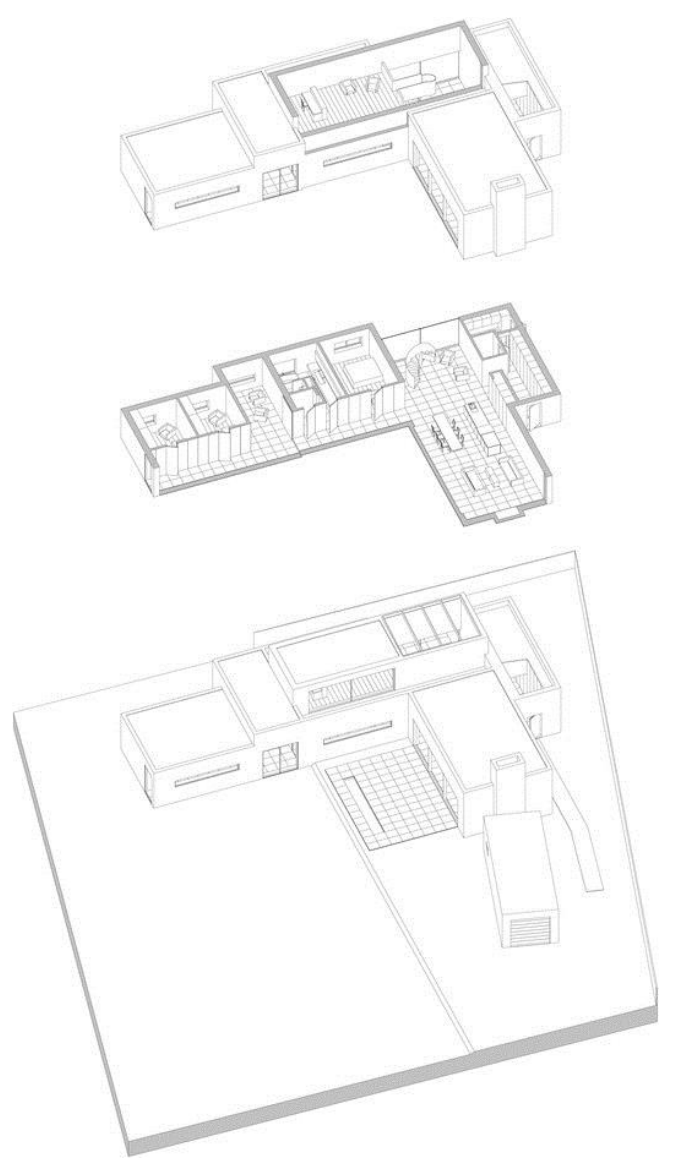

Figura 30. Perspectiva.

Fonte: https://bit.ly/2w3kQFr, acessado em 22/10/2017.

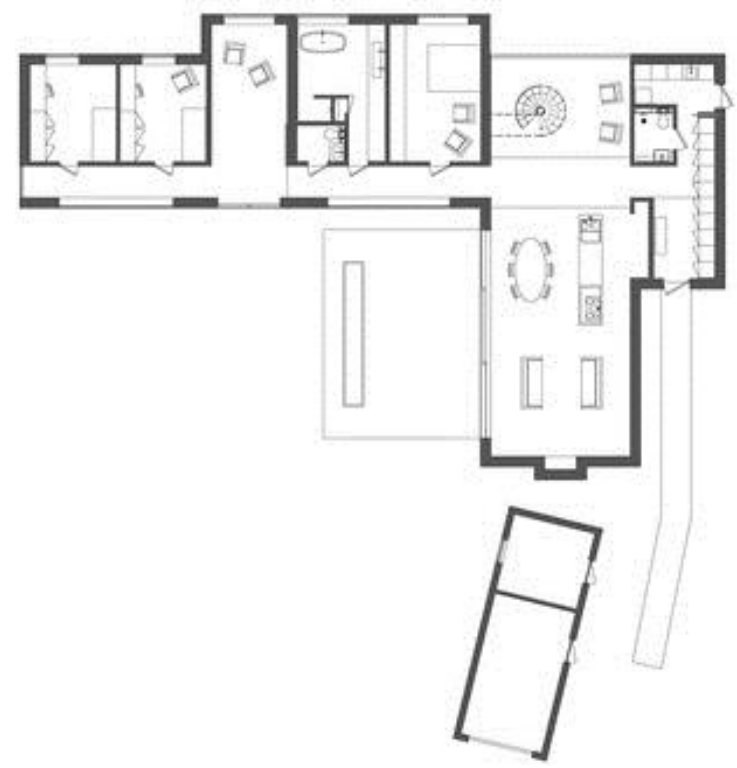

Figura 31. Perspectiva interna.

Fonte: https://bit.ly/2w3kQFr, acessado em 22/10/2017. 

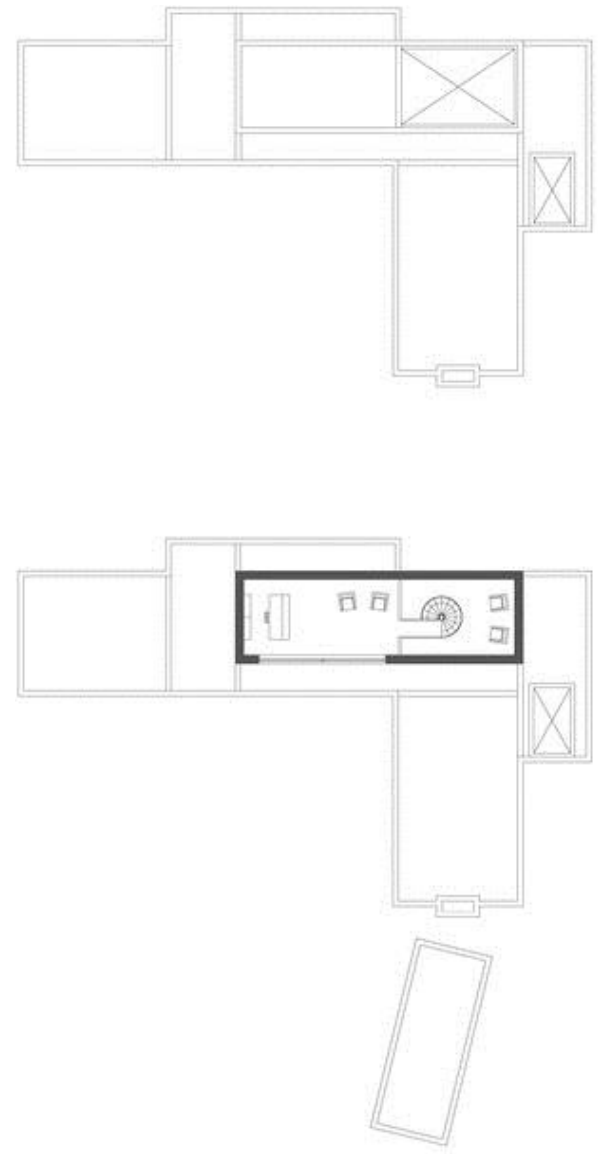

Figura 32. Perspectiva interna.

Fonte: https://bit.ly/2w3kQFr, acessado em 22/10/2017.
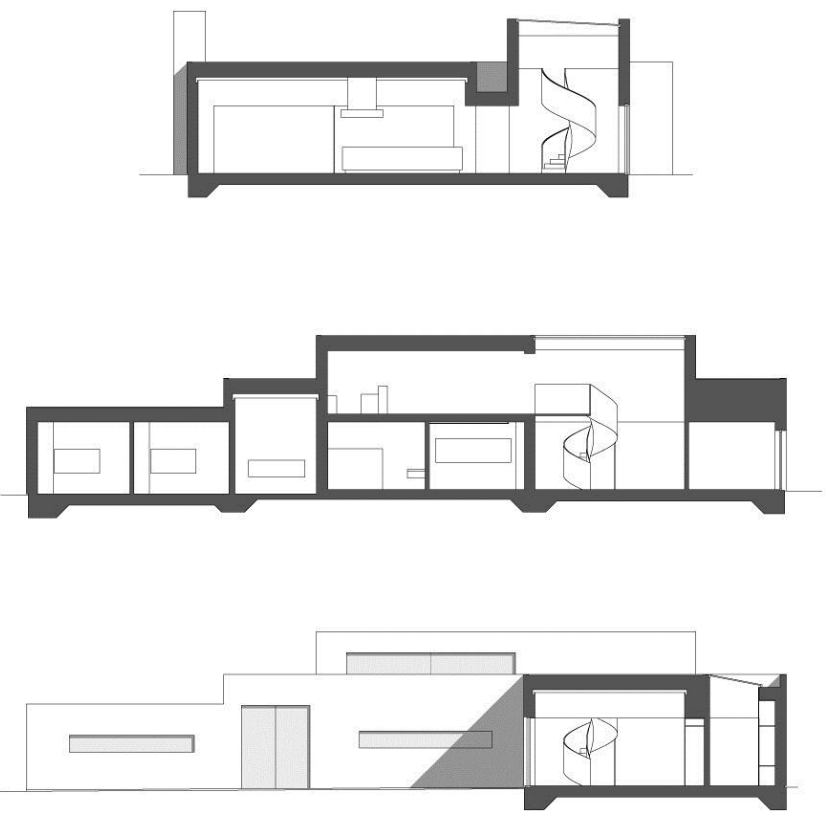

Figura 33. Perspectiva interna.

Fonte: https://bit.ly/2w3kQFr, acessado em 22/10/2017. 
Casa biblioteca. Arquitetos: Shinichi Ogawa \& Associates. Localização: Tochigi, Japão. Área Construída: 163.93 m2. Ano: 2012 (Figuras 34 a 37).

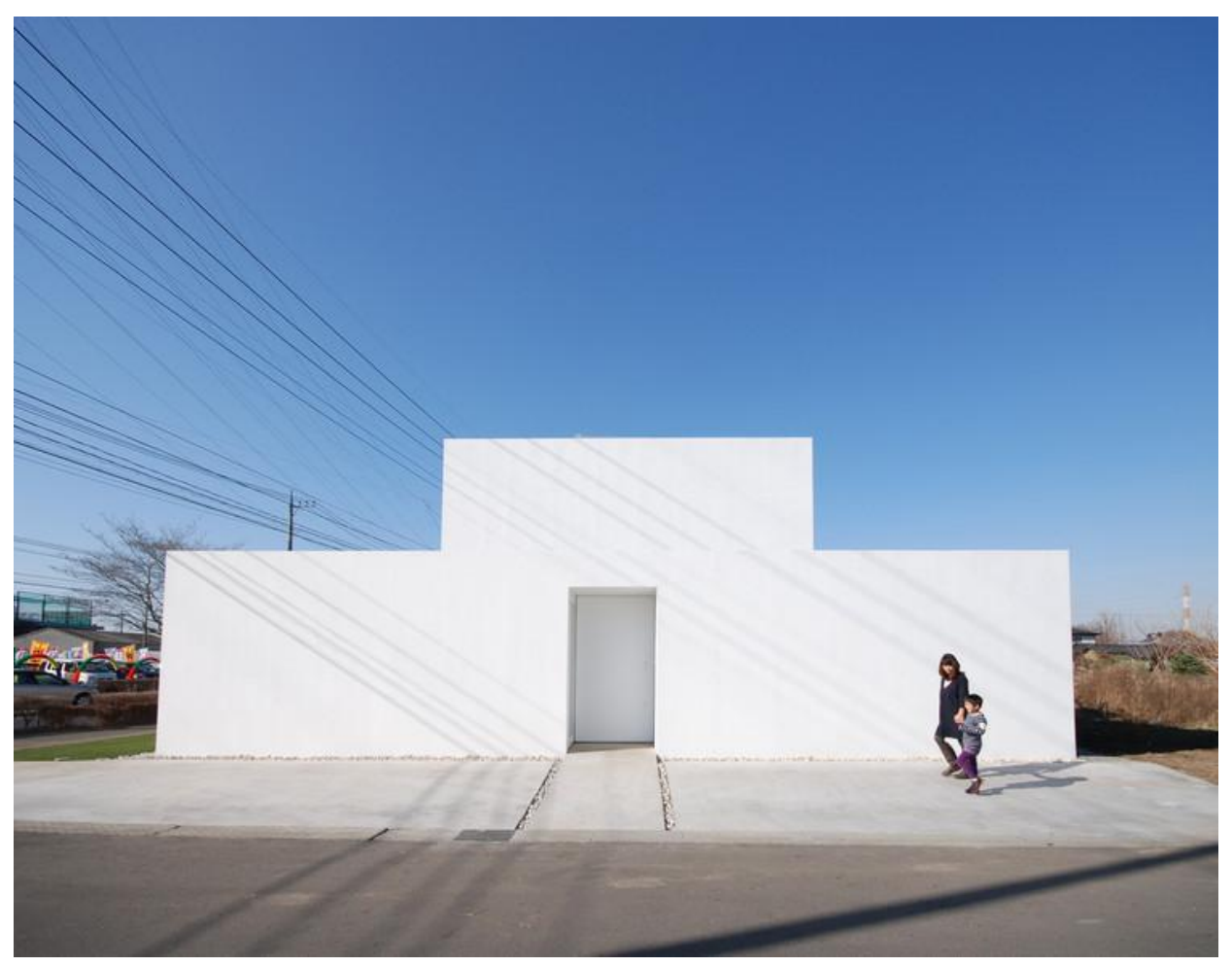

Figura 34. Fachada principal.

Fonte: https://bit.ly/20W6s97, acessado em 22/10/2017.

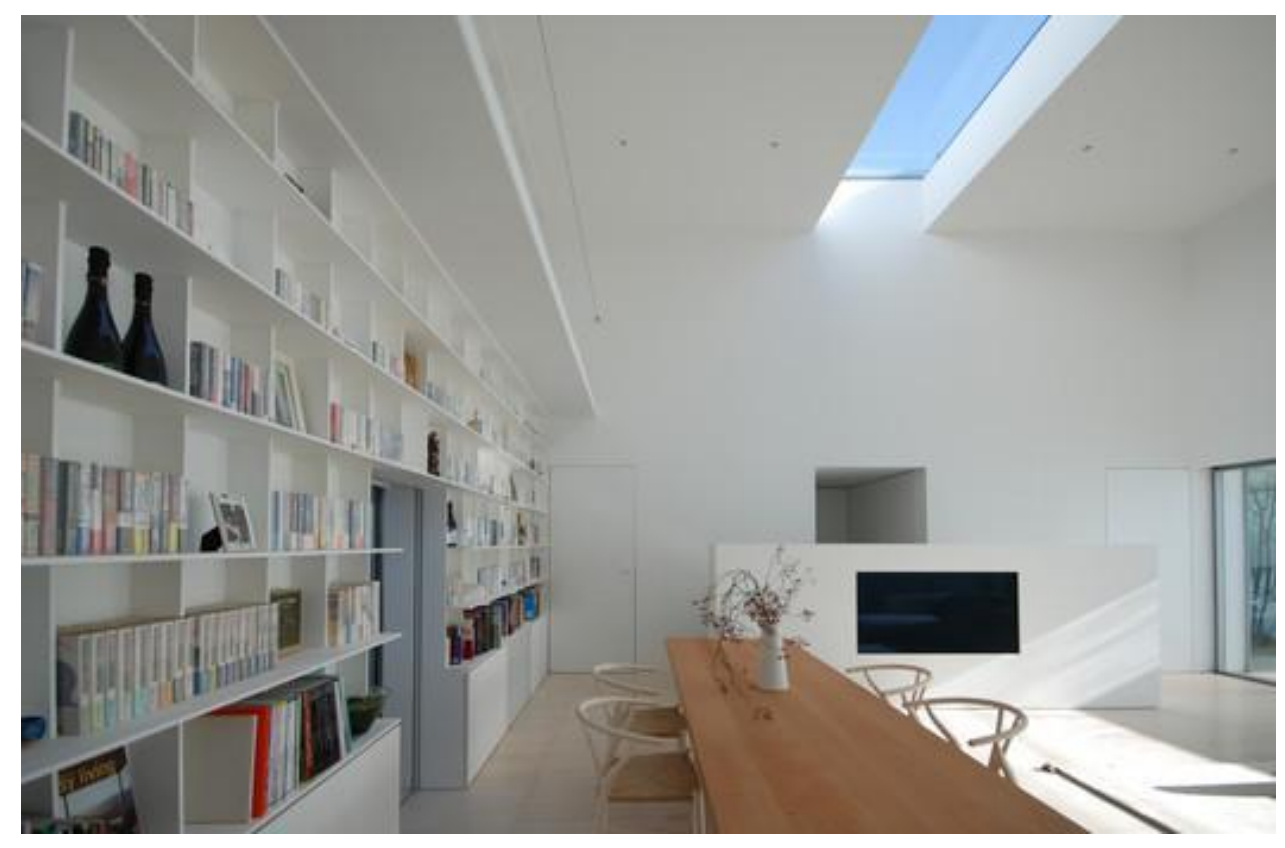

Figura 35. Perspectiva interna.

Fonte: Fonte: https://bit.ly/20W6s97, acessado em 22/10/2017. 


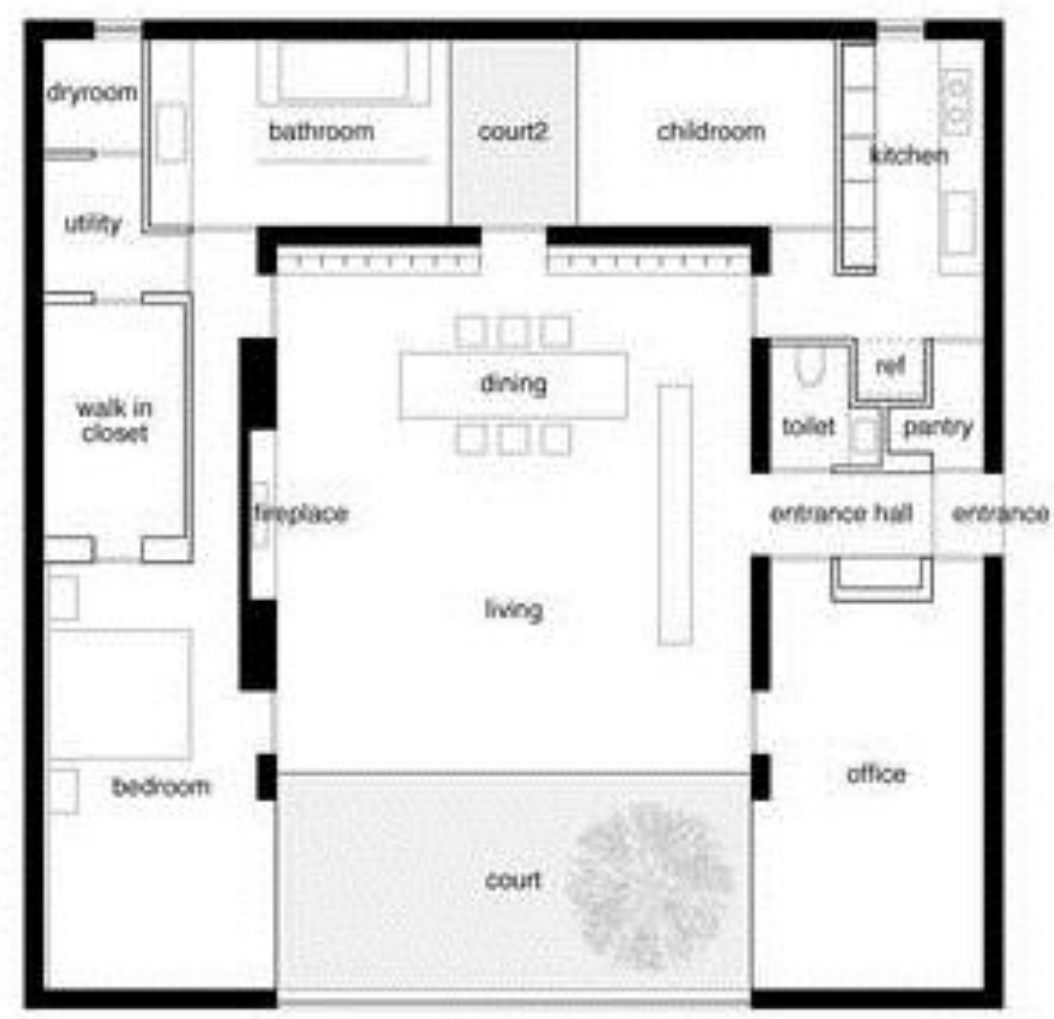

Figura 36. Planta baixa.

Fonte: Fonte: https://bit.ly/20W6s97, acessado em 22/10/2017.

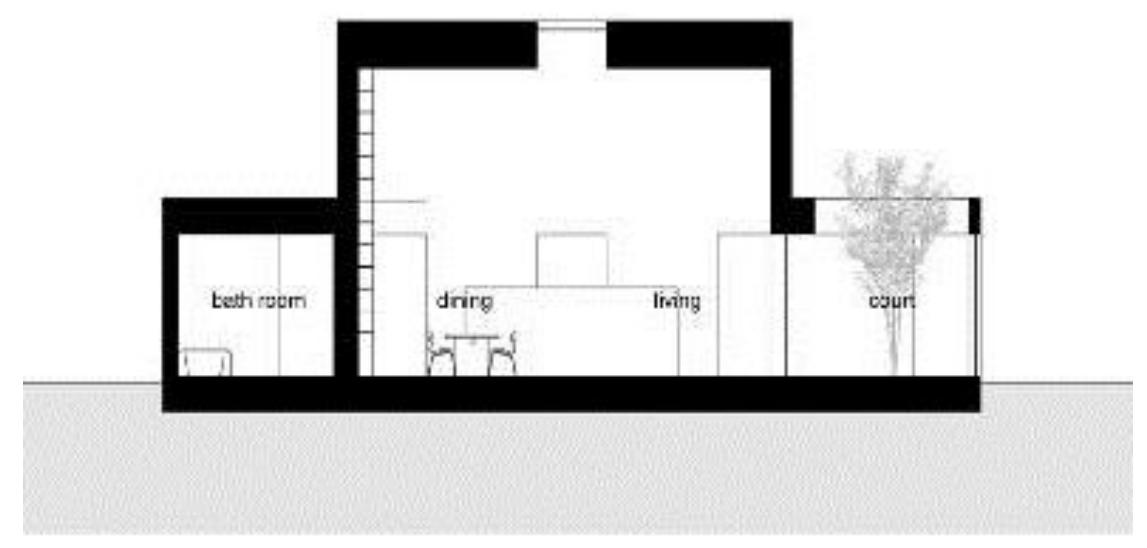

Figura 37. Corte.

Fonte: https://bit.ly/20W6s97, acessado em 22/10/2017. 
Residência Cl336. Arquitetos: Gonzalo Bardach - Matias Mosquera. Localização: San Isidro, Argentina. Área: 250.0 m2. Ano do projeto: 2016 (Figuras 38 a 45).

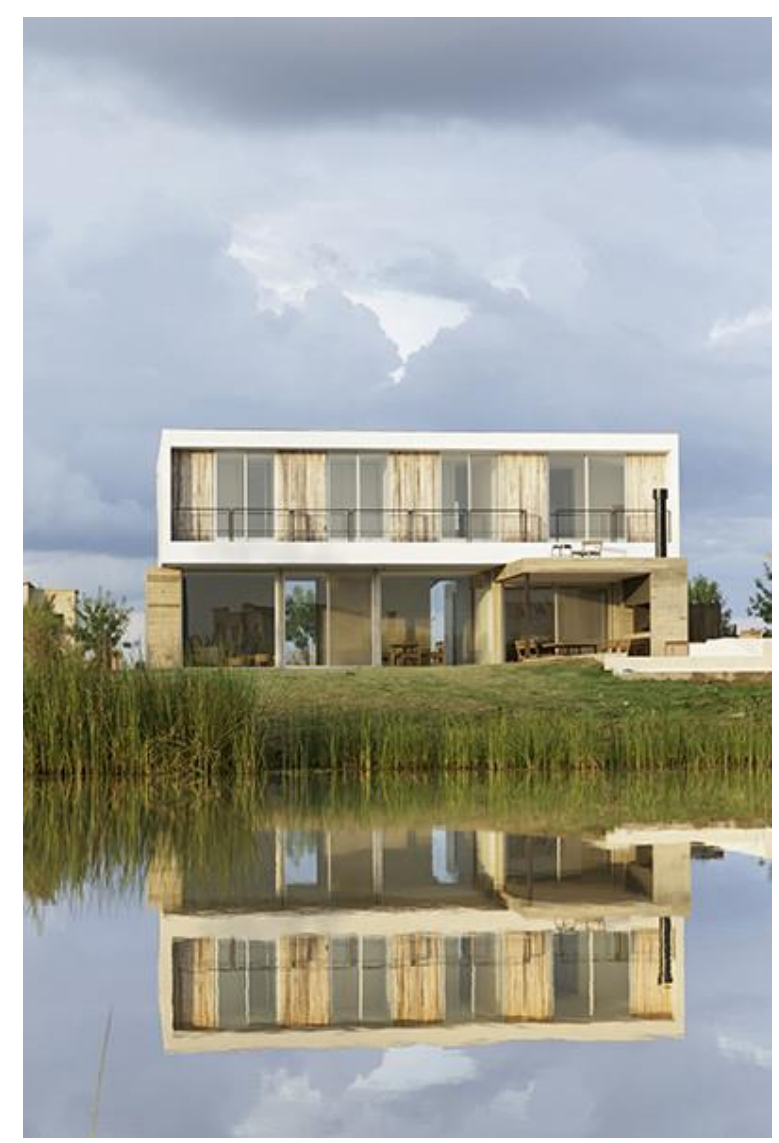

Figura 38. Perspectiva externa.

Fonte: https://bit.ly/2Ppx17H., acessado em 02/11/2017.

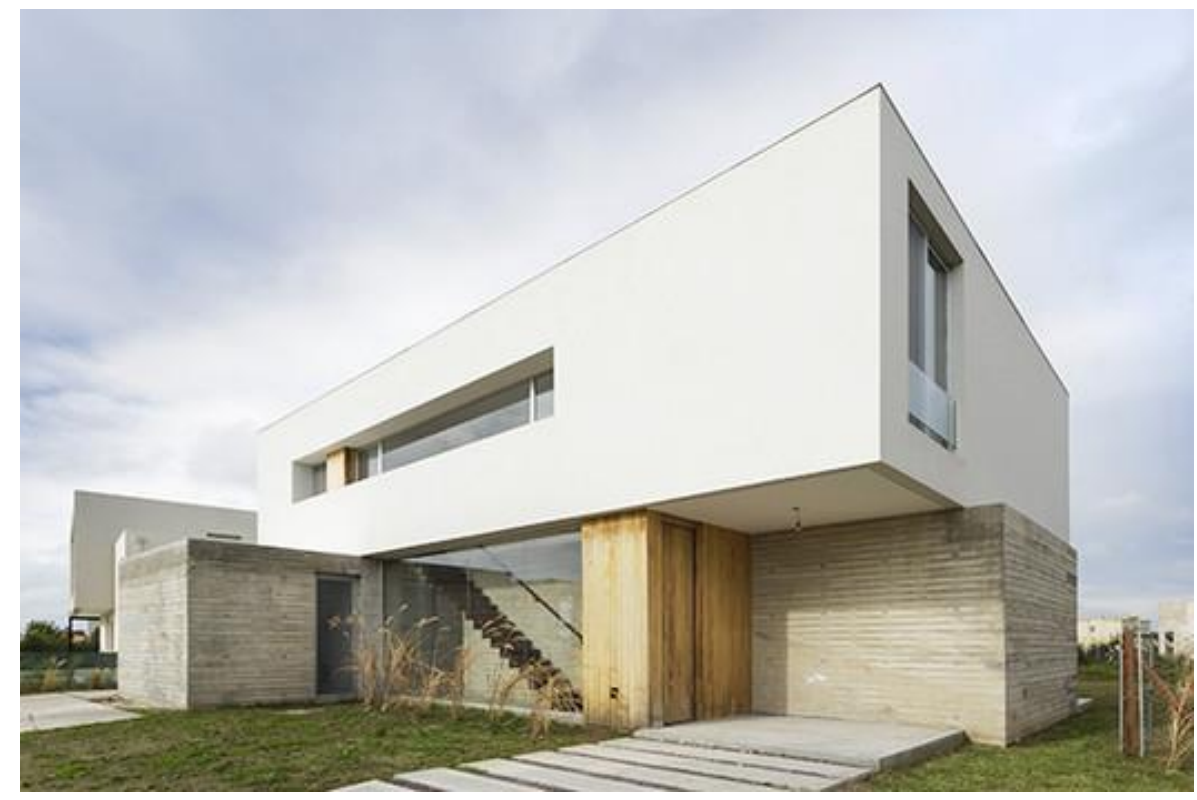

Figura 39. Perspectiva externa.

Fonte: https://bit.ly/2Ppx17H., acessado em 02/11/2017. 


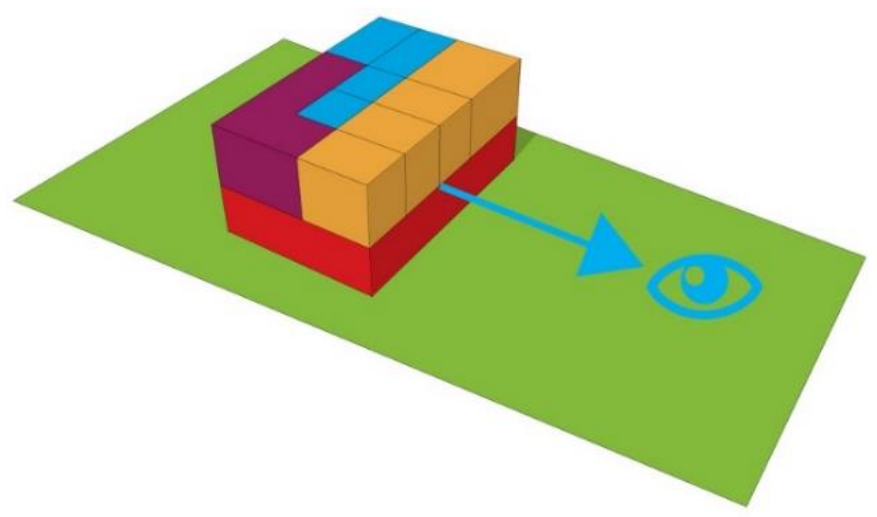

Figura 40. Diagrama 1.

Fonte: https://bit.ly/2Ppx17H., acessado em 02/11/2017.

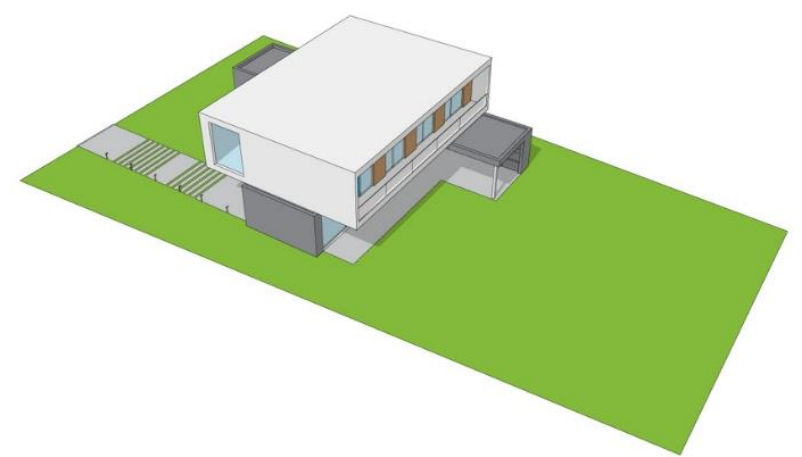

Figura 41. Diagrama 2.

Fonte: https://bit.ly/2Ppx17H., acessado em 02/11/2017.

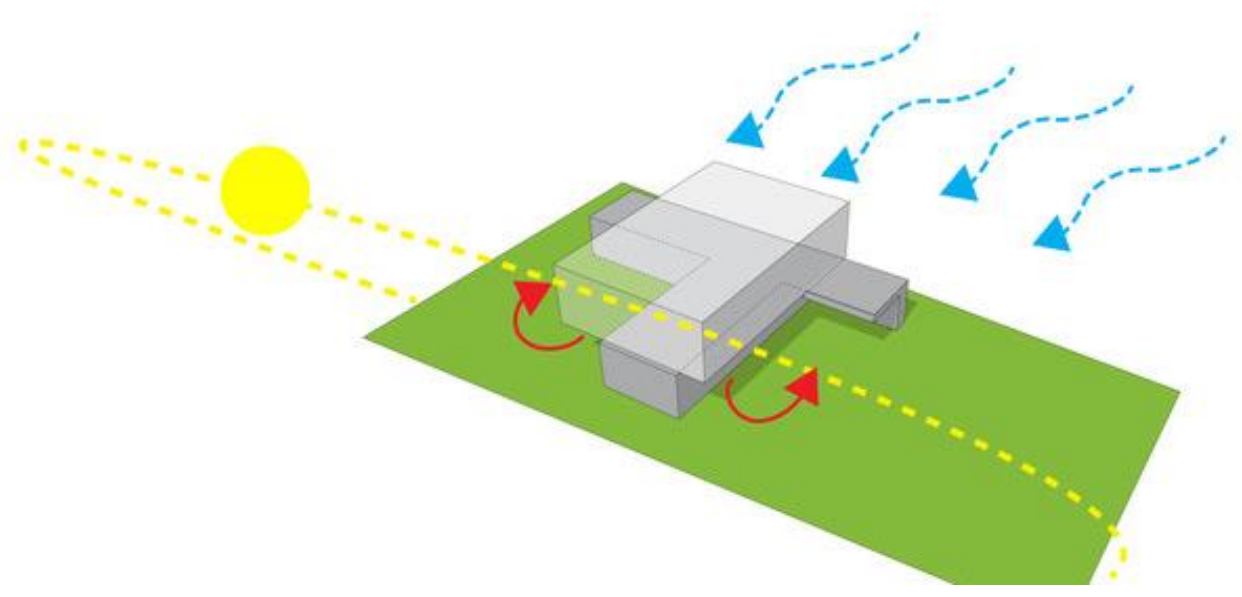

Figura 42. Diagrama de condicionantes.

Fonte: https://bit.ly/2Ppx17H., acessado em 02/11/2017. 


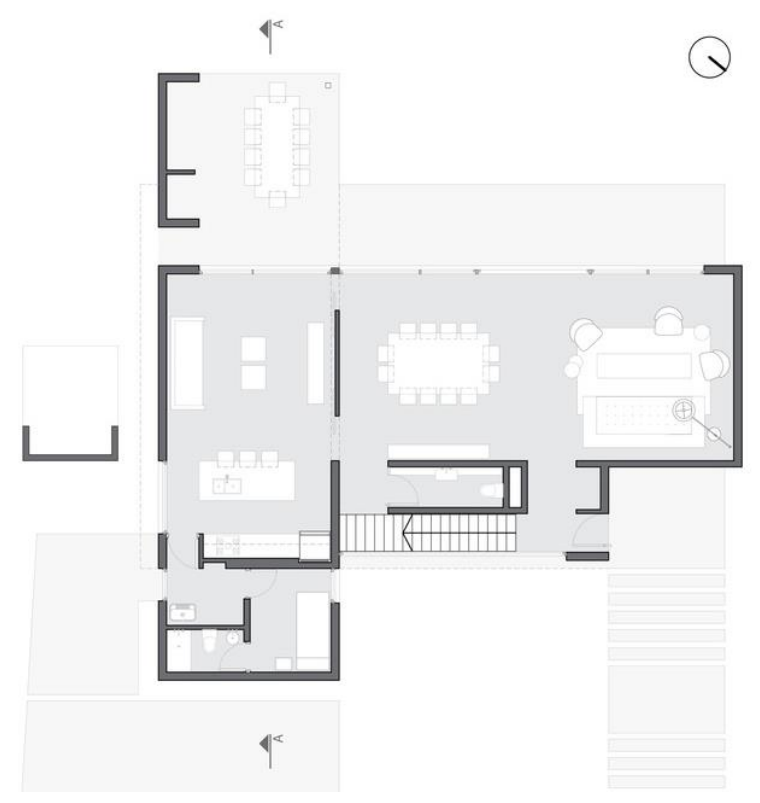

Figura 43. Planta baixa térreo.

Fonte: https://bit.ly/2Ppx17H., acessado em 02/11/2017.

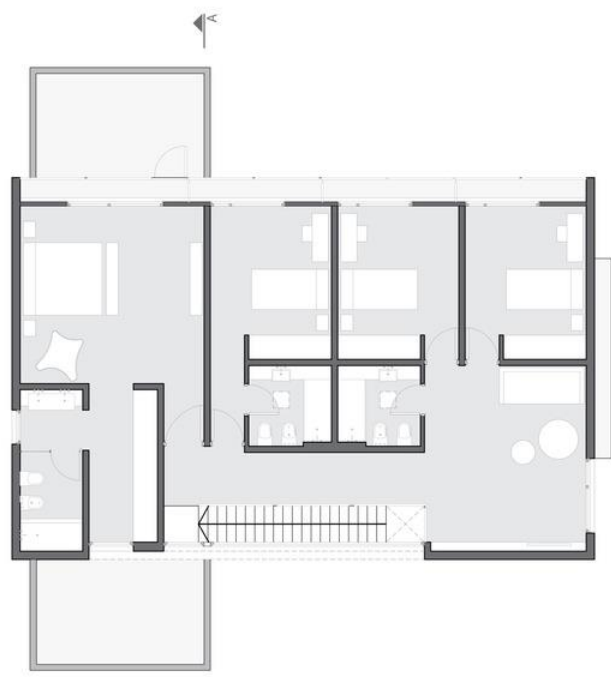

Figura 44. Planta baixa pav. superior.

Fonte: https://bit.ly/2Ppx17H., acessado em 02/11/2017.

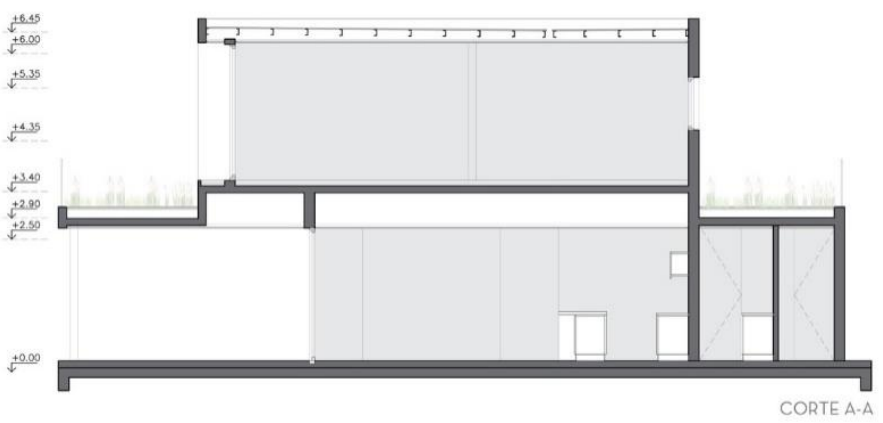

Figura 45. Corte.

Fonte: https://bit.ly/2Ppx17H., acessado em 02/11/2017. 
Casa Pátio. Arquitetos: Seinfeld Arquitectos. Localização: San Isidro, Peru. Arquiteto responsável: Cynthia Seinfeld. Colaborador: Martín Zavaleta. Terreno: 517 m2. Área: 540.0 m2. Ano Projeto: 2008(Figuras 46 a 51).

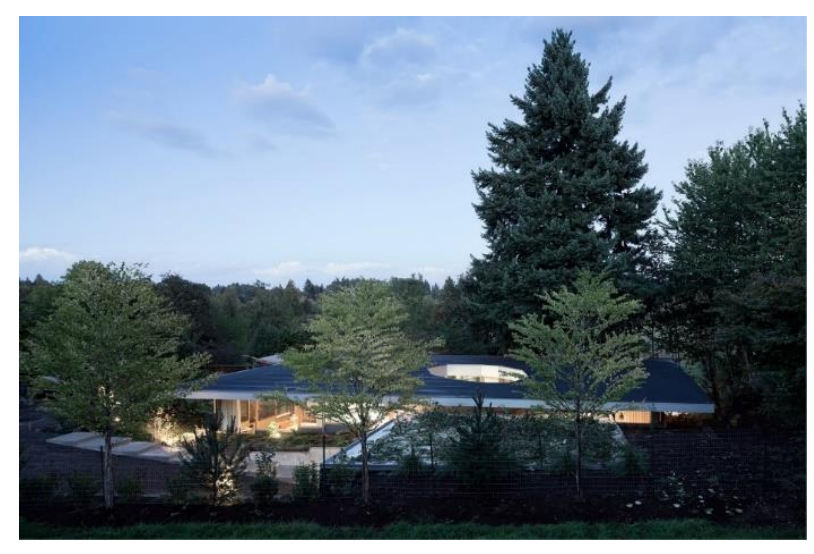

Figura 46. Perspectiva externa.

Fonte: https://bit.ly/2MtzhwY. acessado em 02/11/2017.

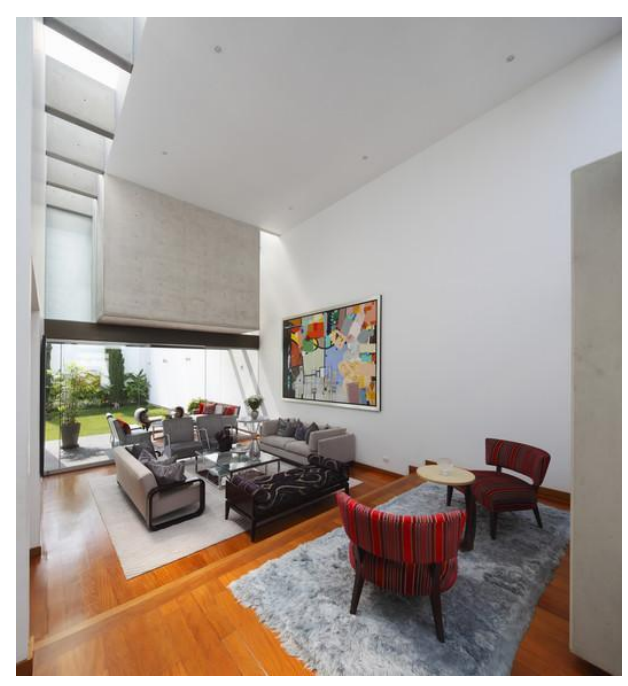

Figura 47. Perspectiva interna.

Fonte: https://bit.ly/2MtzhwY., acessado em 02/11/2017.

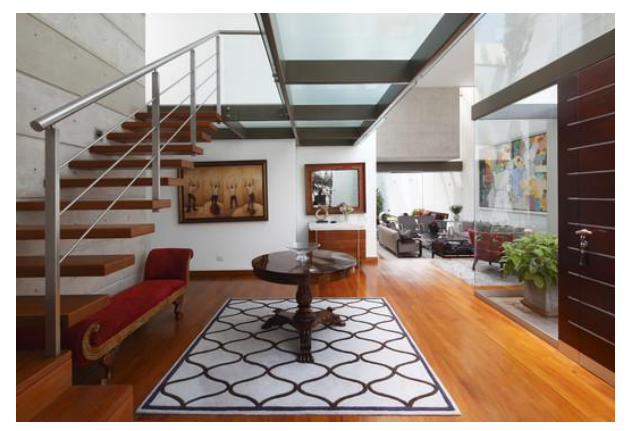

Figura 48. Perspectiva interna.

Fonte: https://bit.ly/2MtzhwY., acessado em 02/11/2017. 


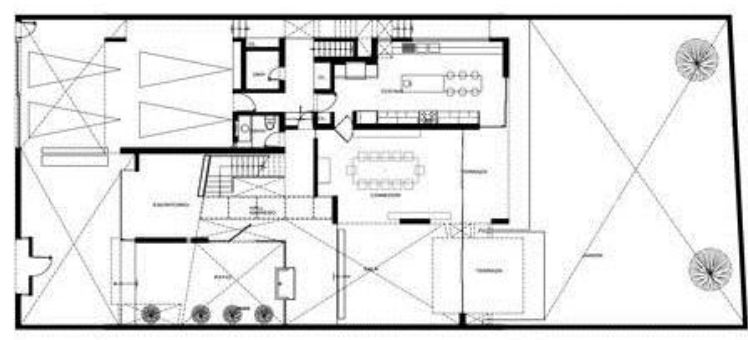

PUANTA PRIMER NNEL

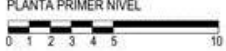

Figura 49. Planta baixa 1o Nível.

Fonte: https://bit.ly/2MtzhwY., acessado em 02/11/2017.

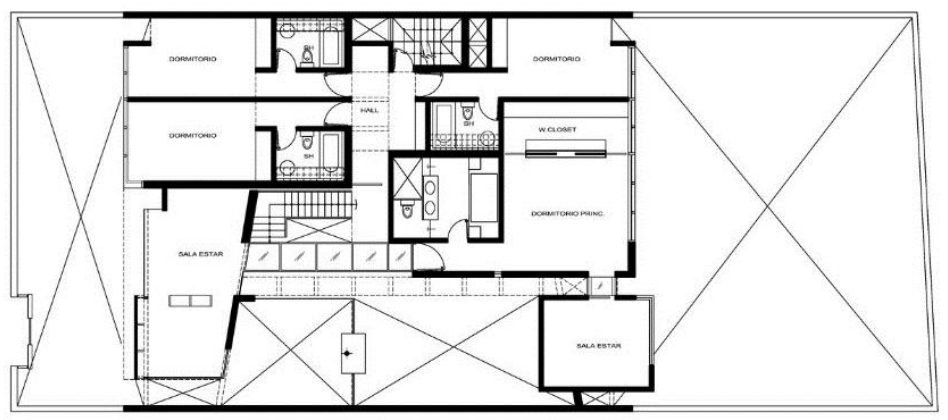

PLANTA SEGUNDO NIVEL

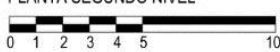

Figura 50. Planta baixa 2을 Nel.

Fonte: https://bit.ly/2MtzhwY., acessado em 02/11/2017.

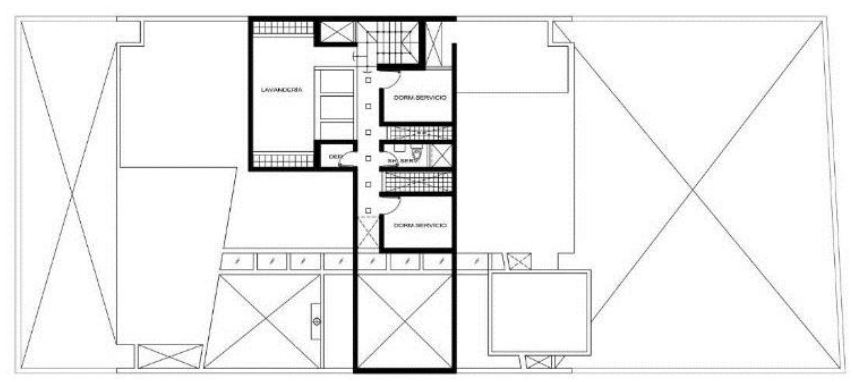

PLANTA TERCER NIVEL

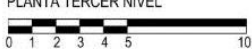

Figura 51. Planta baixa 3을. Nel.

Fonte: https://bit.ly/2MtzhwY., acessado em 02/11/2017. 

de Projeto: Puneeth Hegde, Mithila Manolkar. Área: $2290.0 \mathrm{ft} 2$. Ano do projeto: 2017 (Figuras 52 a 59).

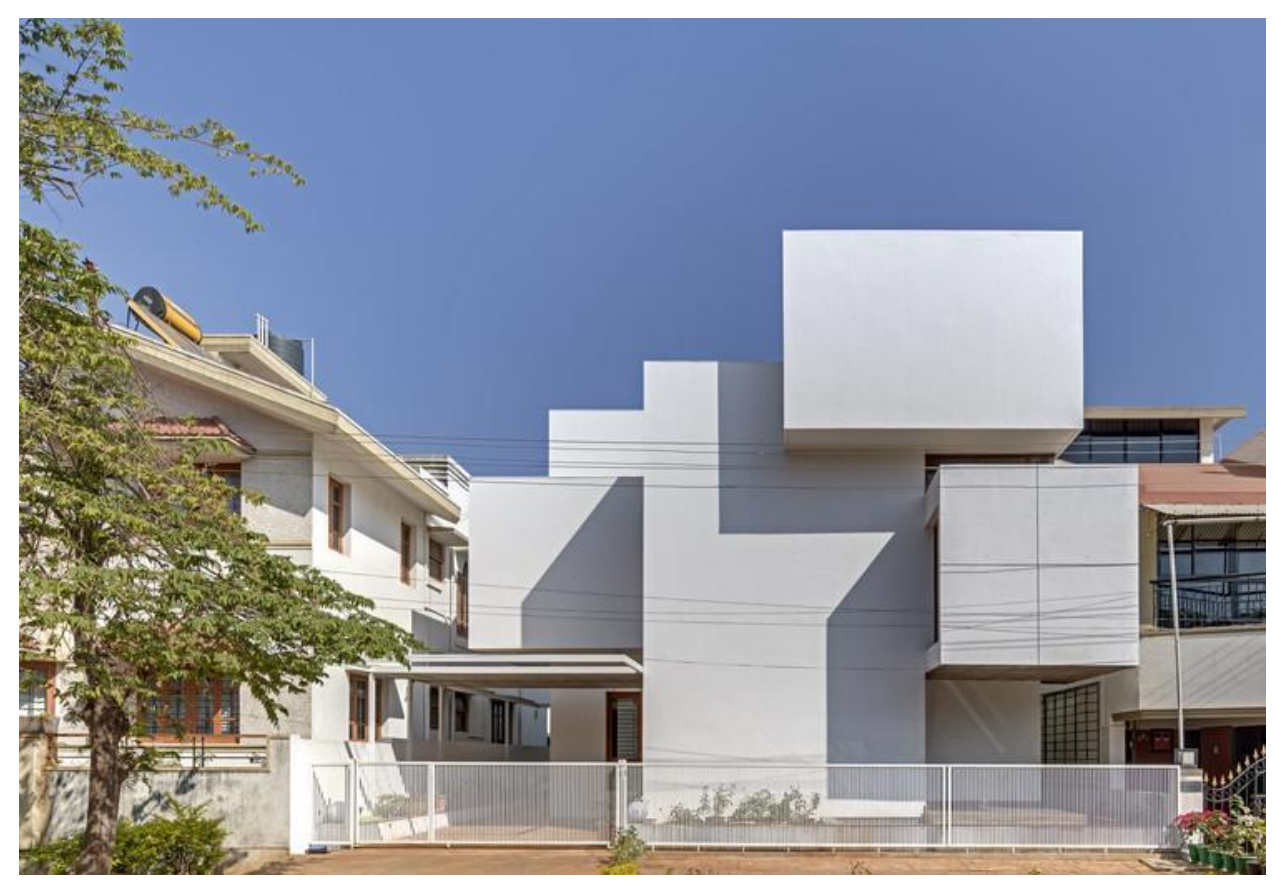

Figura 52. Perspectiva interna.

Fonte: https://bit.ly/2PpxQgN, acessado em 02/11/2017.

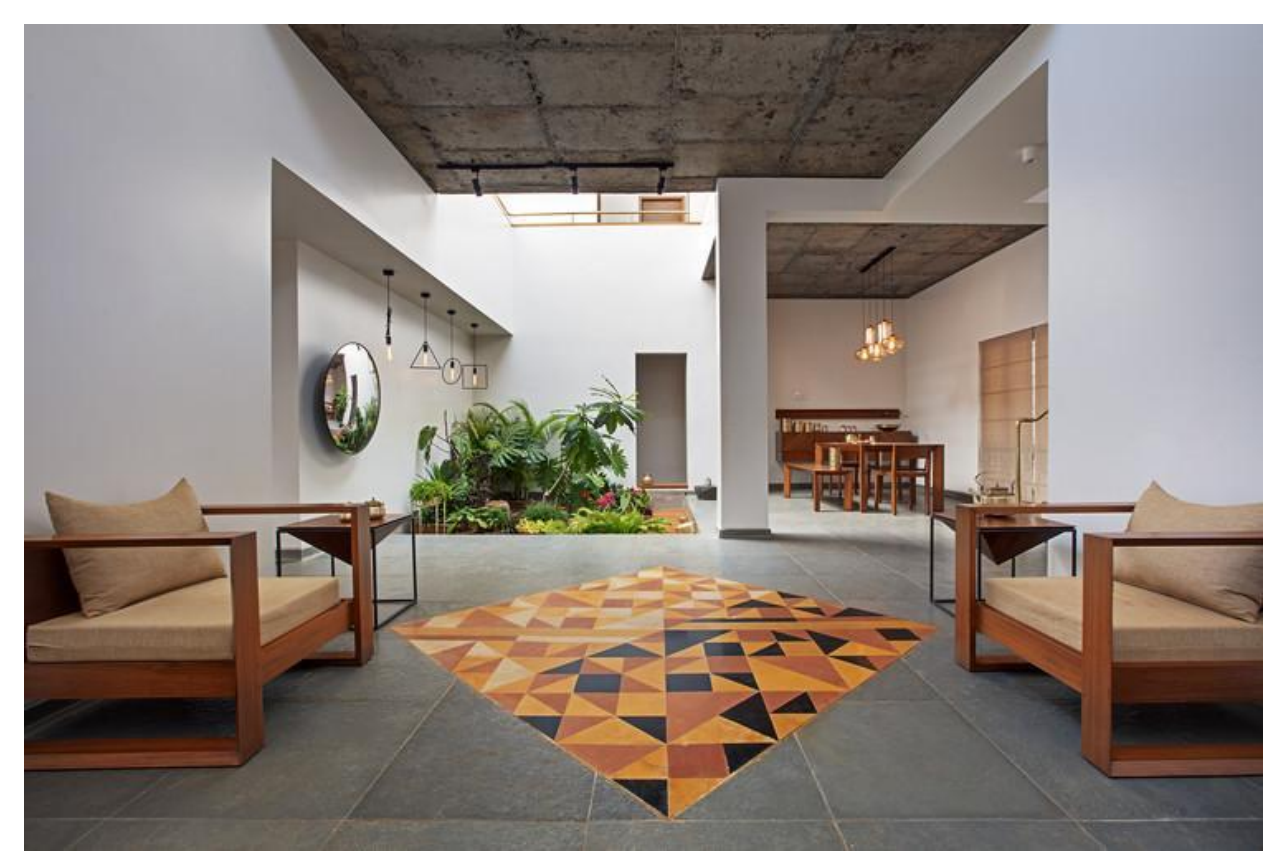

Figura 53. Perspectiva interna.

Fonte: https://bit.ly/2PpxQgN, acessado em 02/11/2017. 


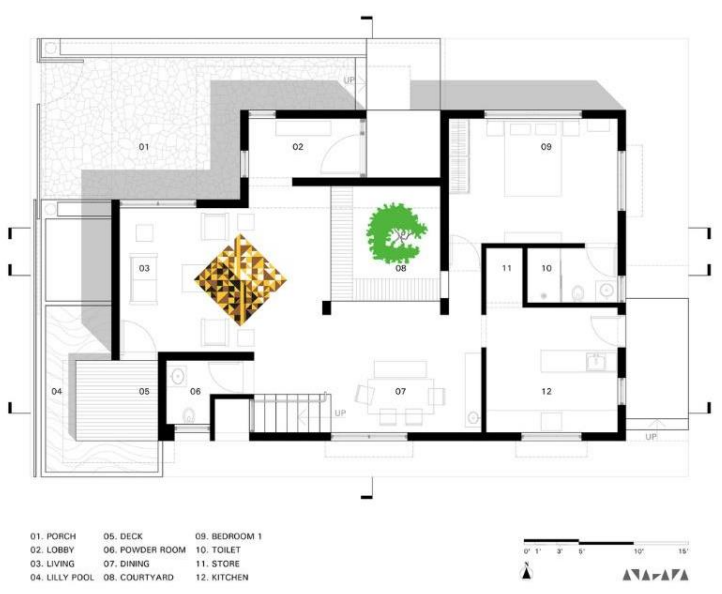

Figura 54. Planta baixa térreo.

Fonte: https://bit.ly/2PpxQgN, acessado em 02/11/2017.
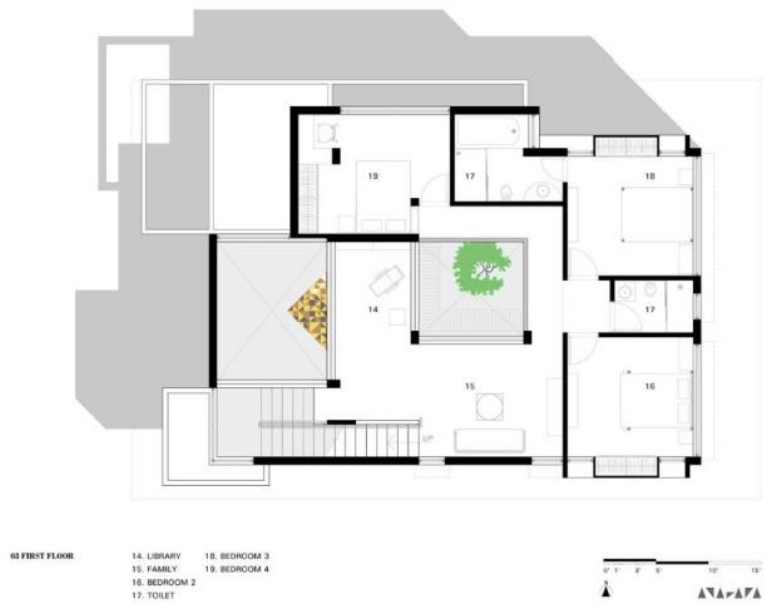

Figura 55. Planta baixa 20 pav.

Fonte: https://bit.ly/2PpxQgN, acessado em 02/11/2017.

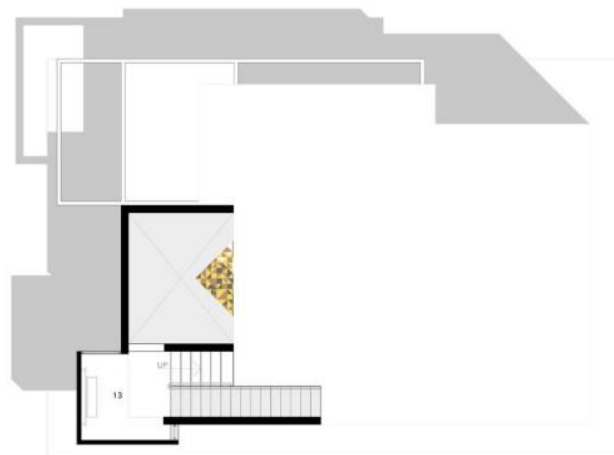

Figura 56. Planta baixa 3 pav.
Fonte: https://bit.ly/2PpxQgN, acessado em 02/11/2017. 


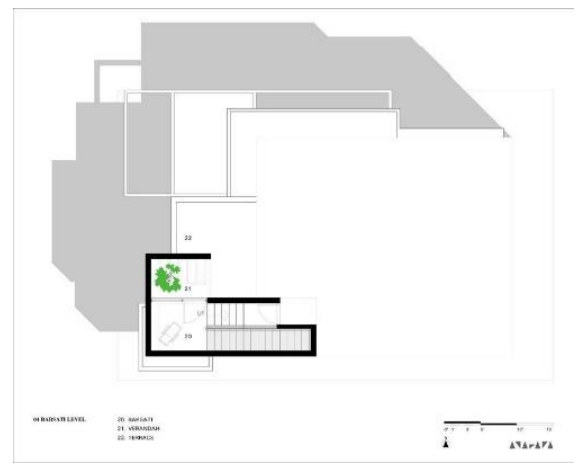

Figura 57. Planta baixa 40 pav.

Fonte: https://bit.ly/2PpxQgN, acessado em 02/11/2017.

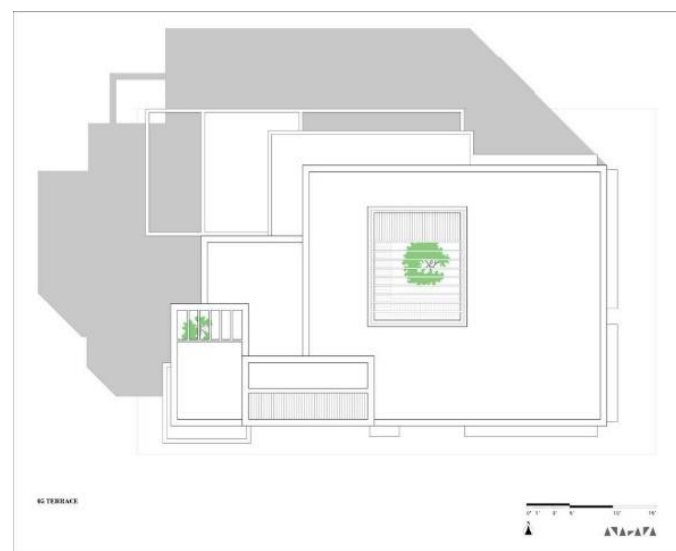

Figura 58. Terraço.

Fonte: https://bit.ly/2PpxQgN, acessado em 02/11/2017.
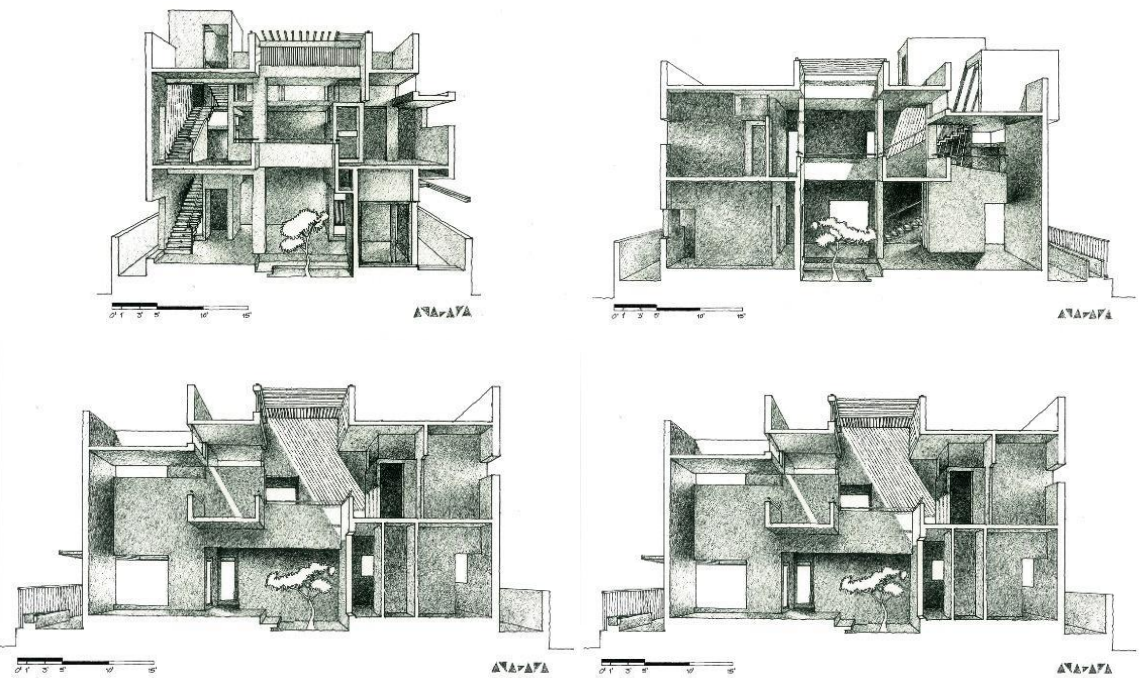

Figura 59. Cortes esquemáticos.

Fonte: https://bit.ly/2PpxQgN, acessado em 02/11/2017. 
- Residência Jonker. Arquitetos: Thomas Gouws Architects.Localização: Pretoria, África do Sul. Arquitetos Responsáveis: Thomas Gouws, Sureen Gouws. Área: $633.0 \mathrm{~m} 2$. Ano do projeto: 2016 (Figuras 60 a 63).

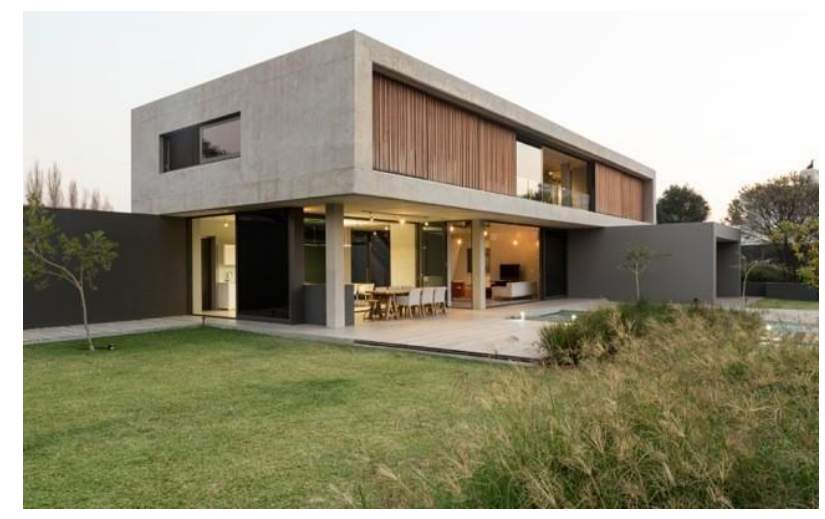

Figura 60. Perspectiva externa.

Fonte: https://bit.ly/2N7aLy, acessado em 02/11/2017.

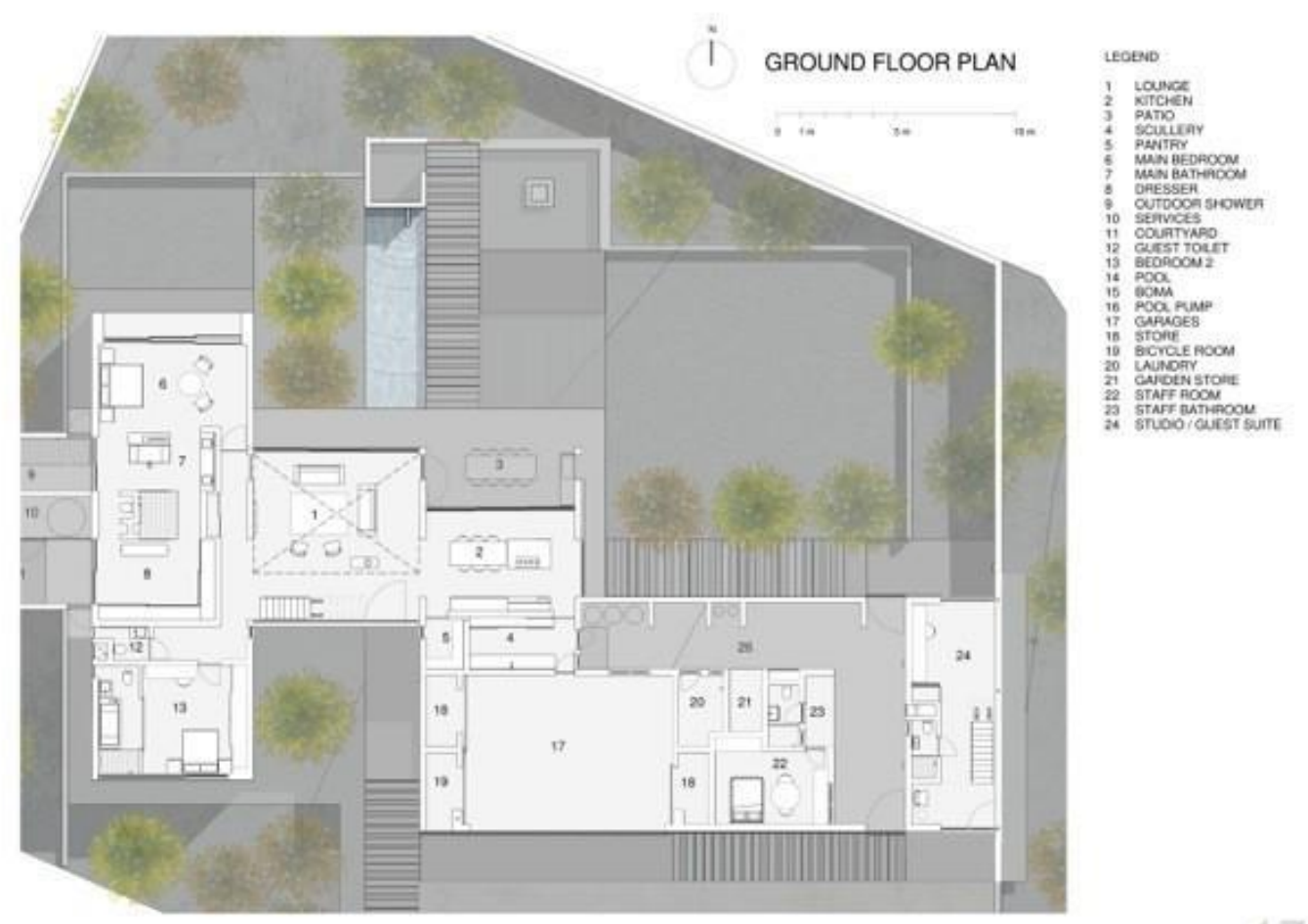

Figura 61. Planta baixa térreo.

Fonte: https://bit.ly/2N7aLy, acessado em 02/11/2017. 


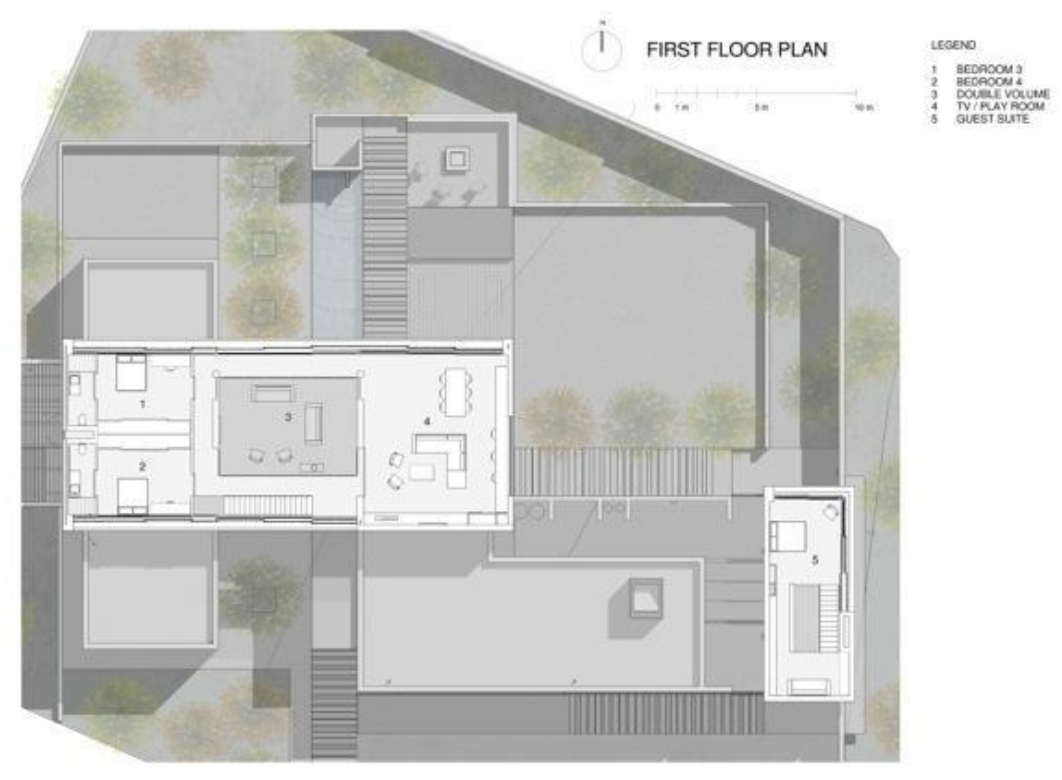

Figura 10. Planta baixa pav. superior.

Fonte: https://bit.ly/2N7aLy, acessado em 02/11/2017.

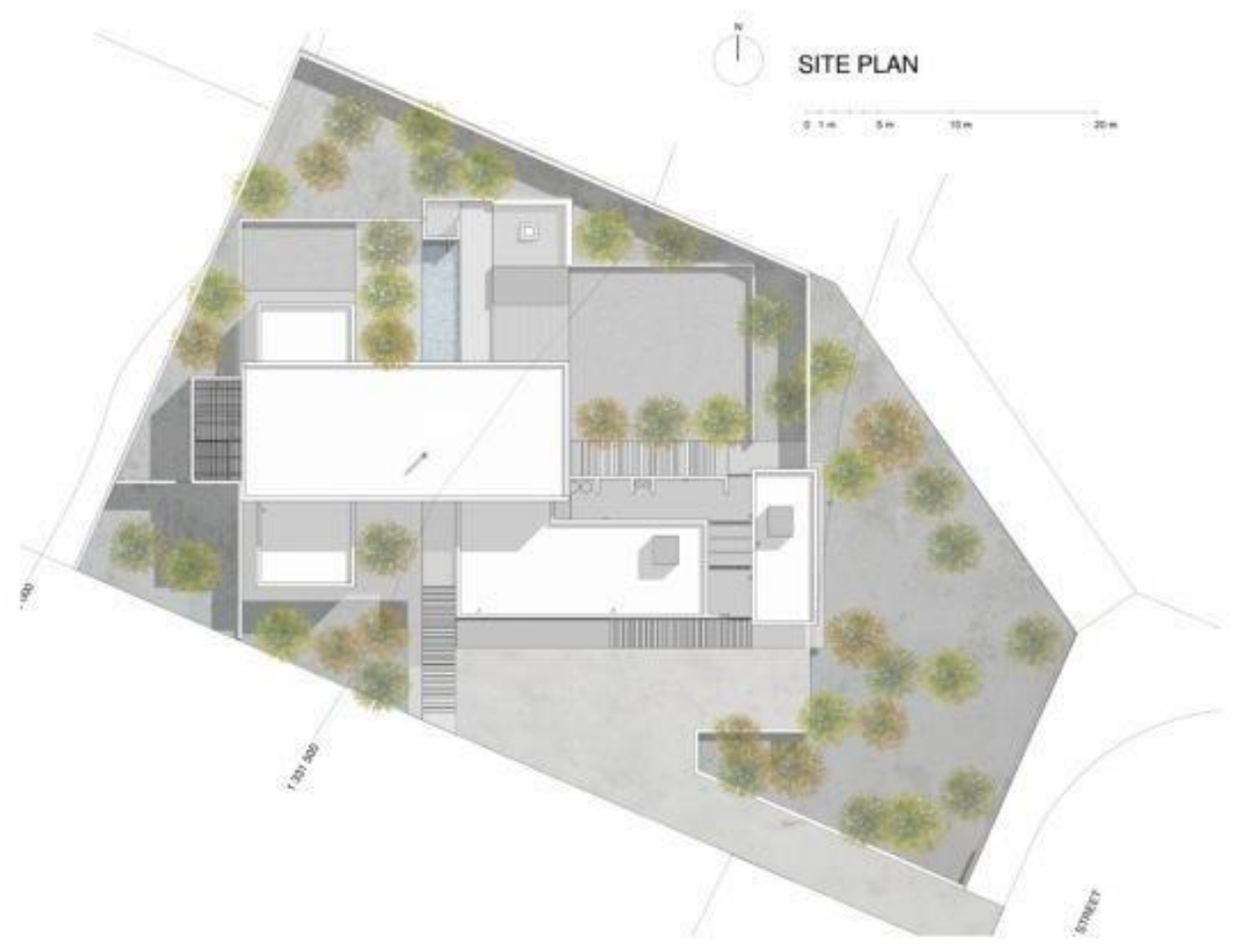

Figura 62. Planta de cobertura.

Fonte: https://bit.ly/2N7aLy, acessado em 02/11/2017. 
Casa Canto do Pescador. Arquitetos: TAAB. Localização: Jacona, México. Autores: Diana G. Ortiz Moreno y Diego Torres Guízar. Área: 295.0 m2. Ano do Projeto: 2016 (Figuras 63 a 67).

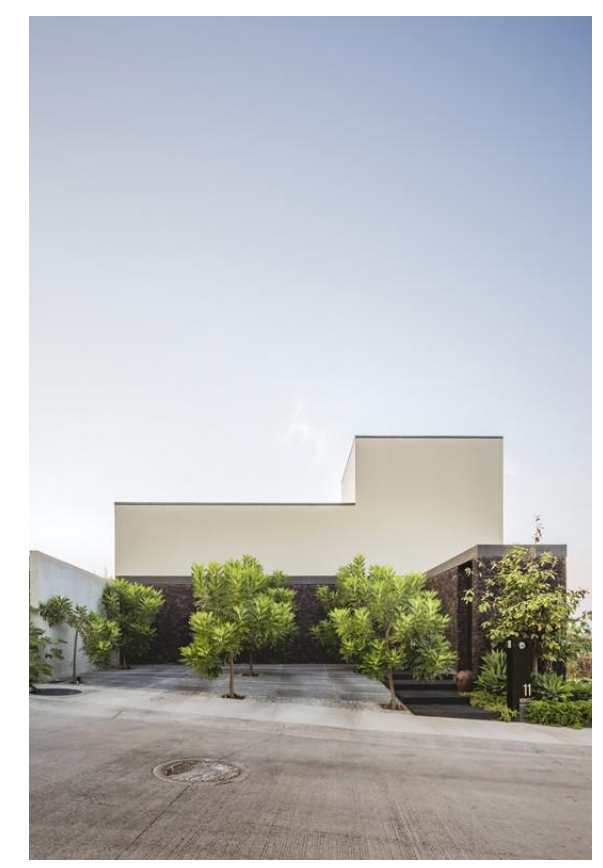

Figura 63. Perspectiva externa frontal. Fonte: https://bit.ly/2N6mcWC, acessado em 02/11/2017.

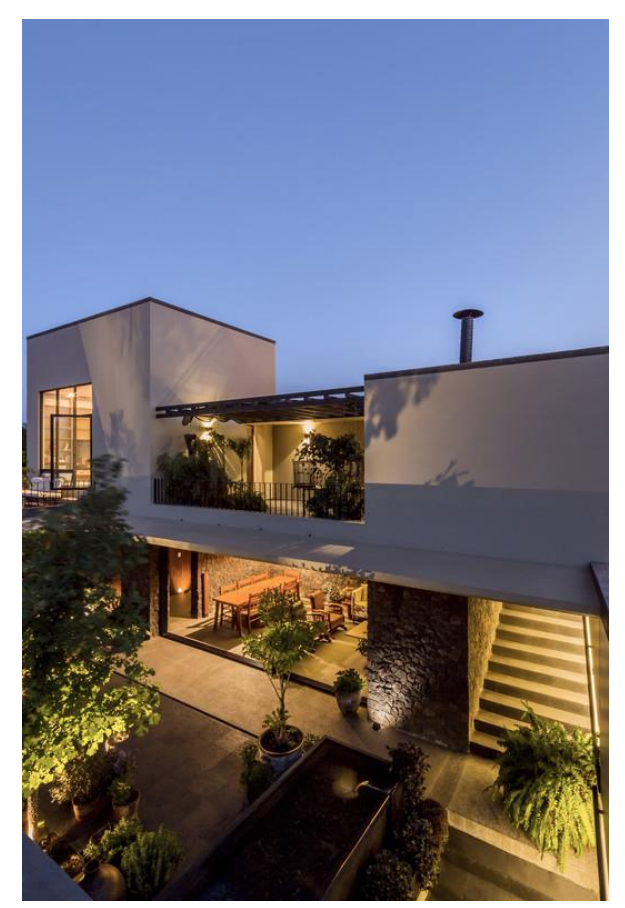

Figura 63. Perspectiva externa posteior. Fonte: https://bit.ly/2N6mcWC, acessado em 02/11/2017. 


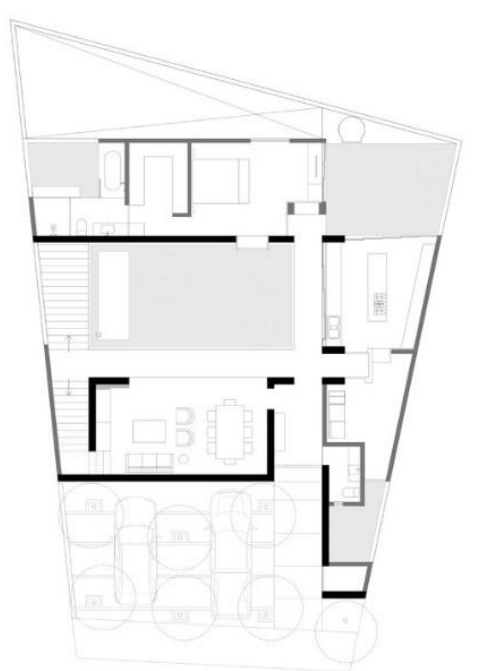

Figura 65. Planta baixa térreo.

Fonte: https://bit.ly/2N6mcWC, acessado em 02/11/2017.

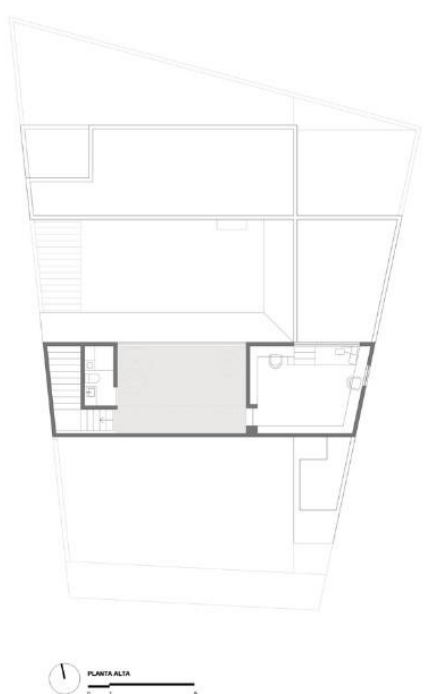

Figura 66. Planta baixa pav. Superior

Fonte: https://bit.ly/2N6mcWC, acessado em 02/11/2017.

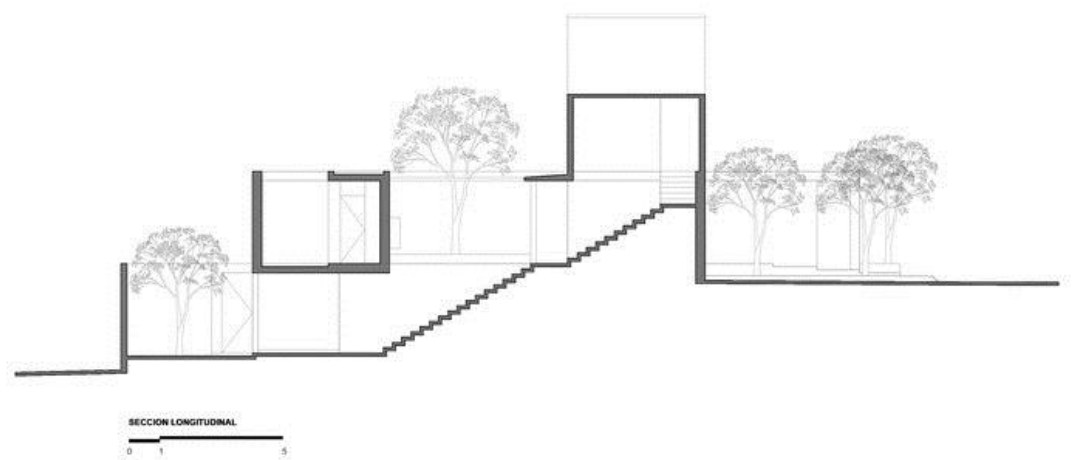

Figura 67. Corte.

Fonte: https://bit.ly/2N6mcWC, acessado em 02/11/2017. 


\subsection{Morar Nova-lorquino}

Do morar Nova-lorquino, aproximar as Comunas-Freud-Marx a habitação com o estilo desregrado popular, sem muitos predicados, porém simples, franco e integrado à paisagem. Dissolver a privacidade no prosseguimento espacial. Incorporar a importância do "barato, de graça é melhor" numa descontextualização "quase perversa". Aproximar público e privado num "jogo da desordem" como apego criativo do ambiente popular e festivo. Cogitar as sobras e transforma-las em ocorrências inventivas, gracejadas e extraordinárias. Usar e abusar da reciclagem. Conhecer a casa humilde liberal, com a apropriação pela instalação da coletividade. Partes da cidade transformadas pela tribo popular, a qual constrói para si novo limite civil e muda a identidade do local. Atribuir casa e oficina no mesmo lugar. Exemplos de loft nova-iorquino:

\section{EUA. Área: $278 \mathrm{~m}^{2}$. Ano do projeto: 2013 (Figuras 68 a 75) \\ Loft Tribeca. Arquitetos: Andrew Franz Architect. Localização: Nova York, NY,}

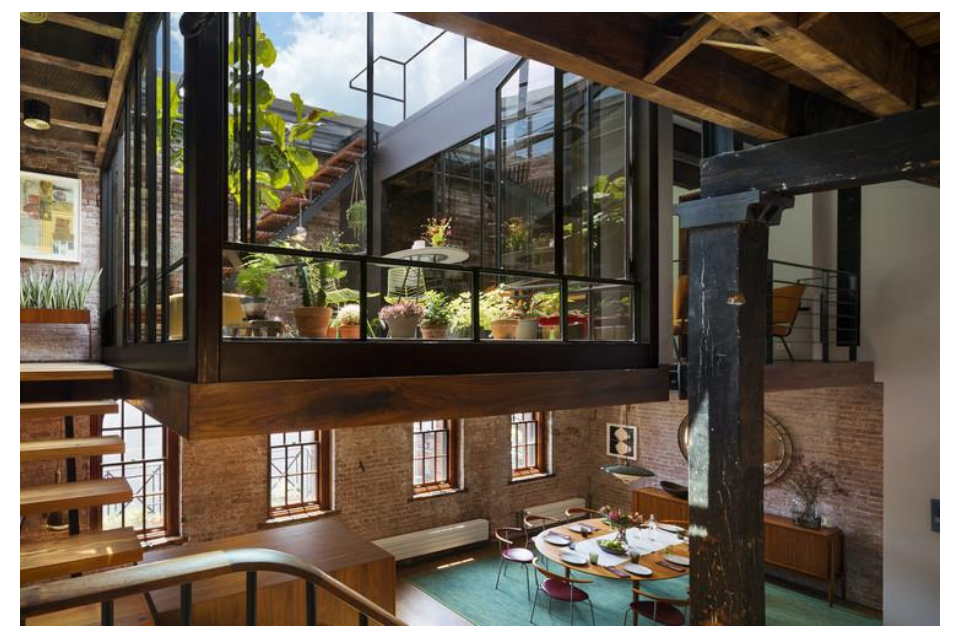

Figura 68. Perspectiva interna.

Fonte: https://bit.ly/2N6pWr3, acessado em 24/11/2017.

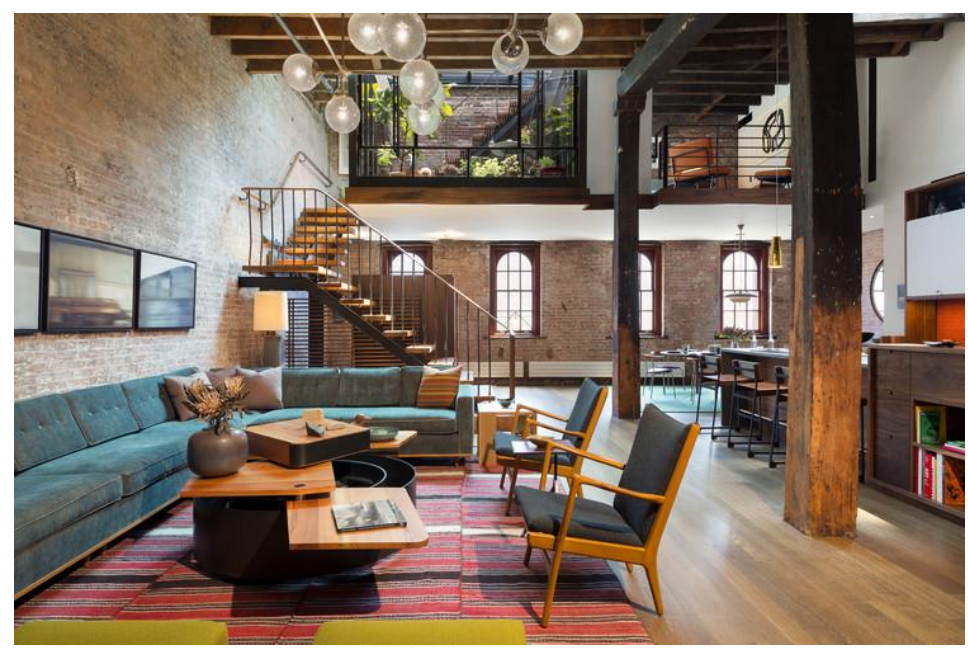

Figura 69. Perspectiva interna.

Fonte: https://bit.ly/2N6pWr3, acessado em 24/11/2017. 


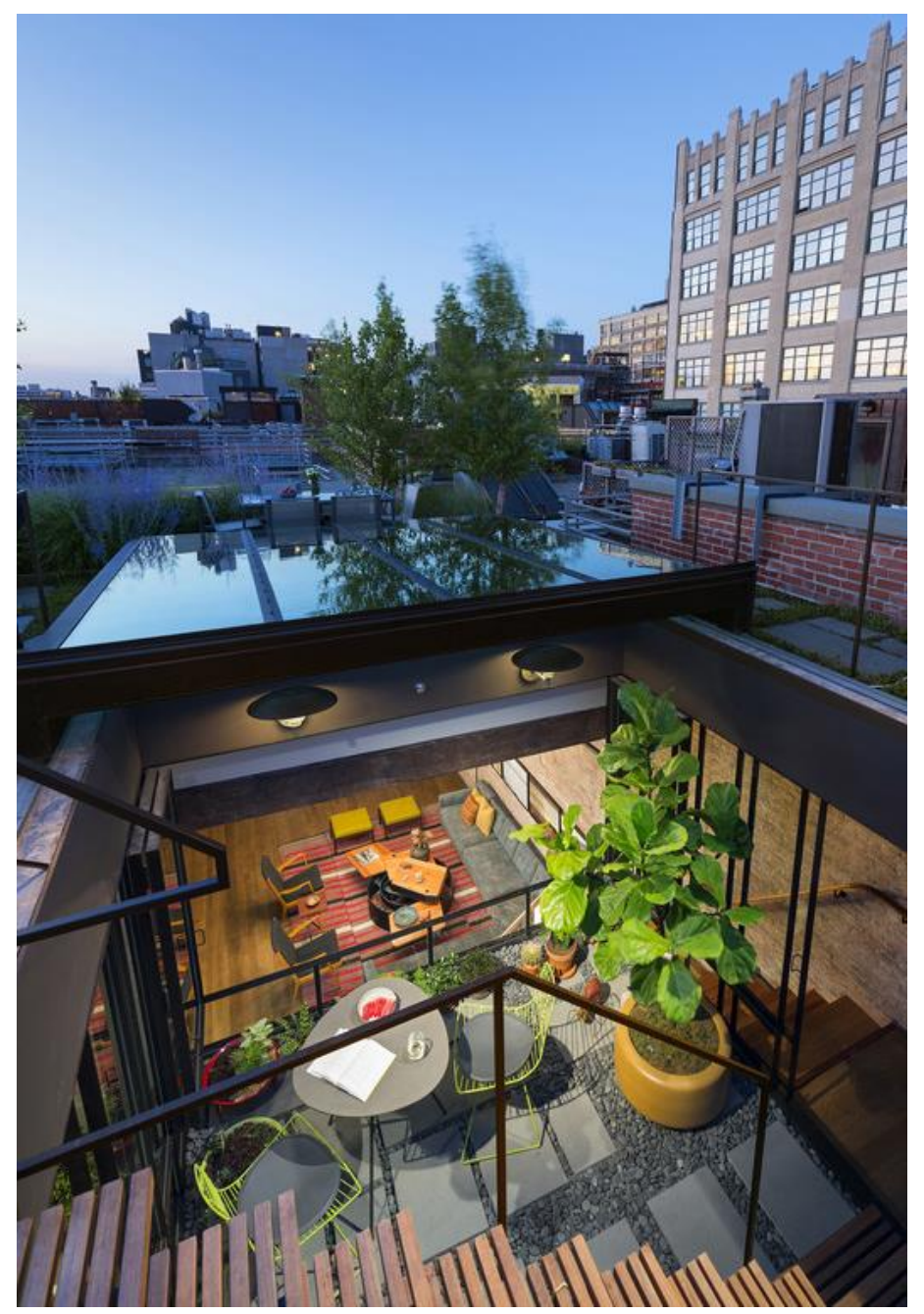

Figura 70. Perspectiva.

Fonte: https://bit.ly/2N6pWr3, acessado em 24/11/2017.

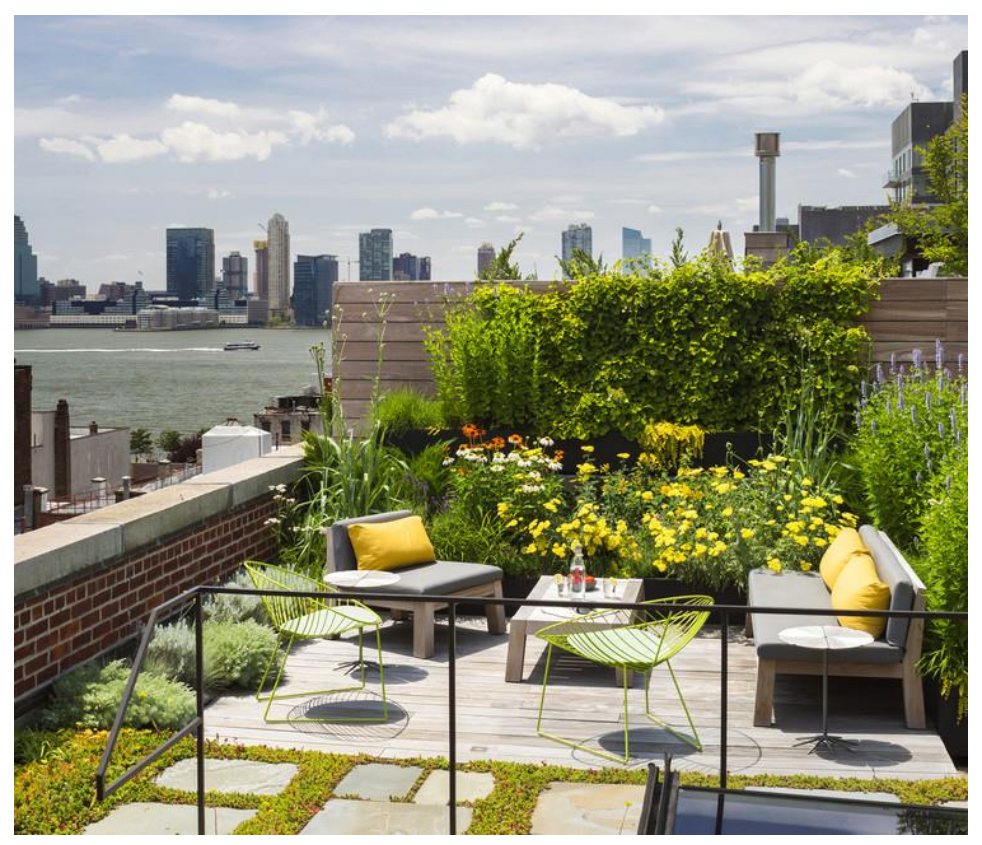

Figura 71. Terraço.

Fonte: https://bit.ly/2N6pWr3, acessado em 24/11/2017. 


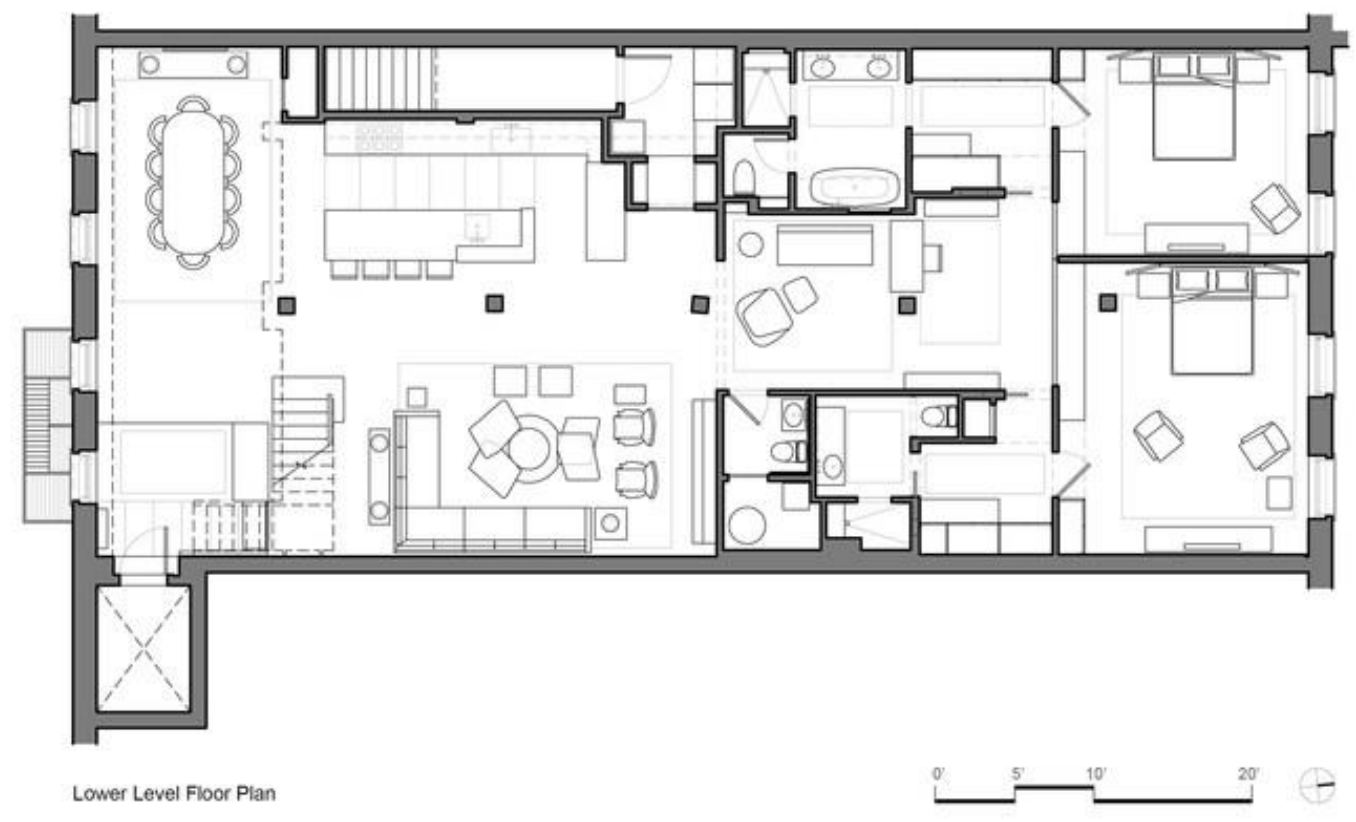

Figura 72. Planta baixa térreo.

Fonte: https://bit.ly/2N6pWr3, acessado em 24/11/2017.

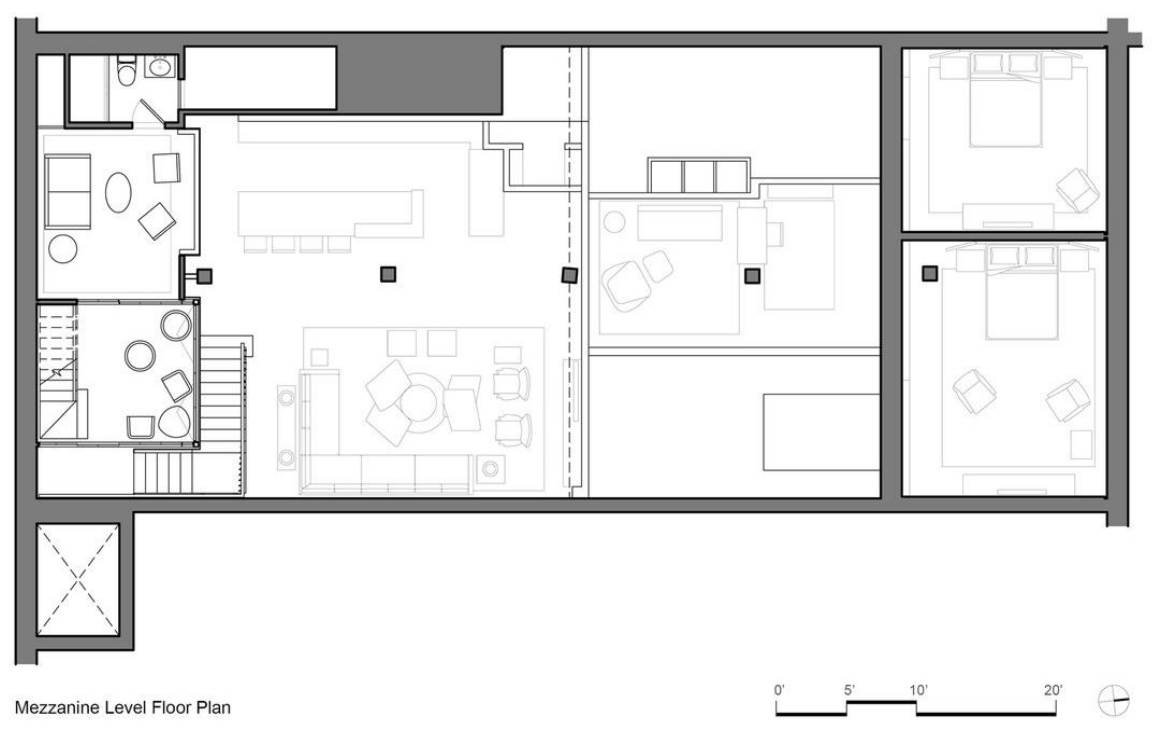

Figura 73. Planta baixa mezanino.

Fonte: https://bit.ly/2N6pWr3, acessado em 24/11/2017. 


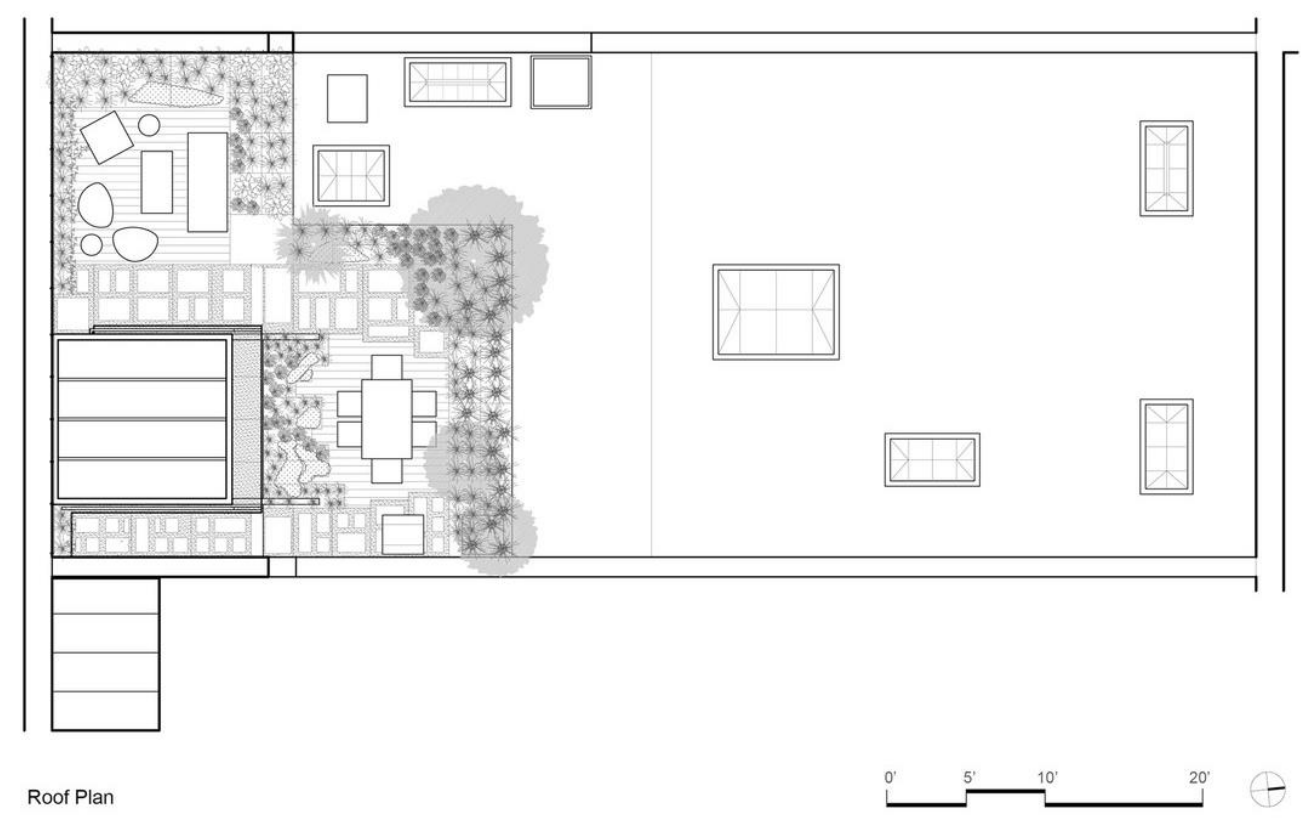

Figura 74. Planta baixa terraço.

Fonte: https://bit.ly/2N6pWr3, acessado em 24/11/2017.

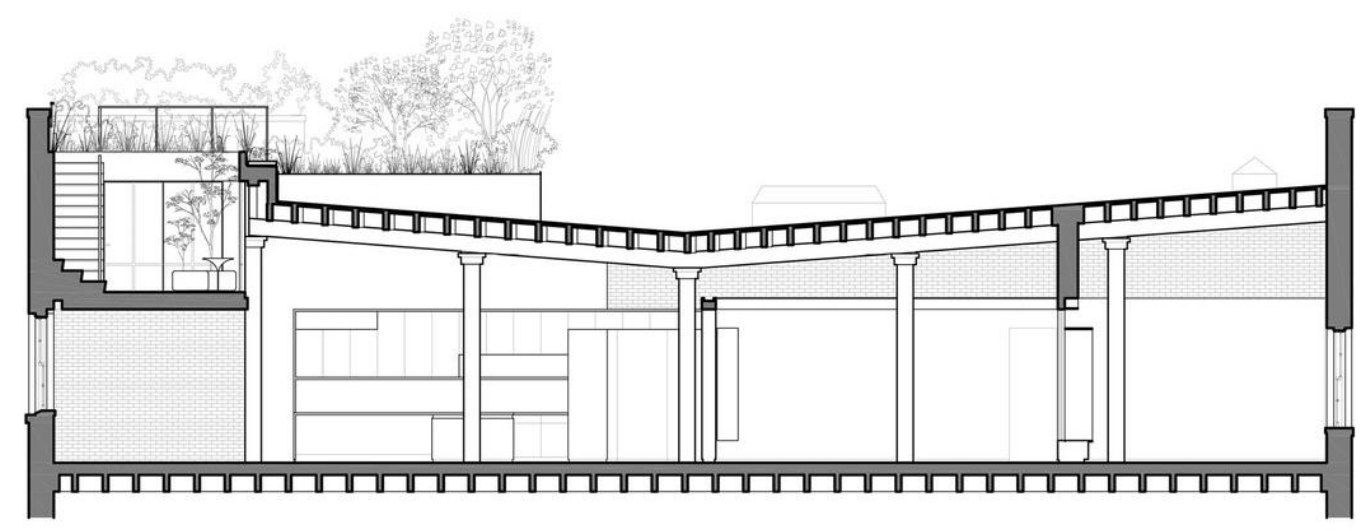

Section

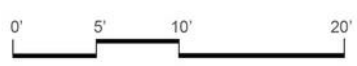

Figura 75. Corte.

Fonte: https://bit.ly/2N6pWr3, acessado em 24/11/2017. 
Grande Cabana DLPM. Arquitetos: Juan Carlos Bamba, Ignacio de Teresa, Alejandro González. Localização: Província de Manabí, Equador. Arquitetos Encarregadosos: Juan Carlos Bamba, Ignacio de Teresa, Alejandro González. Área: 411.0 m2. Ano do Projeto: 2016 (Figuras 76 a 80).

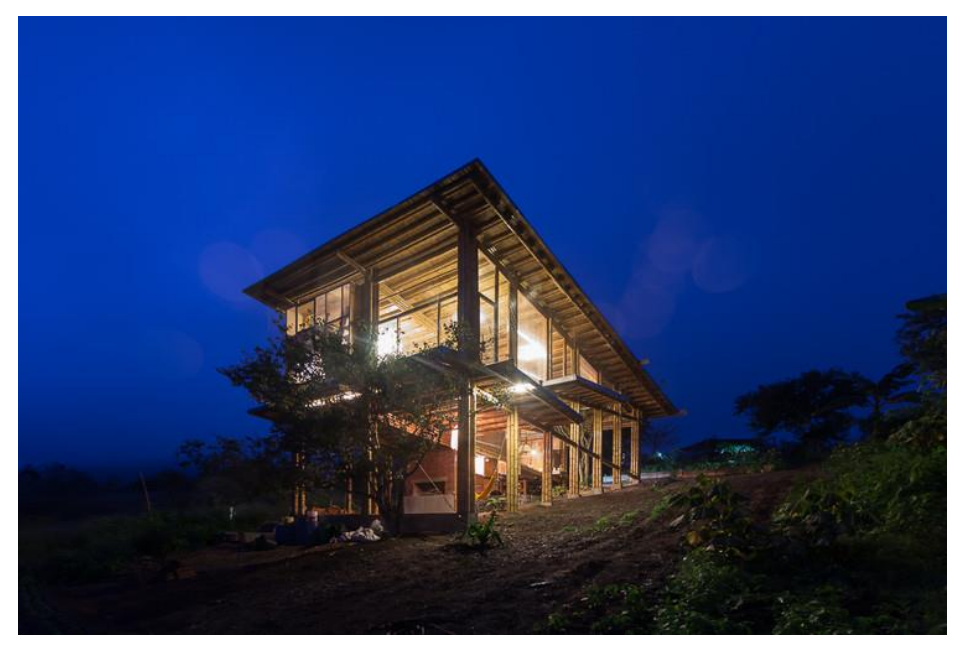

Figura 76. Perspectiva externa.

Fonte: https://bit.ly/2w1XmRj, acessado em 24/11/2017.

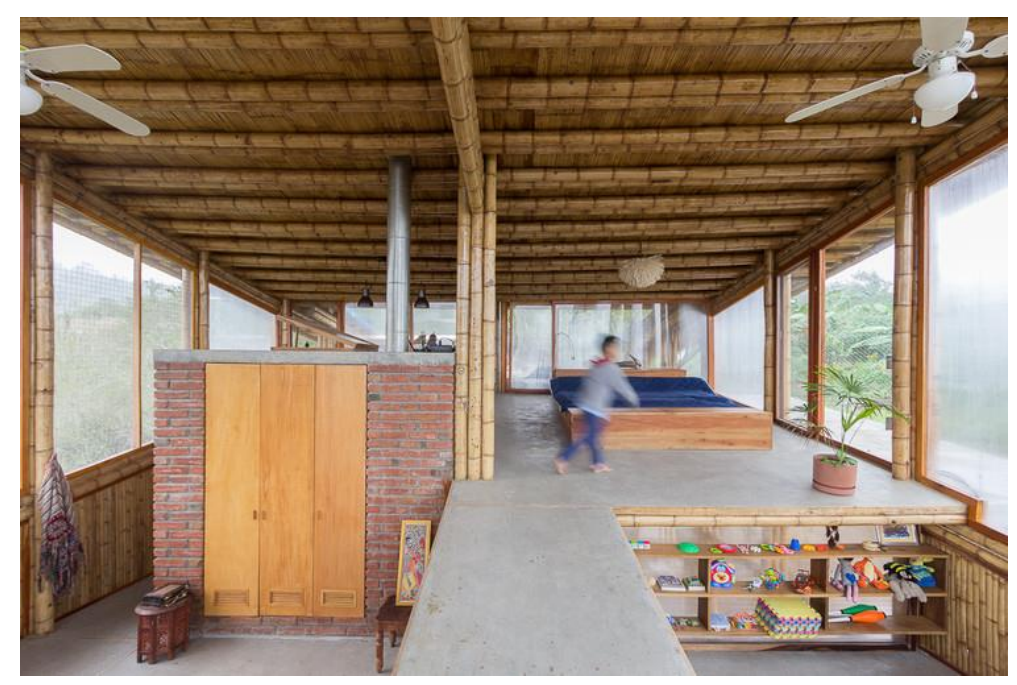

Figura 77. Perspectiva interna.

Fonte: https://bit.ly/2w1XmRj, acessado em 24/11/2017. 


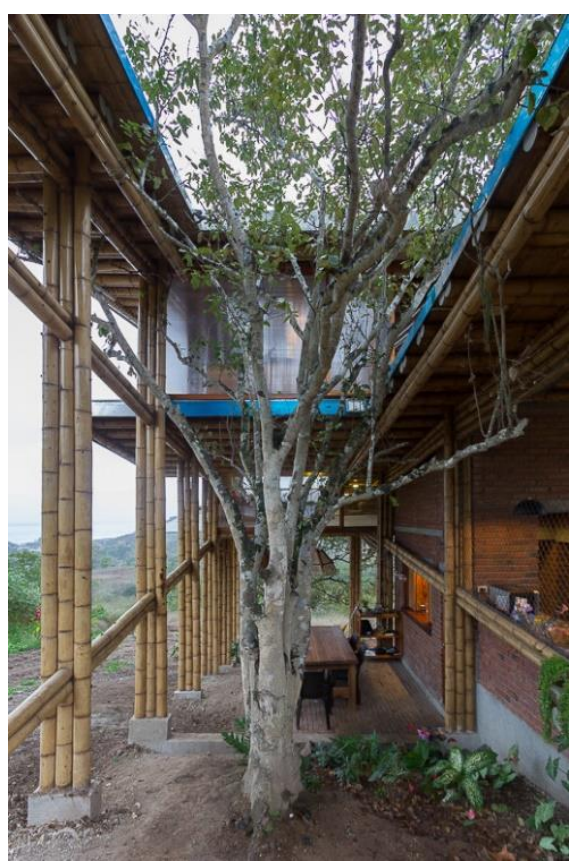

Figura 78. Perspectiva interna.

Fonte: https://bit.ly/2w1XmRj, acessado em 24/11/2017.

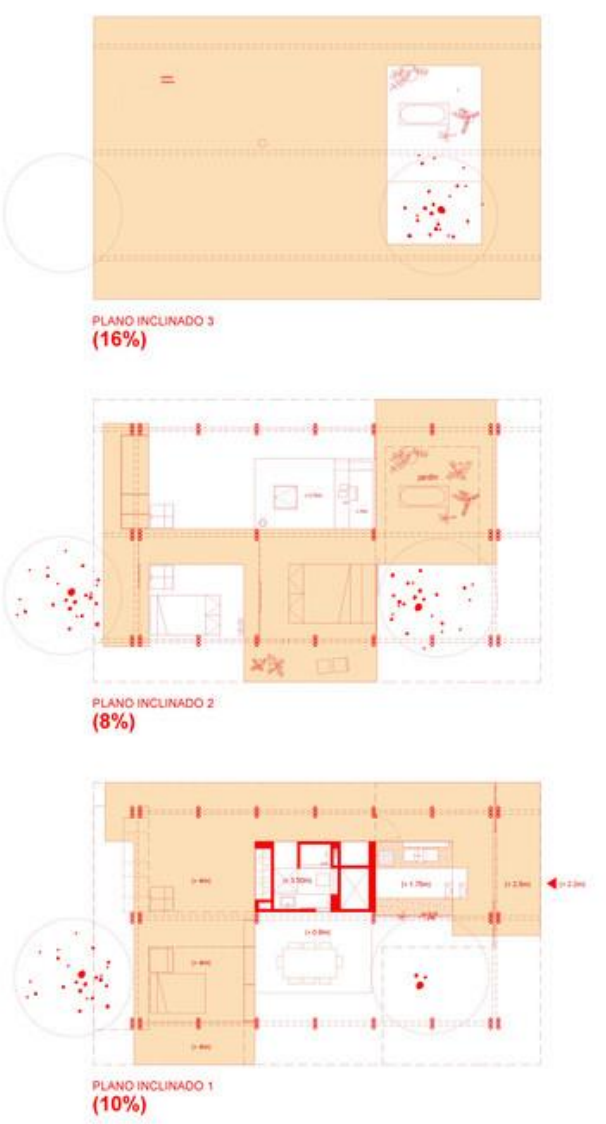

Figura 79. Plantas baixas.

Fonte: https://bit.ly/2w1XmRj, acessado em 24/11/2017. 


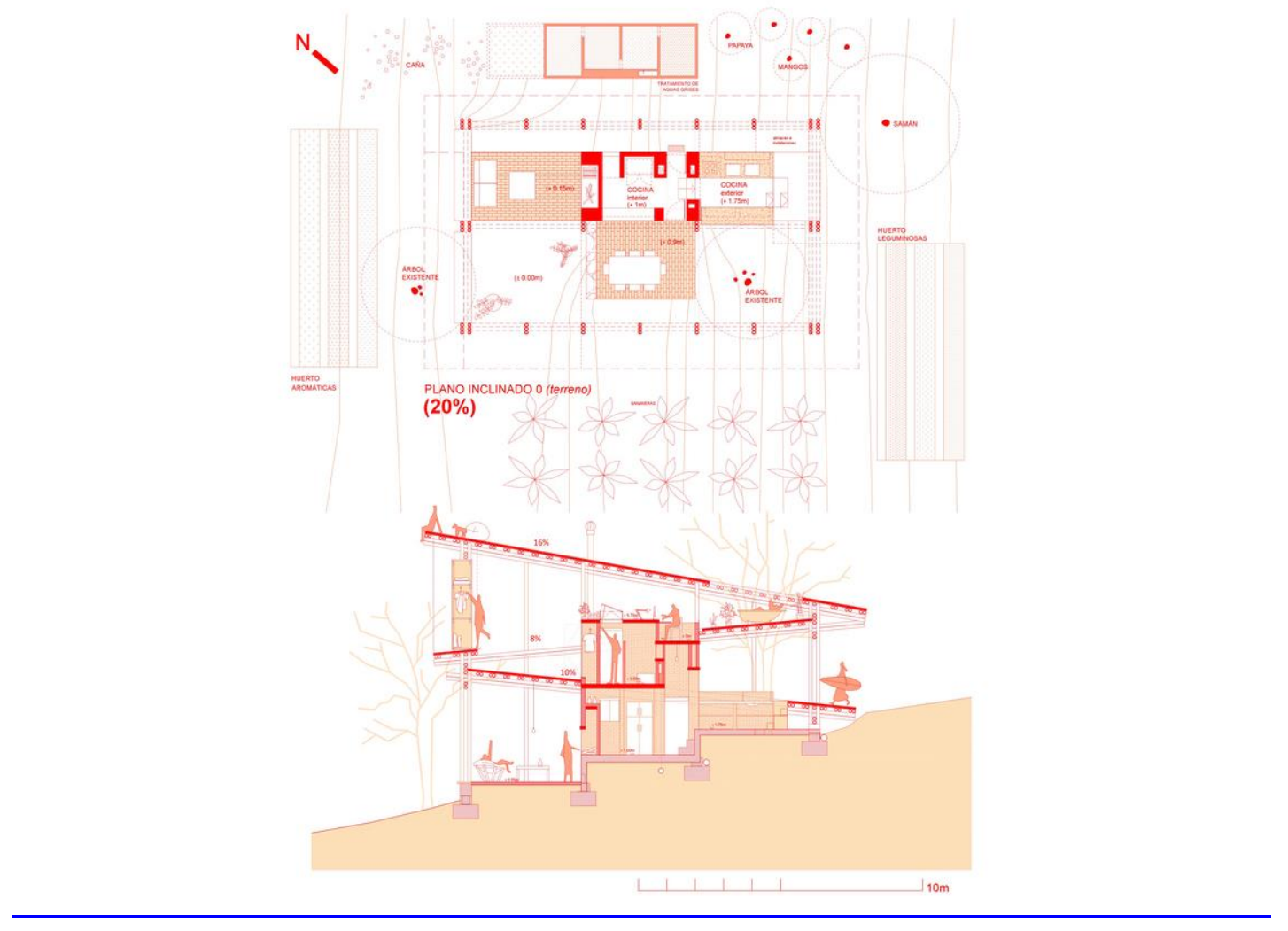

Figura 80. Planta baixa e corte.

Fonte: https://bit.ly/2w1XmRj, acessado em 24/11/2017.

Estúdio dos Arquitetos. Arquitetos: Eduardo Medeiros Arquitetura e Design, Bela Cruz Arquitetura, Studio Migliori. Localização: Goiânia, Goiás, Brasil: Área: 53.0 m2. Ano do projeto: 2016 (Figuras 81, 82 e 83).

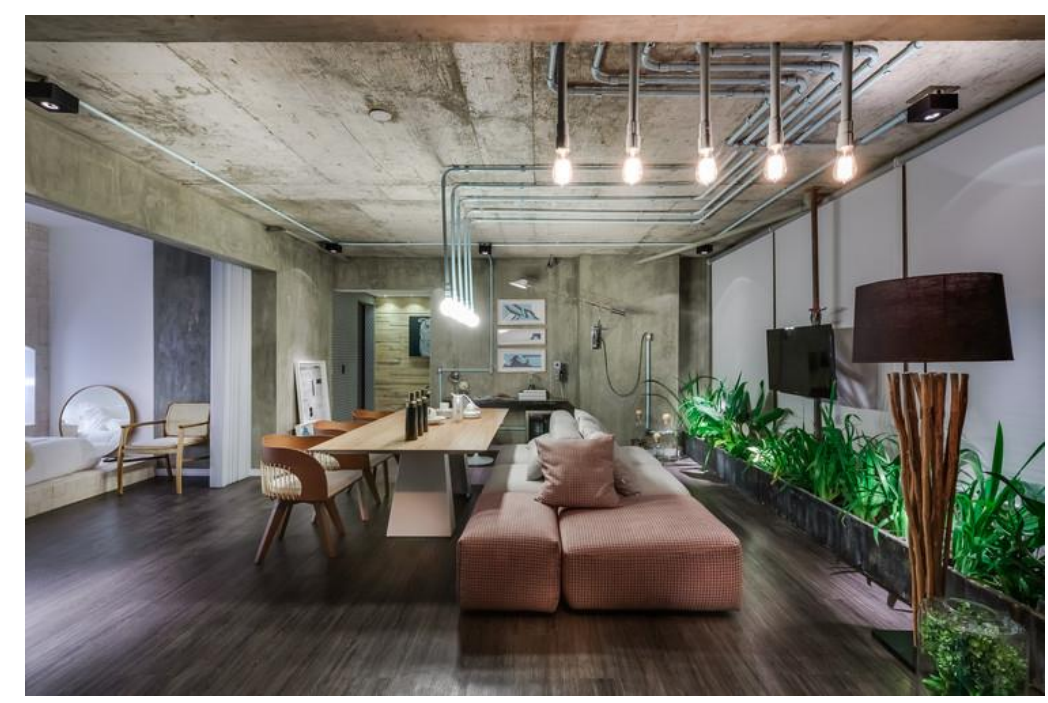

Figura 81. Perspectiva interna.

Fonte: https://bit.ly/2wc4gCG, acessado em 24/11/2017. 


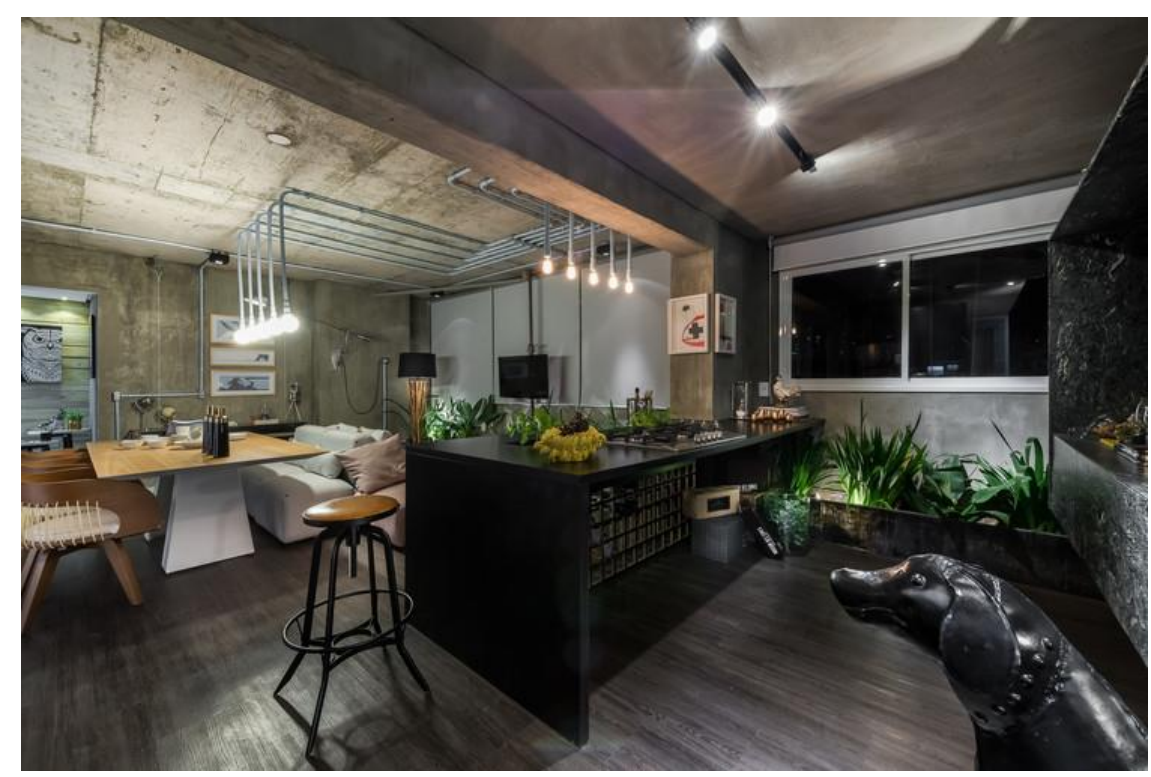

Figura 82. Perspectiva interna.

Fonte: https://bit.ly/2wc4gCG, acessado em 24/11/2017.

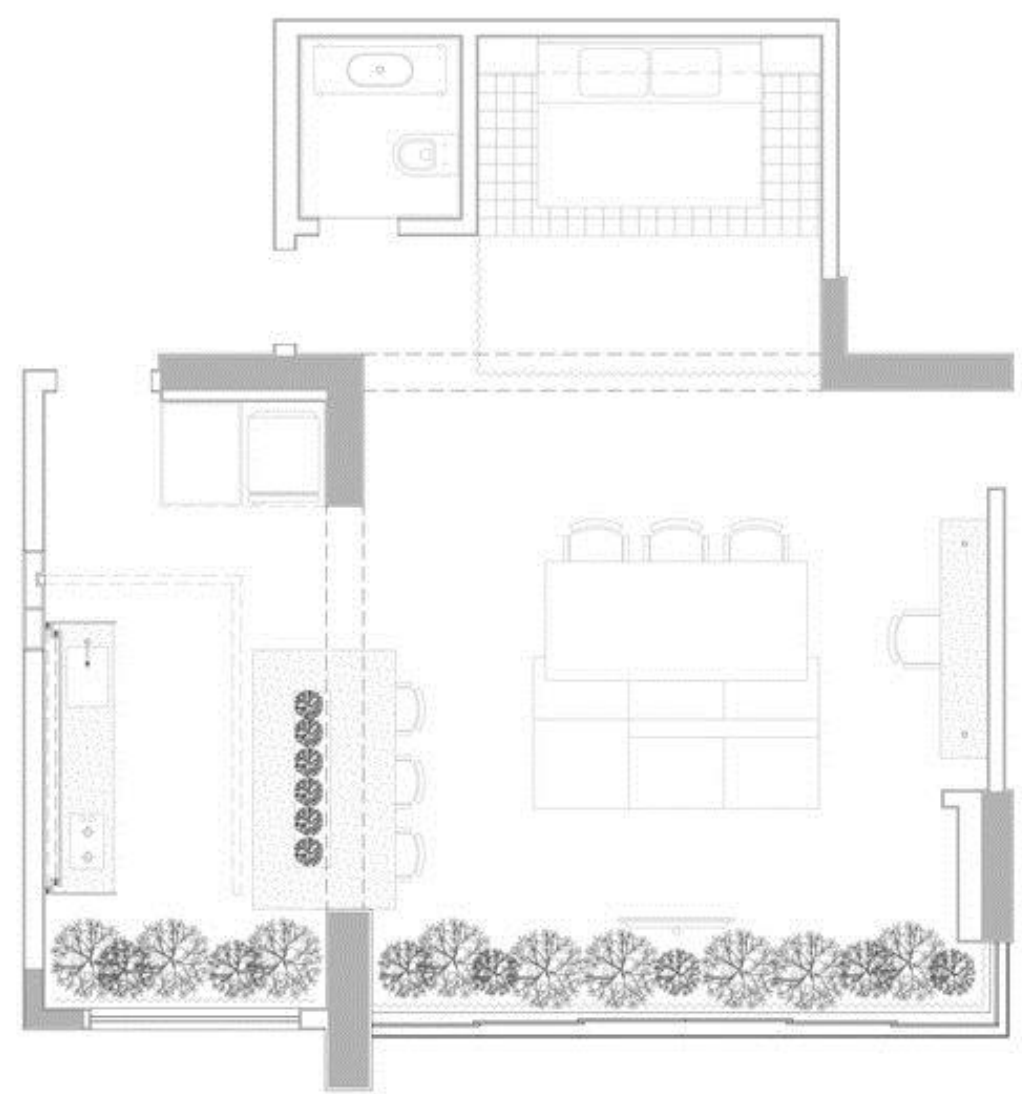

Figura 83. Planta baixa

Fonte: https://bit.ly/2wc4gCG, acessado em 24/11/2017. 
Loft. Arquitetos: Estúdio Cláudio Resmini. Localização: Moinhos de Vento, Porto Alegre - RS, Brasil. Colaboradores. Arq. Francine Azevedo e Arq. Alex Souza. Área: 68.0 m2. Ano do projeto: 2014 (Figuras 84 a 88).

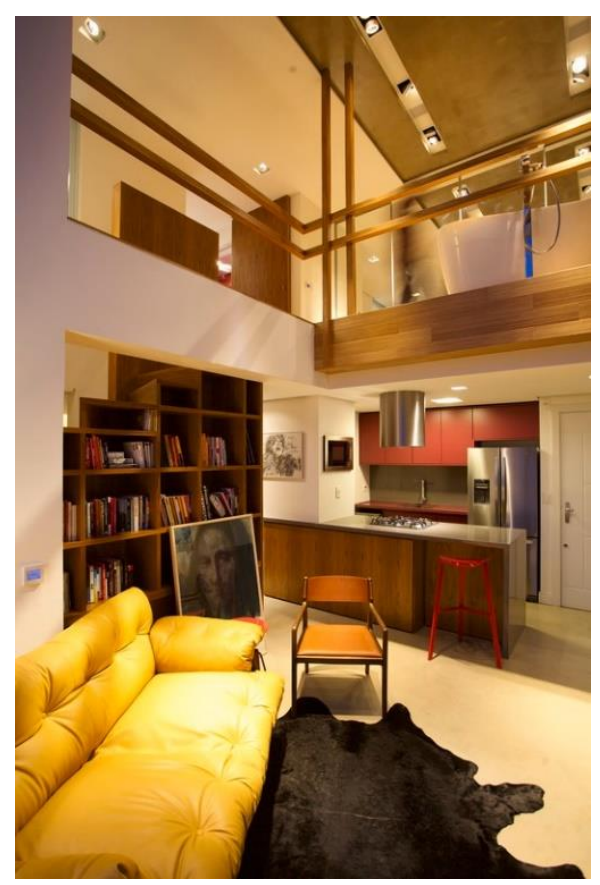

Figura 84. Perspectiva interna.

Fonte: https://bit.ly/2Mohpn8, acessado em 24/11/2017.

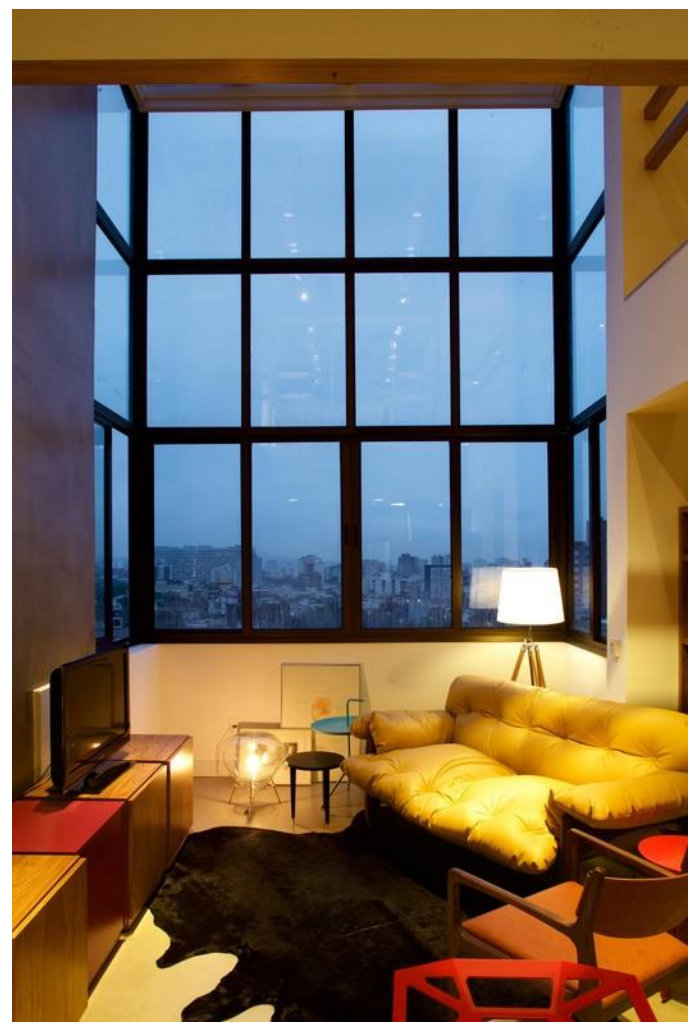

Figura 85. Perspectiva interna.

Fonte: https://bit.ly/2Mohpn8, acessado em 24/11/2017. 

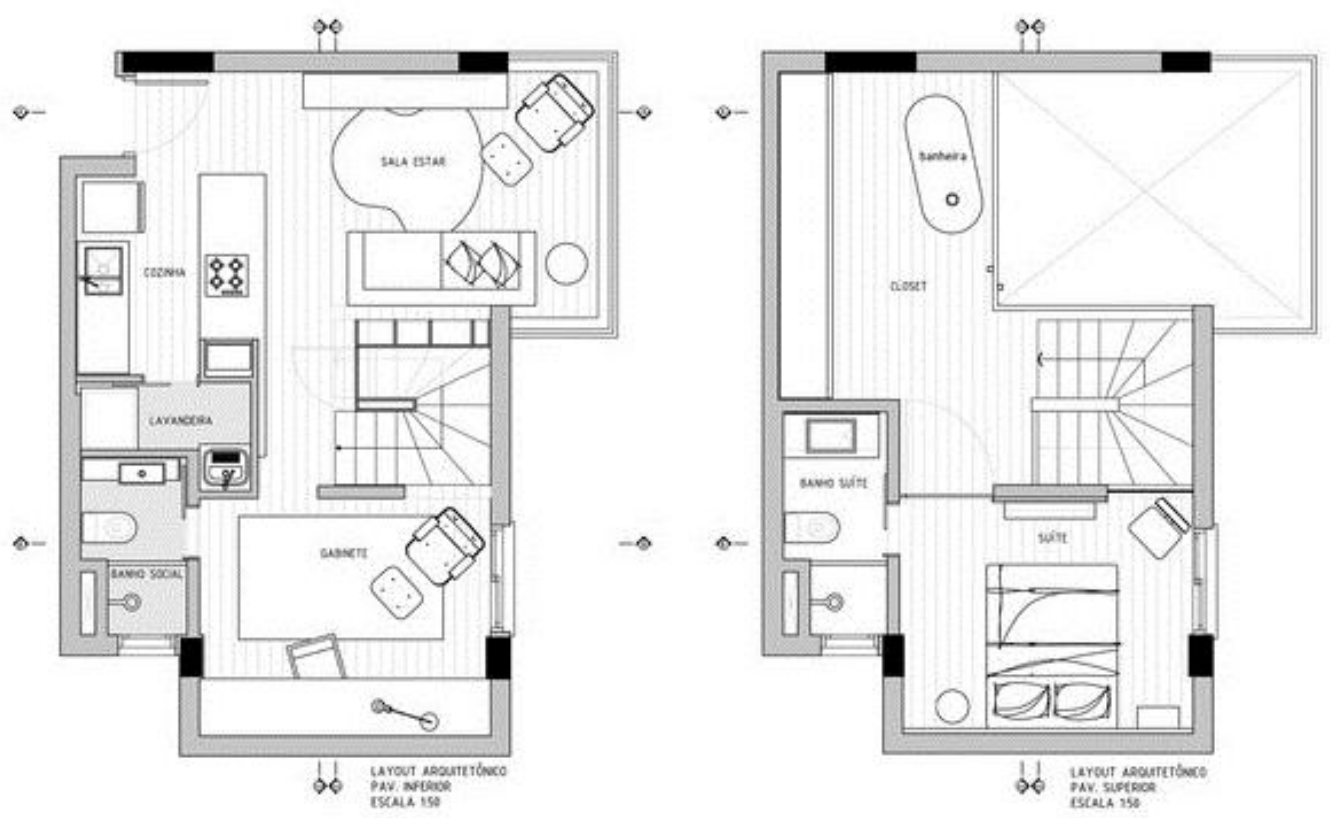

Figura 86. Plantas baixas - térreo e pav. Superior..

Fonte: https://bit.ly/2Mohpn8, acessado em 24/11/2017.
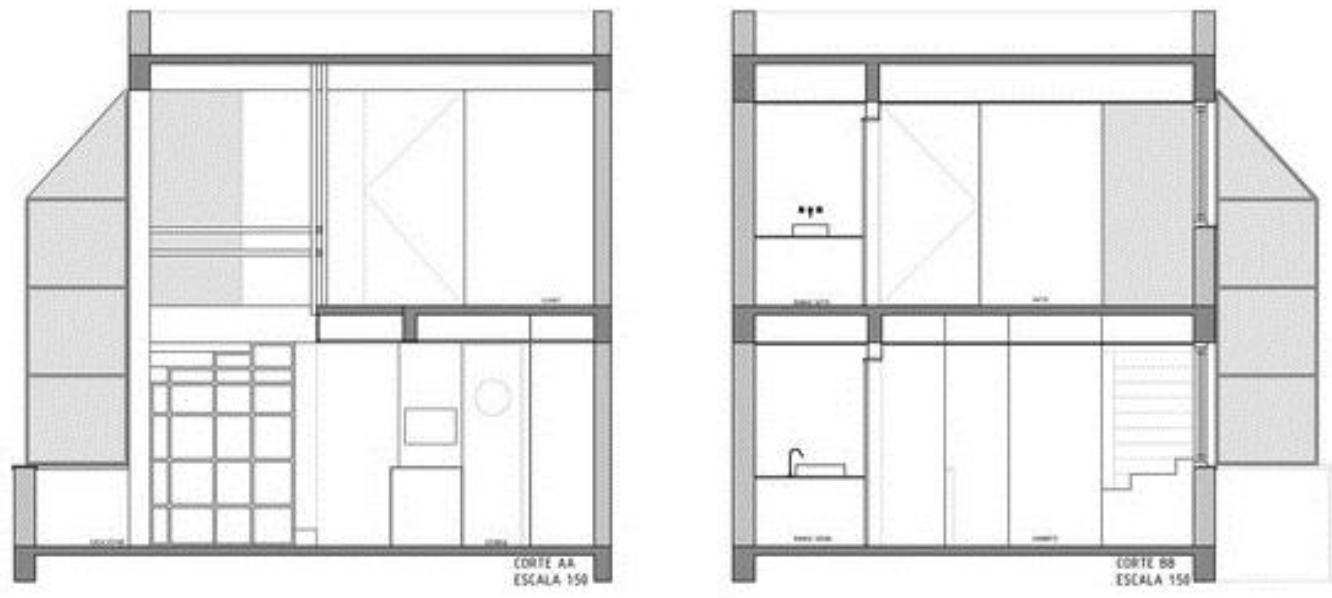

Figura 87. Cortes.

Fonte: https://bit.ly/2Mohpn8, acessado em 24/11/2017.
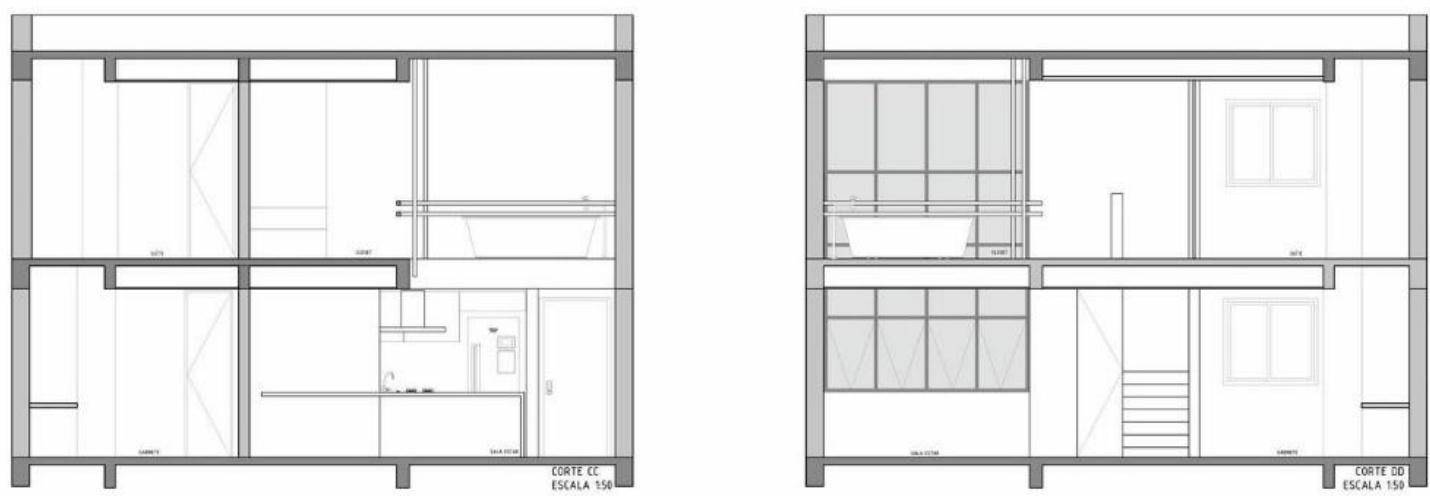

Figura 88. Cortes.

Fonte: https://bit.ly/2Mohpn8, acessado em 24/11/2017. 


\subsection{Casa fenomenológica}

Da habitação fenomenológica, apropriar-se da imaginação, única com a habilidade de superar até mesmo à miséria. Cultuar a "relação humilde" e os costumes que dela provê. Investigar os conhecimentos essenciais, as divagações do pensamento e do sentido popular. Compreender a heterogeneidade do espaço sensorial do povo, com sua rede de estímulos e intencionalidades. Valorizar a casa, a rua e o bairro para que o habitante tenha orgulho de onde mora. Reconstituir o estilhaço cenográfico e intricado no bazar humilde. Valorizar o "eu popular" no mundo, que se alimenta mutualmente com seus fenômenos físicos, sua própria subjetividade, sensação e intelecto. A cidade popular como uma soma densa de peças que só o tempo destilará. Exemplos de Casas Fenomenológicas:

Casa Fenomenológica. Arquitetos: Estudio Botteri-Connell. Localização: City Bell, Argentina. Arquiteto Encarregado: Arqs. Sofía Botteri Cappa, Patricio Gabriel Connell. Colaboradores: Rosalía Vicente, José Chaves. Área: 320,0 m². Ano do projeto: 2012 (Figuras 89 a 98)

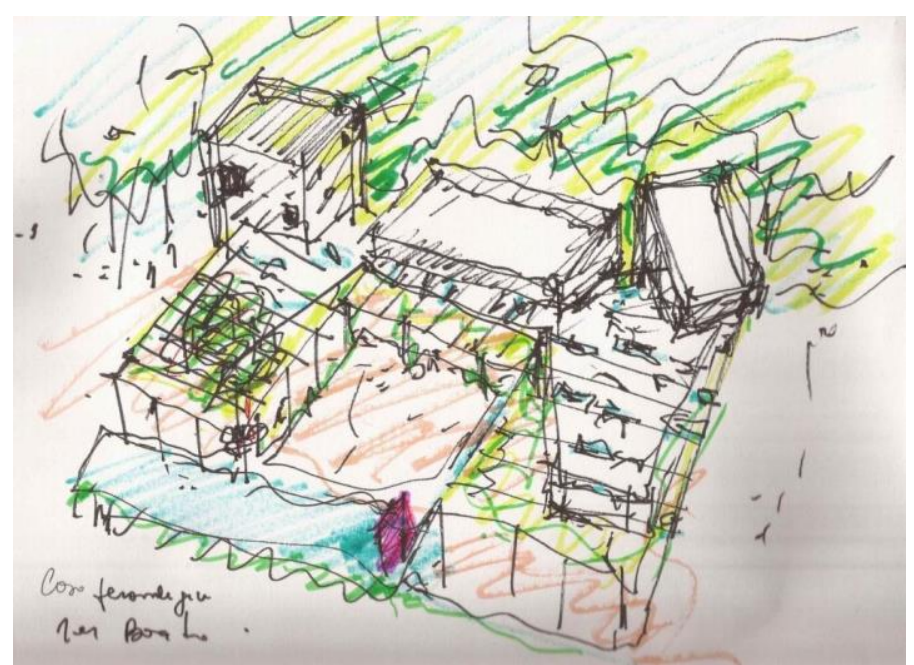

Figura 89. Croqui da volumetria Fonte: https://bit.ly/2Mou1uq, acessado em 17/10/2017.

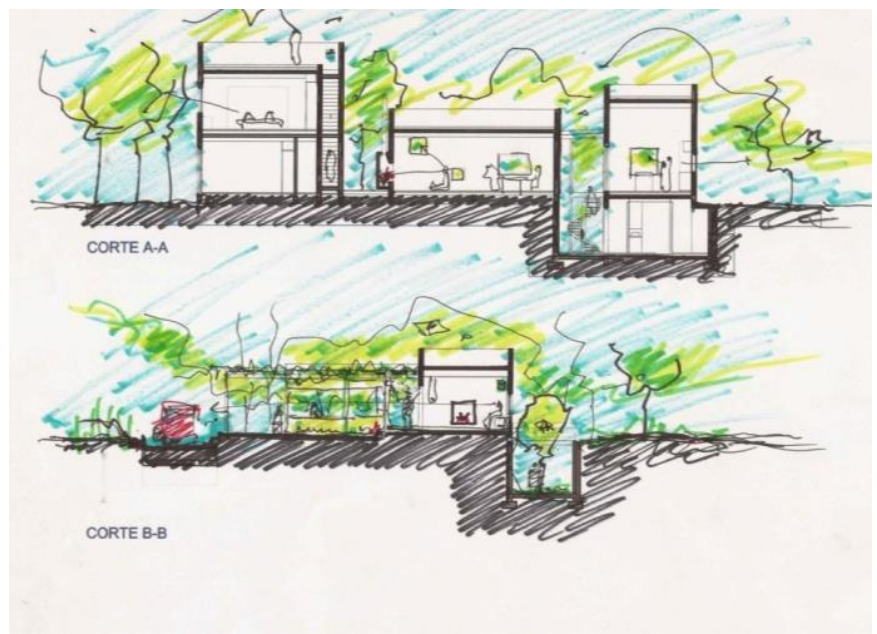

Figura 90. Corte esquemático.

Fonte: https://bit.ly/2Mou1uq, acessado em 17/10/2017. 


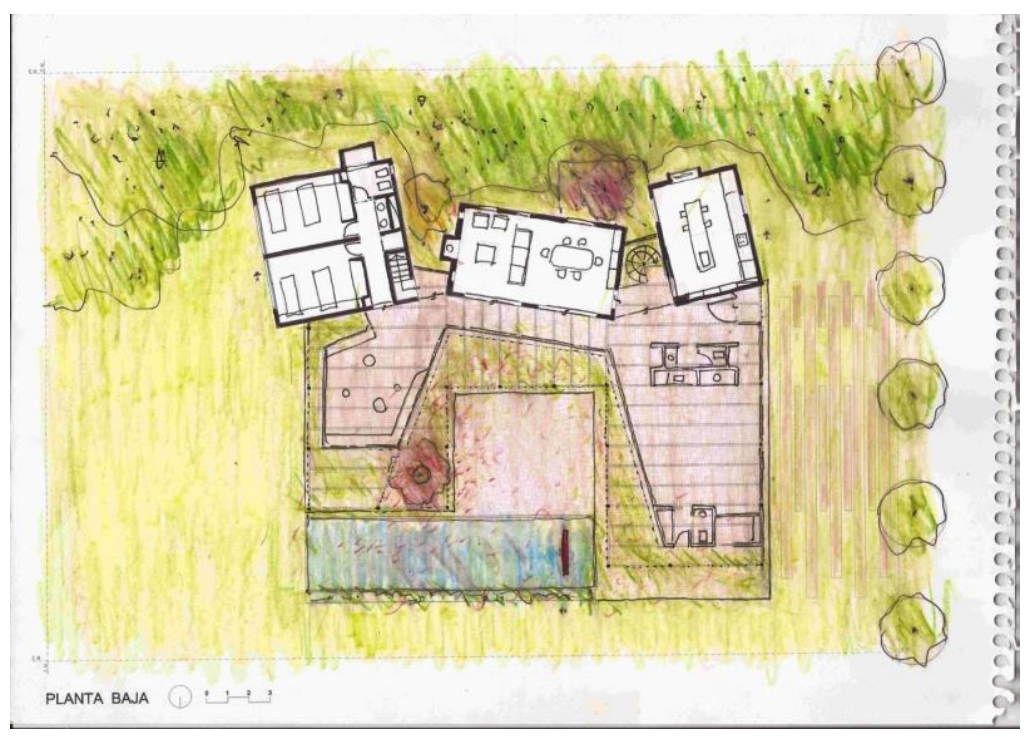

Figura 91. Planta baixa.

Fonte: https://bit.ly/2Mou1uq, acessado em 17/10/2017.

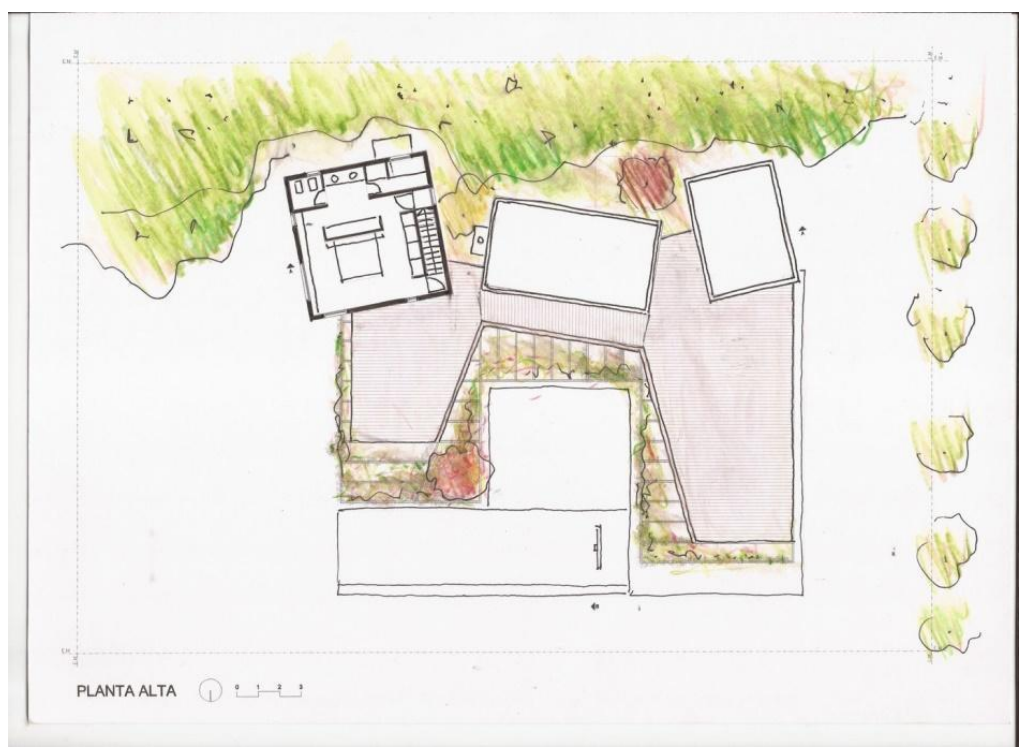

Figura 92. Planta baixa.

Fonte: https://bit.ly/2Mou1uq, acessado em 17/10/2017.

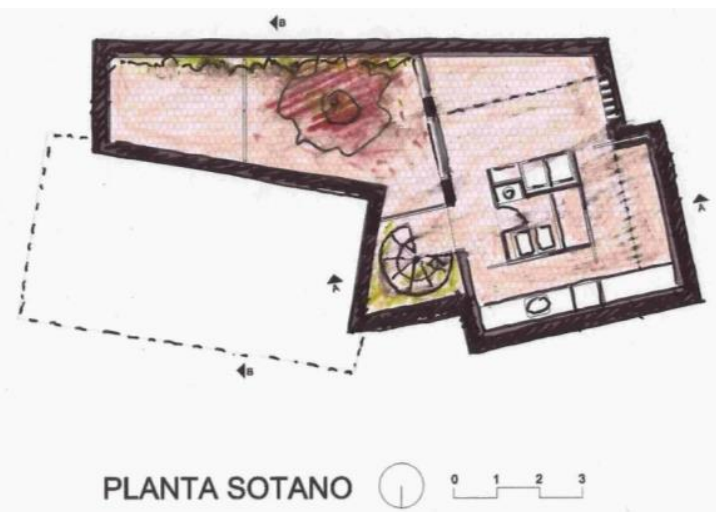

Figura 93. Planta baixa sótão.

Fonte: https://bit.ly/2Mou1uq, acessado em 17/10/2017. 


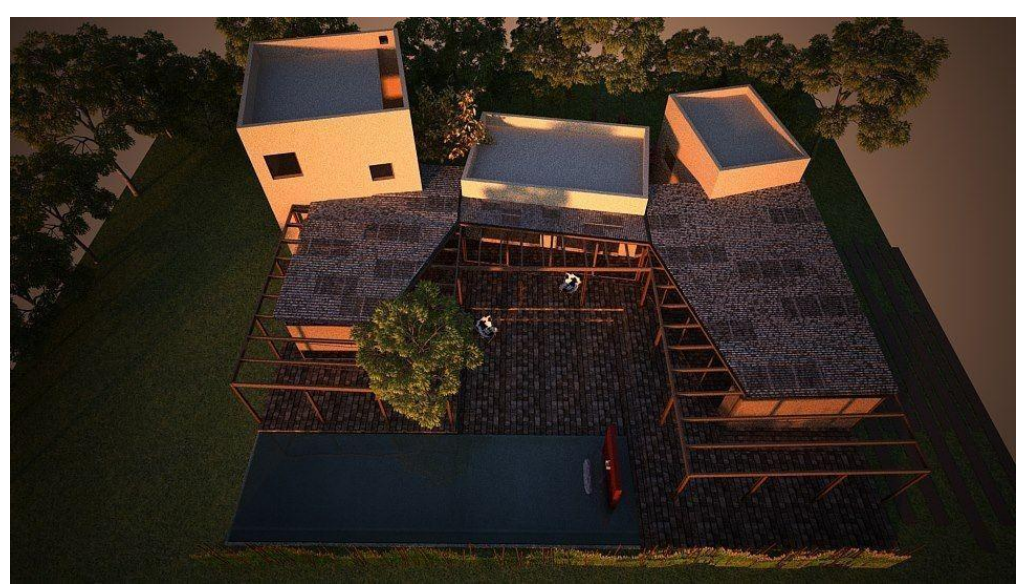

Figura 94. 3D.

Fonte: https://bit.ly/2Mou1uq, acessado em 17/10/2017.

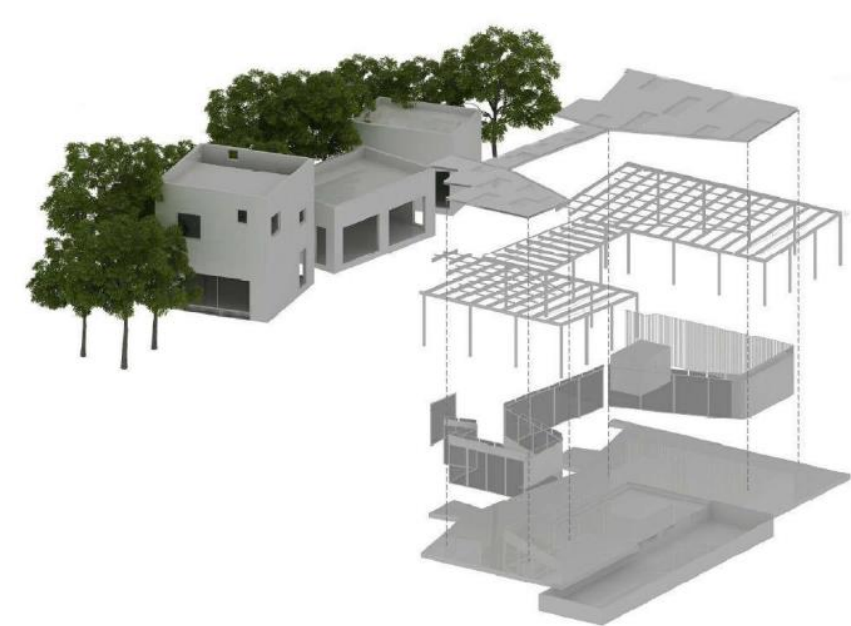

Figura 95. Esquema estrutural.

Fonte: https://bit.ly/2Mou1uq, acessado em 17/10/2017.

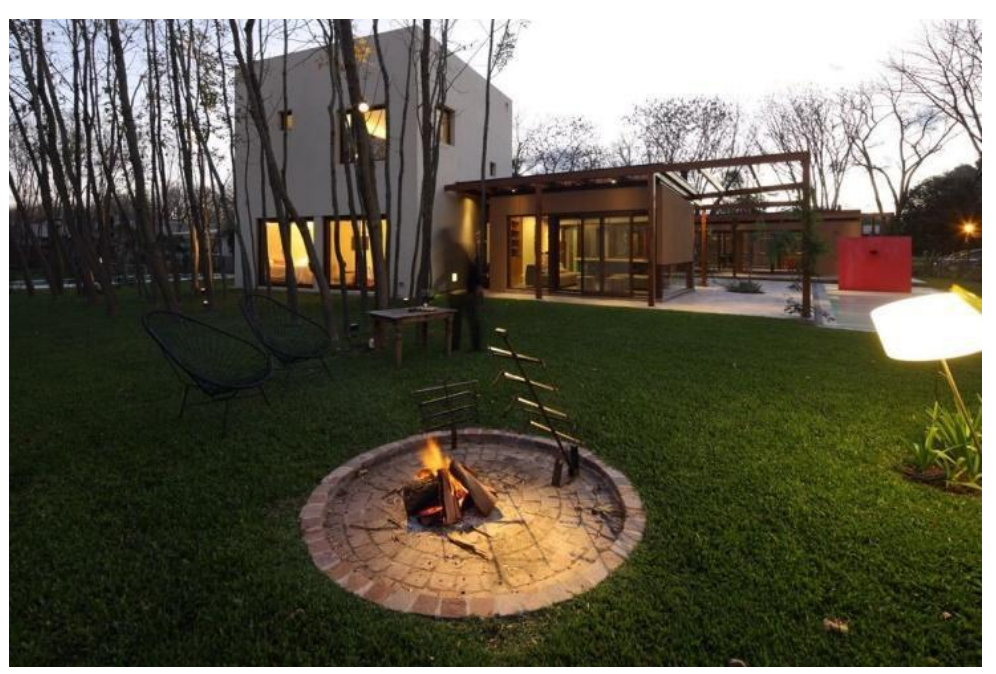

Figura 96. Perspectiva externa.

Fonte: https://bit.ly/2Mou1uq, acessado em 17/10/2017. 


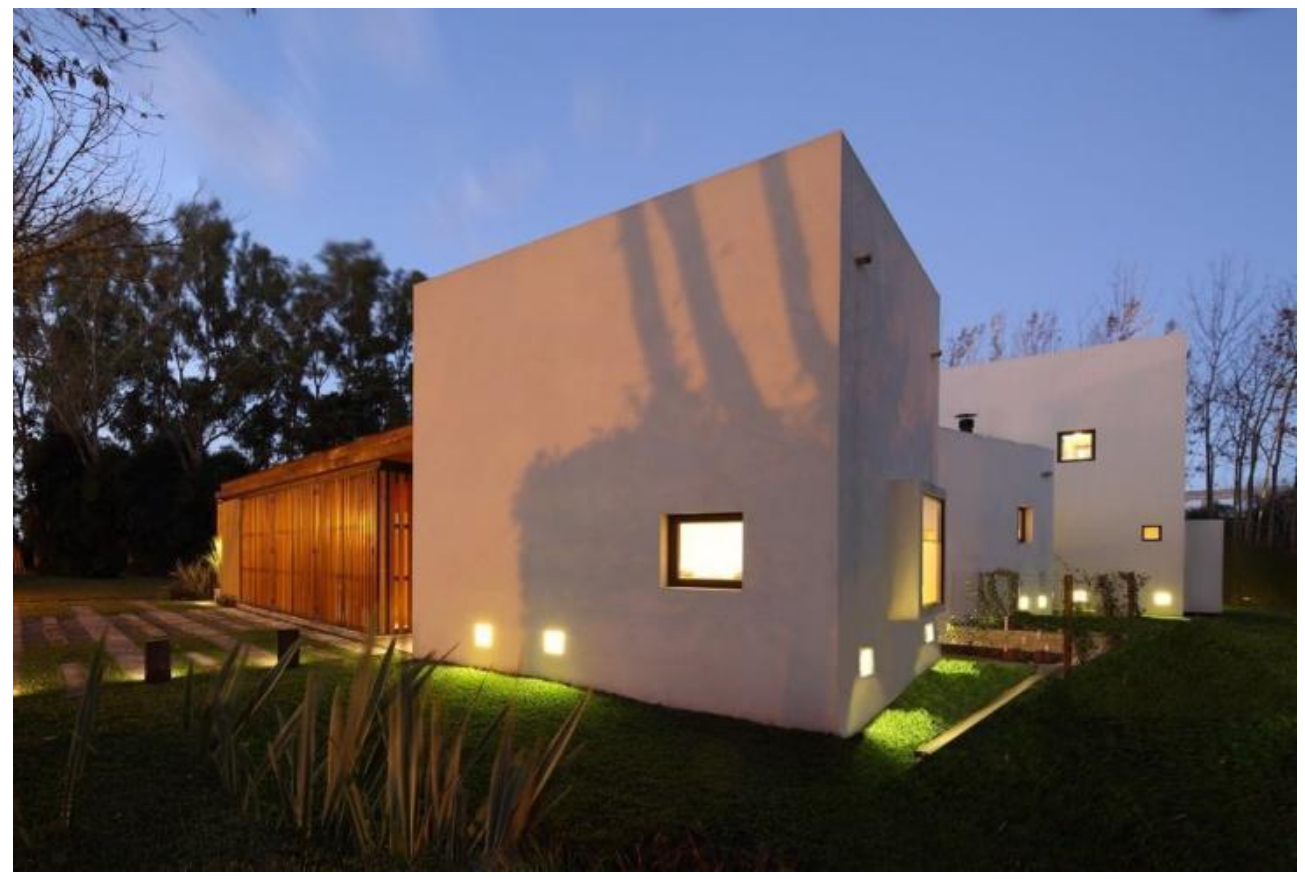

Figura 97. Perspectiva externa.

Fonte: https://bit.ly/2Mou1uq, acessado em 17/10/2017.

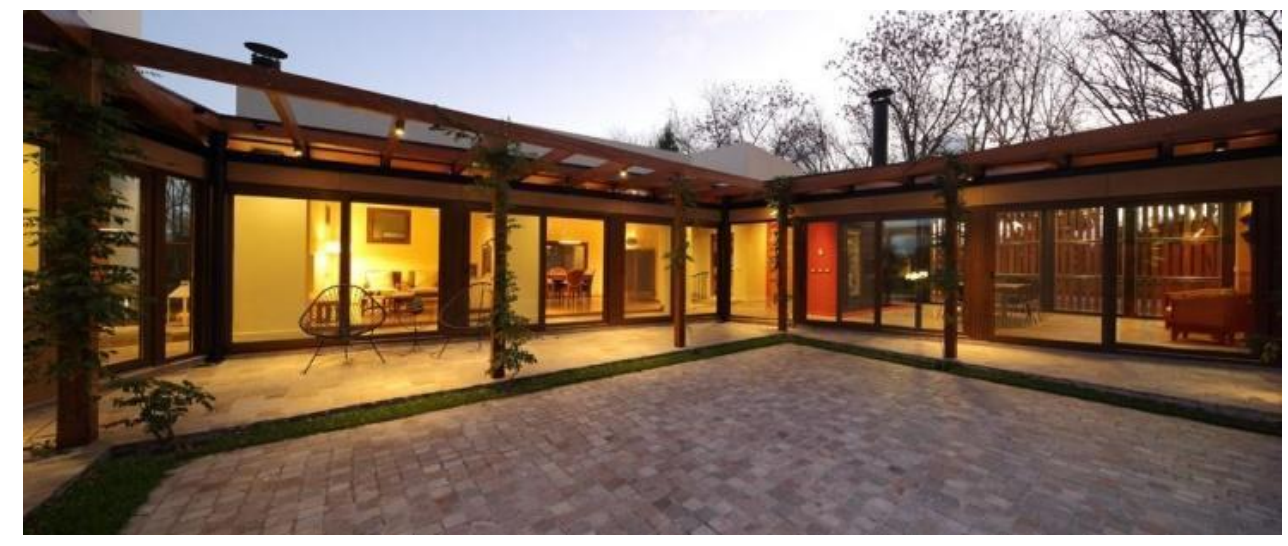

Figura 98. Perspectiva interna.

Fonte: https://bit.ly/2Mou1uq, acessado em 17/10/2017.

\subsection{Casa positivista}

Da casa positivista, arrebatar a mecânica produtiva. A execução do morar popular arranjada por decomposição de peças novamente ordenadas numa engrenagem mecânica. 
Utilizar o aparelho construtivo combinado por múltiplas camadas. Valorizar a tecnologia advinda de uma linha de produção. Atuar com economia, reduzir a proporção à menor quantidade possível sem comprometer a qualidade espacial. Resgatar a máquina de morar e sua retroalimentação. Aceitar a coletividade presente nos conjunto habitacional e seu otimismo social. Criar espaços públicos configurados pela própria habitação popular. Exemplos de casas positivistas:

Maison Mentana. Arquitetos: em architecture. Localização: Montreal, Canadá. Colaborador: Point Carré Entrepreneur général. Área: $290 \mathrm{~m}^{2}$. Ano do projeto: 2015 (Figuras 99 a 102).

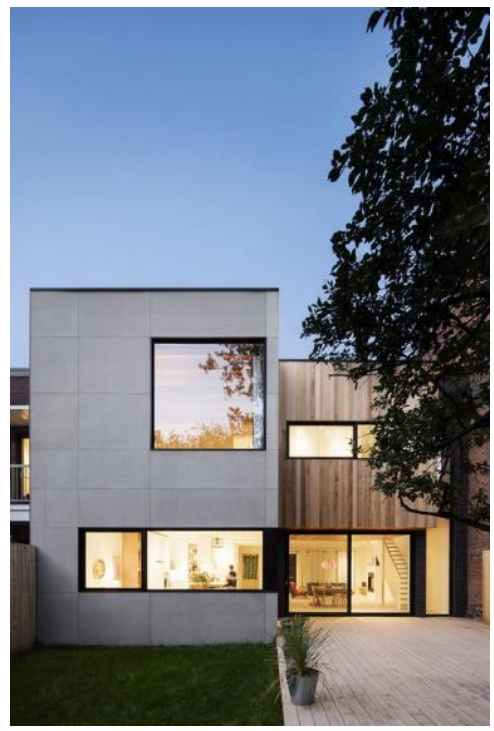

Figura 99. Perspectiva frontal. Fonte: https://bit.ly/2OVoLLt, acessado em 10/10/2017.

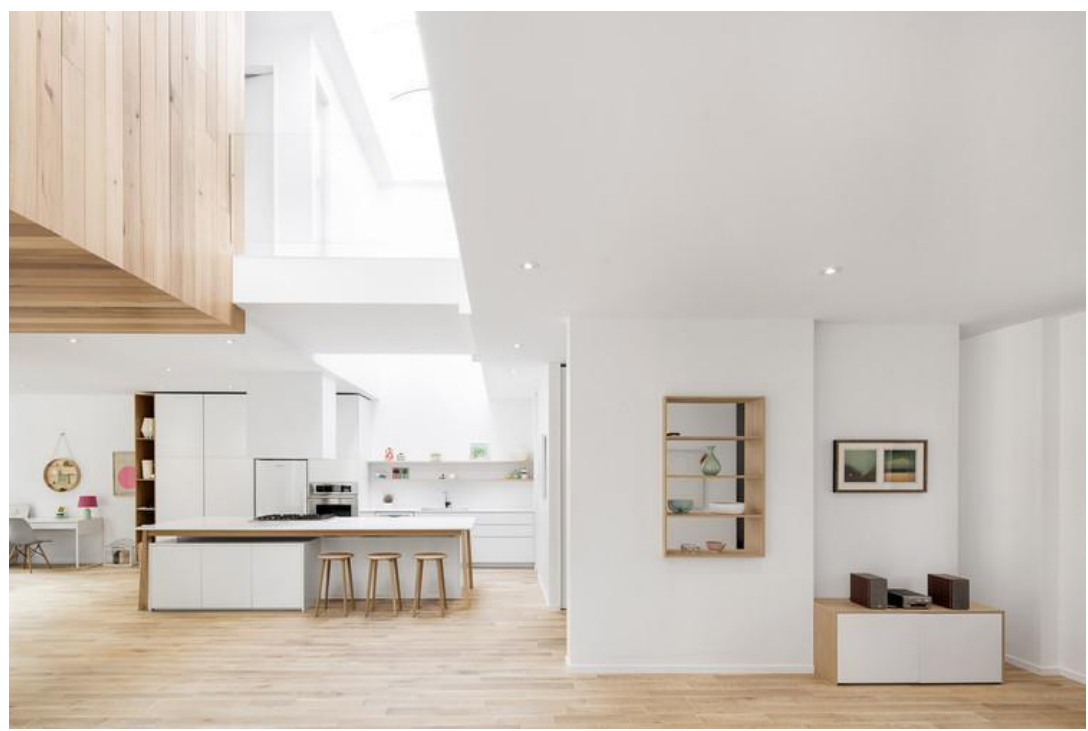

Figura 100. Perspectiva interna. Fonte: https://bit.ly/2OVoLLt, acessado em 10/10/2017. 


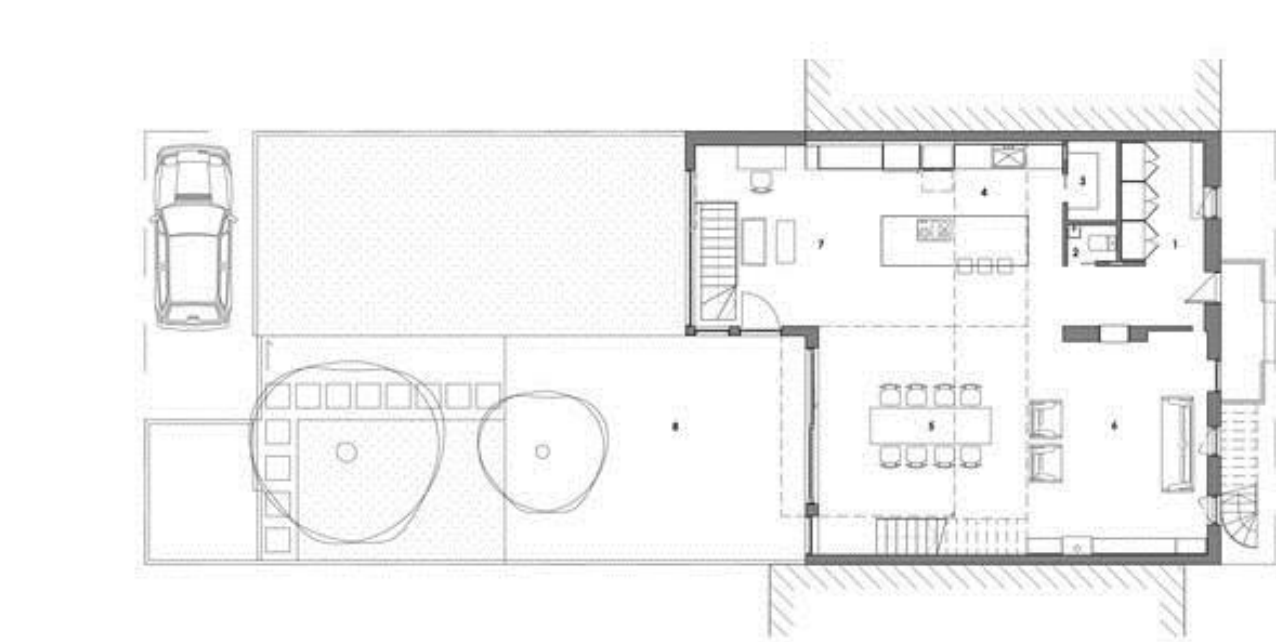

Figura 101. Planta baixa térreo.

Fonte: https://bit.ly/2OVoLLt, acessado em 10/10/2017.

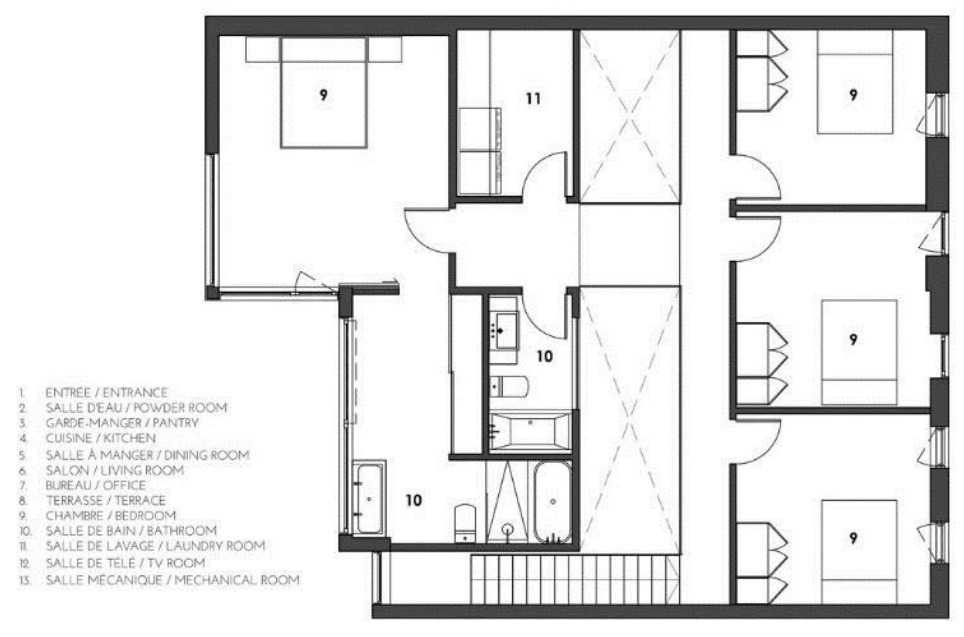

PLAN DE LEETAGE / SECOND FLOOR PLAN

Figura 102. Planta baixa do pav. Superior. Fonte: https://bit.ly/2OVoLLt, acessado em 10/10/2017. 

construída: 102 m². Localização: Okinawa, Japão (Figuras 103 a 106).

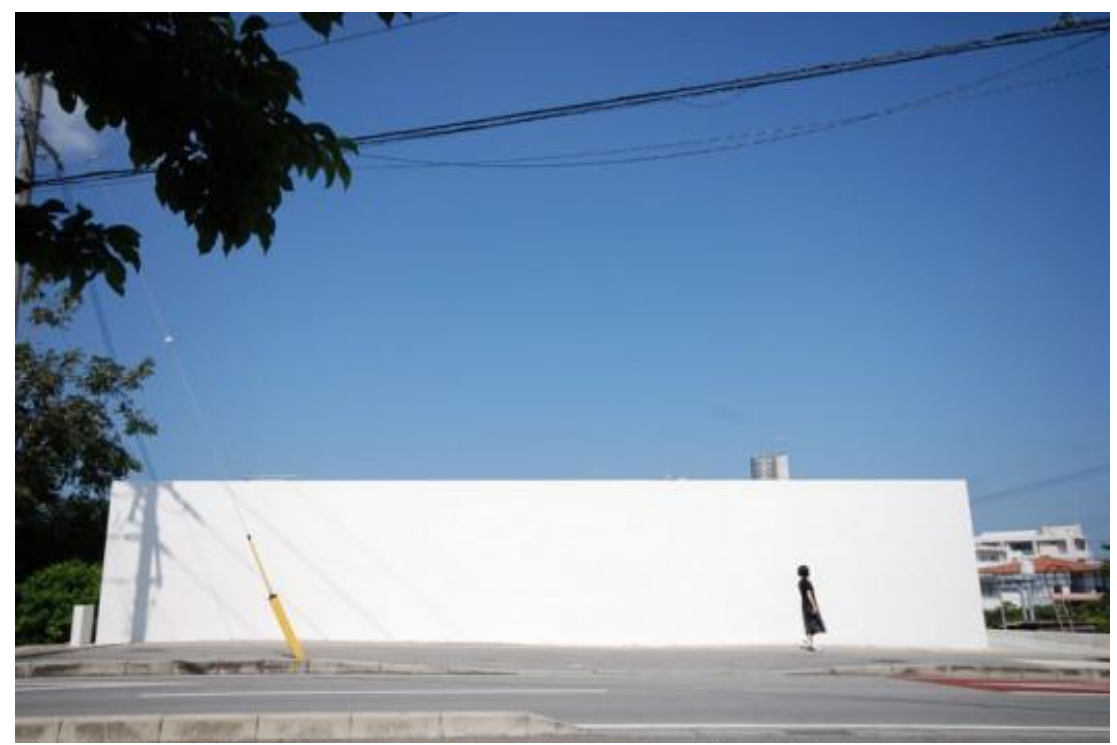

Figura 103. Perspectiva externa frontal. Fonte: https://bit.ly/2OVCEcK, acessado em 10/10/2017.

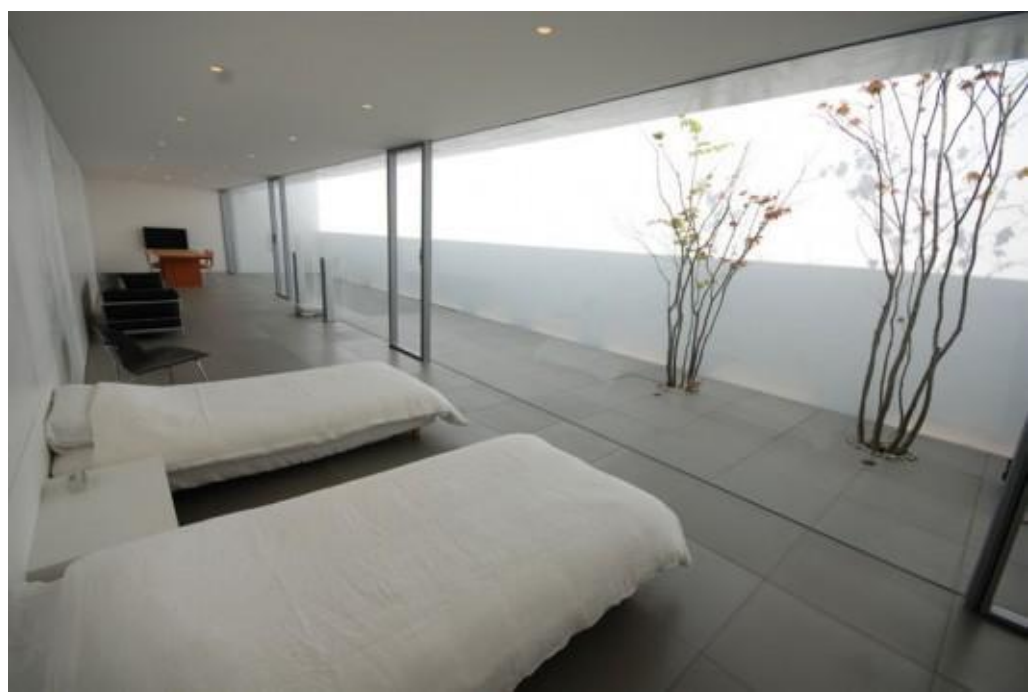

Figura 104. Perspectiva interna.

Fonte: https://bit.ly/2OVCEcK, acessado em 10/10/2017. 


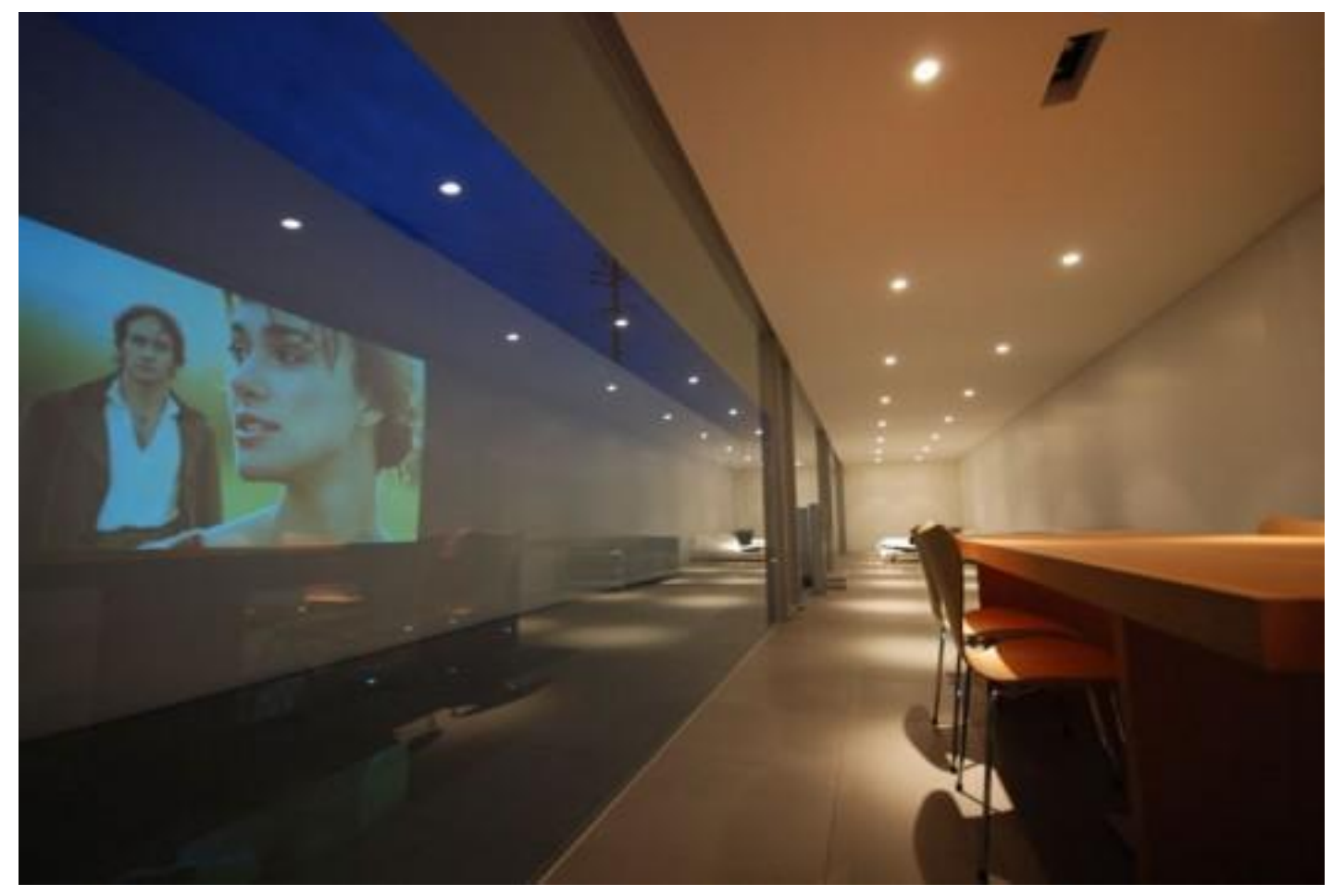

Figura 105. Perspectiva interna.

Fonte: https://bit.ly/2OVCEcK, acessado em 10/10/2017.

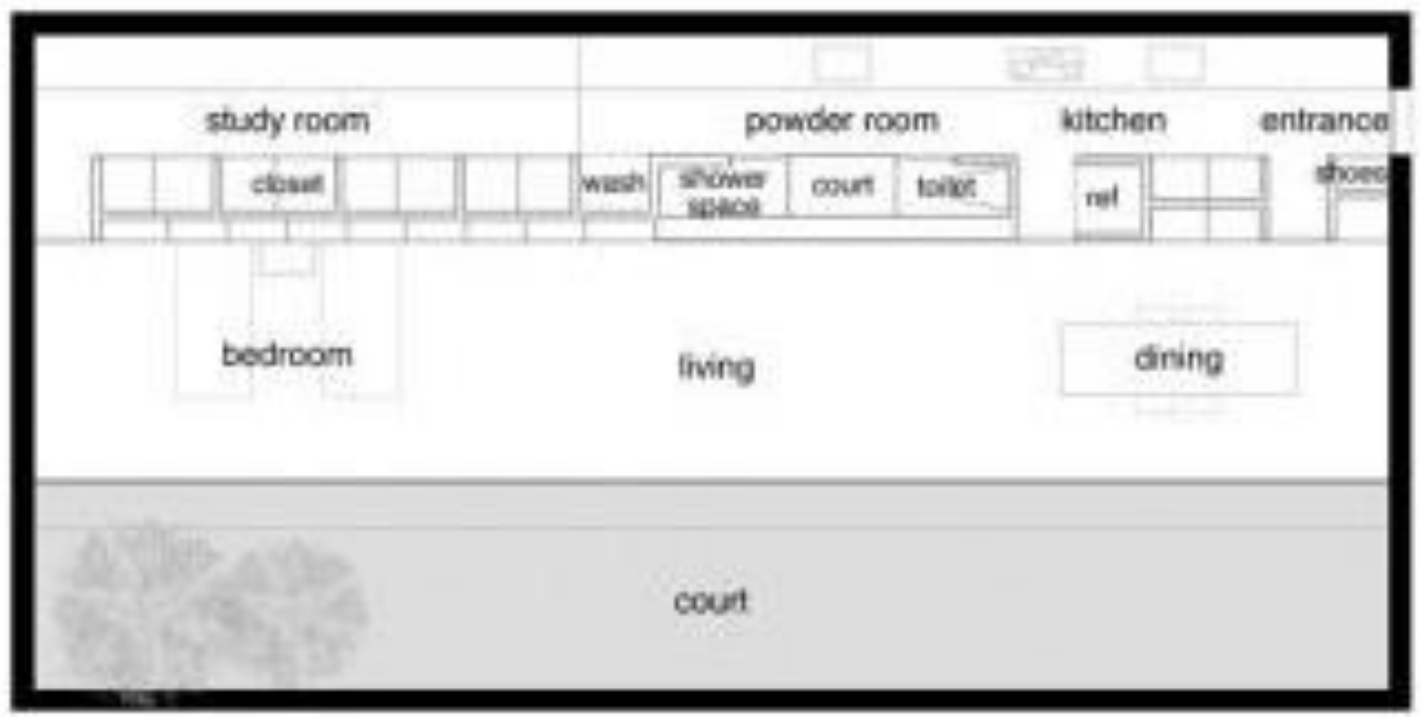

Figura 106. Planta baixa.

Fonte: https://bit.ly/2OVCEcK, acessado em 10/10/2017. 

construída: $144 \mathrm{~m}^{2}$. Área do terreno: $288 \mathrm{~m}^{2}$. Tipo de projeto: Residencial (Figuras $107 \mathrm{a}$ 111).

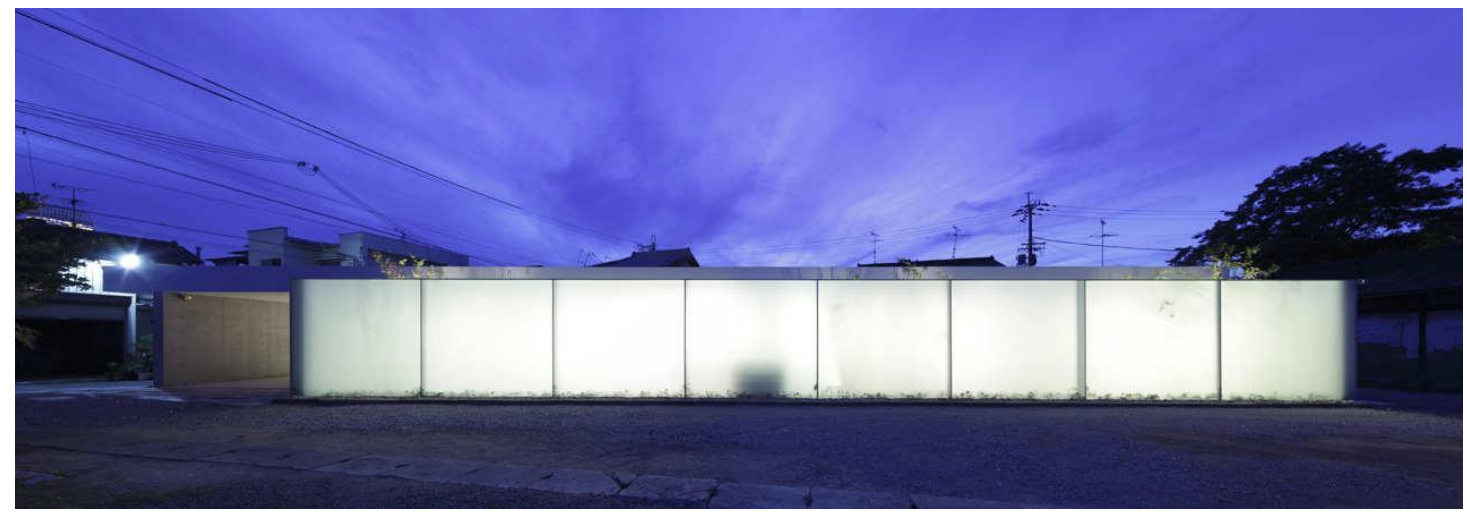

Figura 107. Perspectiva externa.

Fonte: https://bit.ly/2wcWR68, acessado em 10/10/2017.

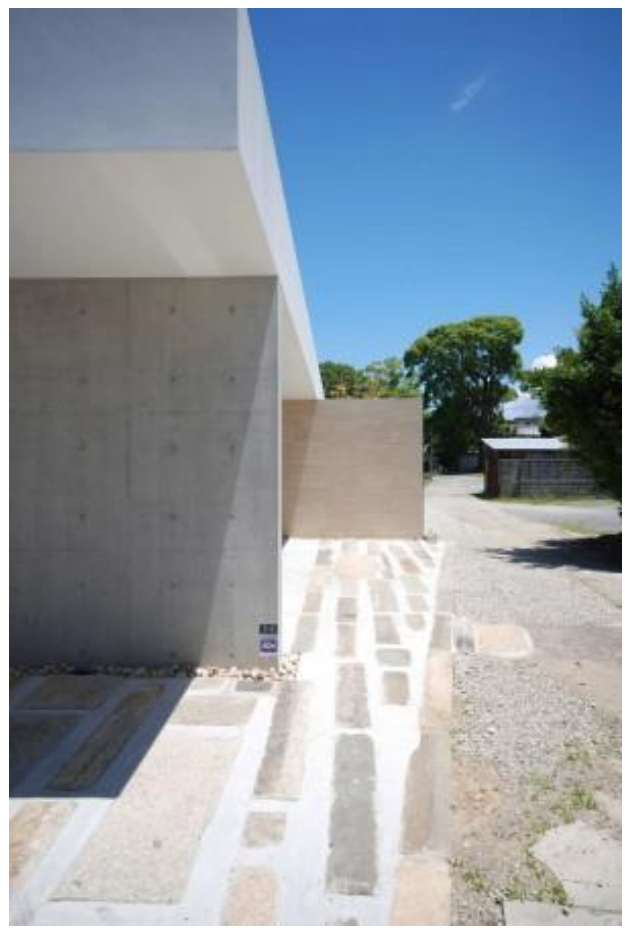

Figura 108. Perspectiva externa. 


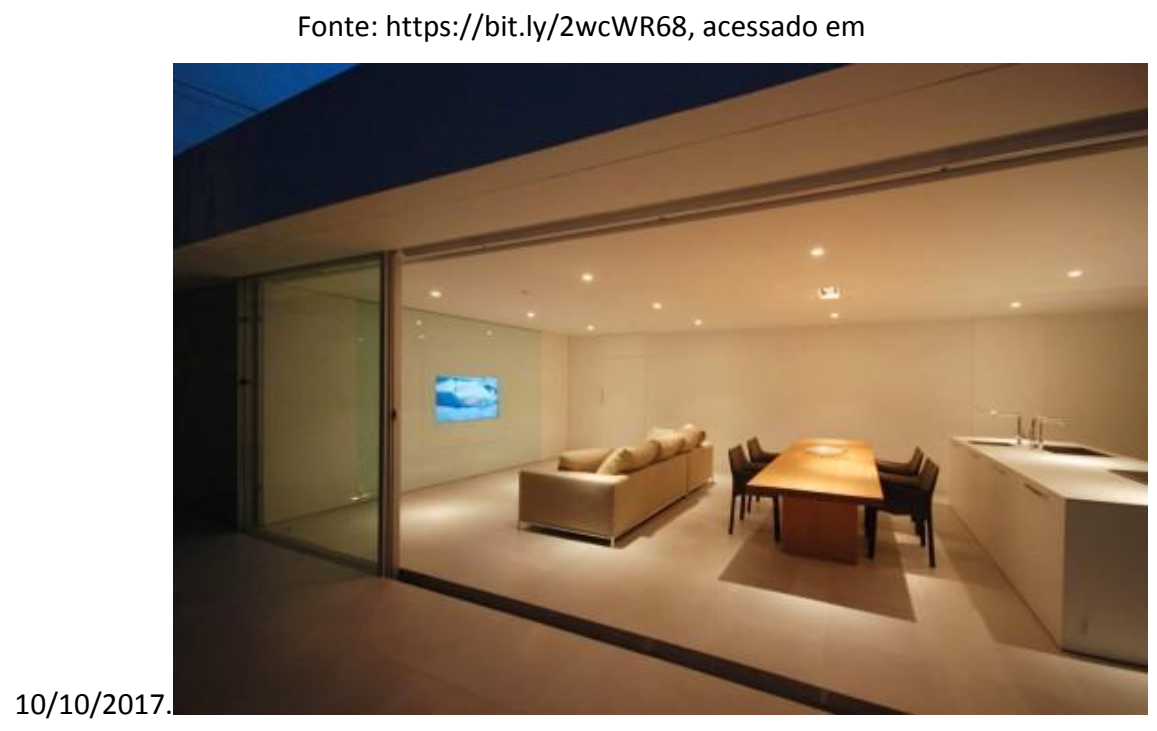

Figura 109. Perspectiva interna.

Fonte: https://bit.ly/2wcWR68, acessado em 10/10/2017.
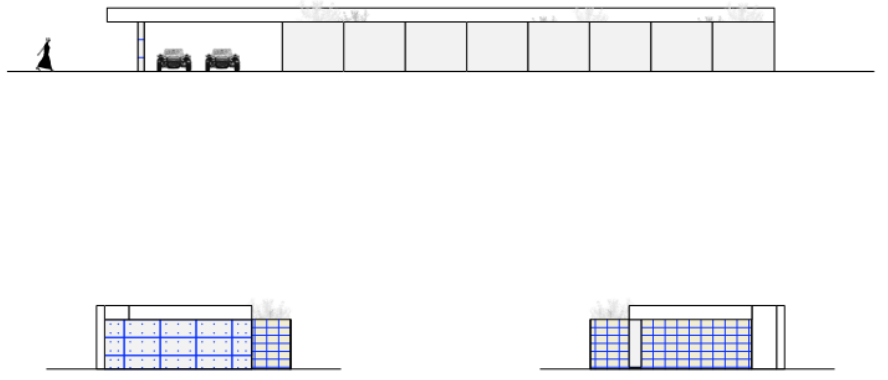

Figura 110. Fachadas.

Fonte: https://bit.ly/2wcWR68, acessado em 10/10/2017.

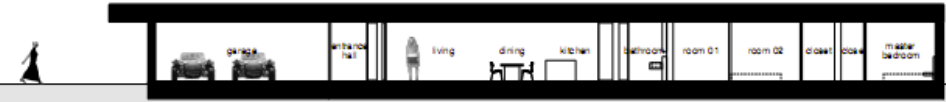


Por fim, como inegável estímulo e referência a este trabalho, a abordagem de Iñaki Ábalos em Boa-vida (2001), a qual apresenta uma análise com muita propriedade do filme "Meu Tio" (Mon Oncle), do cineasta Jacques Tati. Prova irrefutável de que é possível por meio do audiovisual dar luz a ensinamentos teóricos da arquitetura.

Outros estudos analisados foram referentes a construção da ideia das casas humildes, são apresentadas de maneira mais específica no Brasil através do livro de Gunter: Arquitetura Popular Brasileira (2005). A seguir transpomos alguns exemplos desse morar brasileiro em diferentes épocas e regiões do Brasil com aspectos caracteristicos que o livro nos traz.

\subsection{Moradia em tocas}

Das moradias em tocas, pesar de rastros humanos em cavernas, hoje tem-se o consenso de que dificilmente os homens habitaram as cavernas isso porque as cavernas são produtos da natureza e o homem empre preferiu submeter a natureza a suas necessidades (Figura 112).

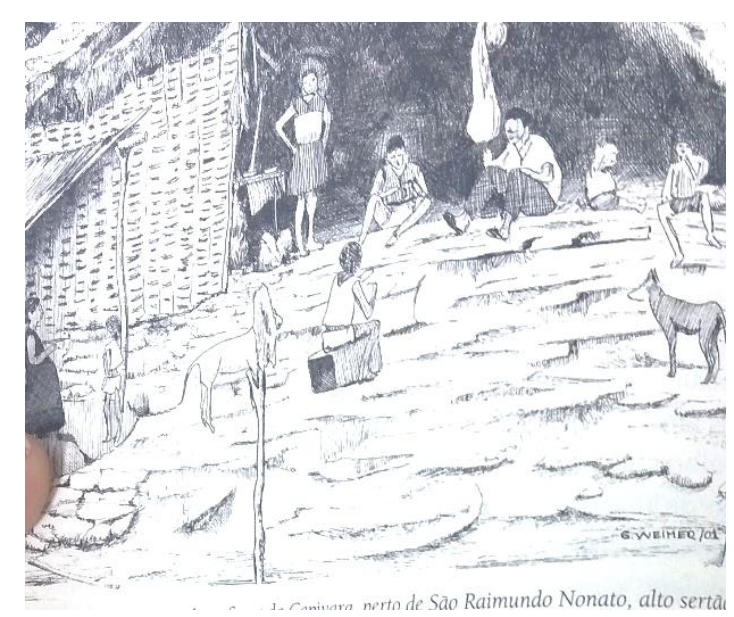

Figura 112. "Toca”habitada na serra da capivara, perto de São Raimundo Nonato. Fonte: Gunter, 2005.

\subsection{Moradia nas Caatingas}

Das morada nas caatingas, essas moradas são produto do que o homem tem acesso no sertão nordestino. O sertão nordestino possui longas estiagens, curto período de chuva e solo fértil. A habitação é construída com o que é encontrado em nessa região como troncos retorcidos. A característica das casas é característica da costa norte, plantas quadradas ou retangulares com três compartimentos formado por sala, corredor que liga a cozinha ao fundo, um quarto, chamado de alcova entre os dois ambientes e por vezes uma varanda. Cobertura vegetais de folhas de palmeiras e paredes de pau-a-pique.

Alguns fatos históricos e características levam a concluir a influência africana e europeia nas residências como a existência de algumas residências sem janelas como as de povos na África e casas com pequenas janelas, depois dos africanos serem obrigados a abrias pelos europeus. Foram feitas casas geminadas comuns em aldeias nortes angolanos. 
Contudo outras inovações foram aceitas como a troca da cobertura de palha para cerâmica, uso de quatro aguas, e uso de frontões (Figuras 113 a 117).

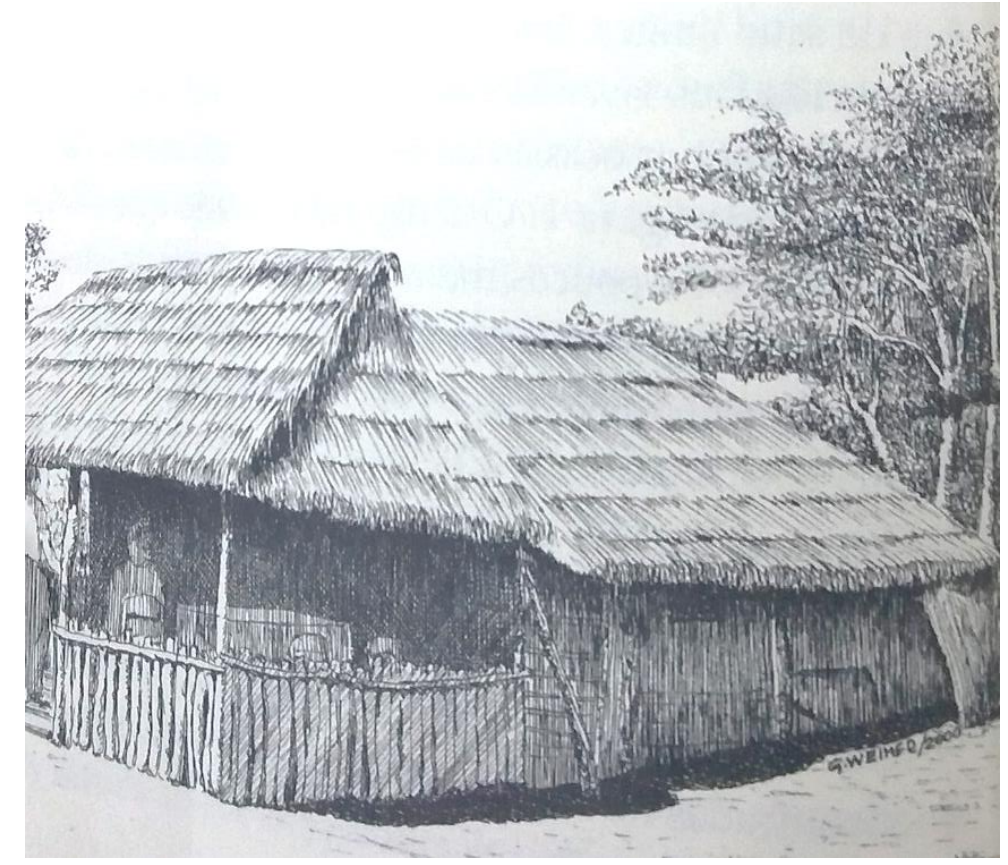

Figura 113. "Bar" no sertão nordestino. Fonte: Gunter, 2005.

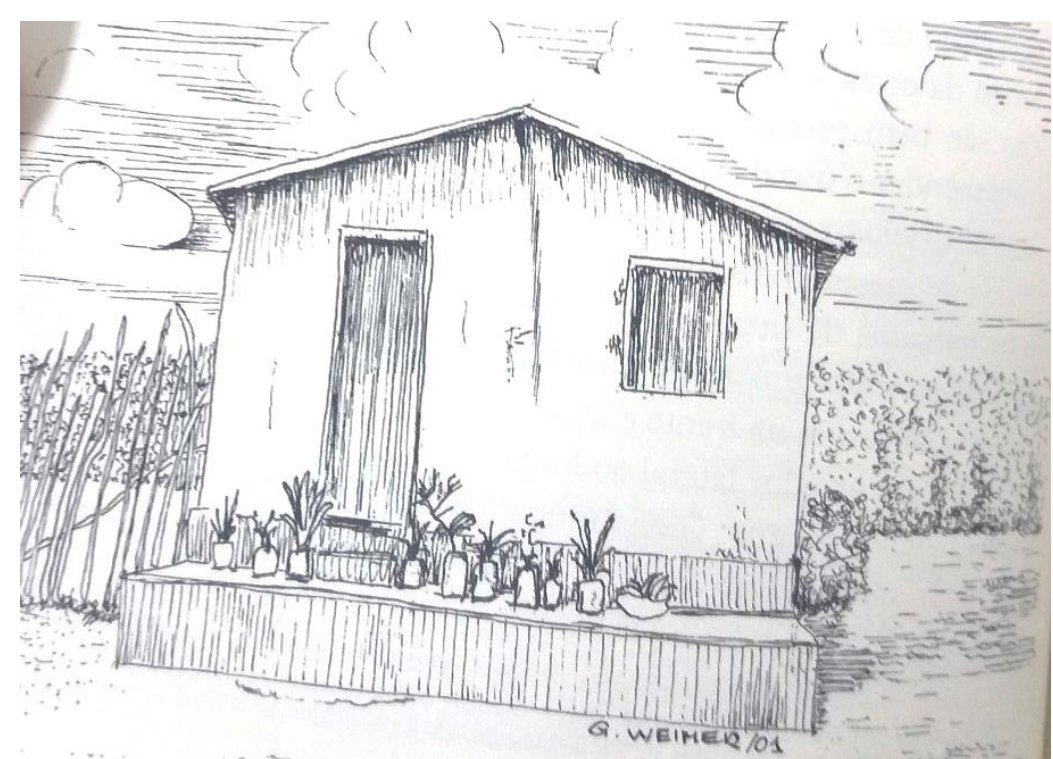

Figura 114. Casa nos arredores de São Raimundo Nonato, no alto sertão do Piauí. Fonte: Gunter, 2005. 


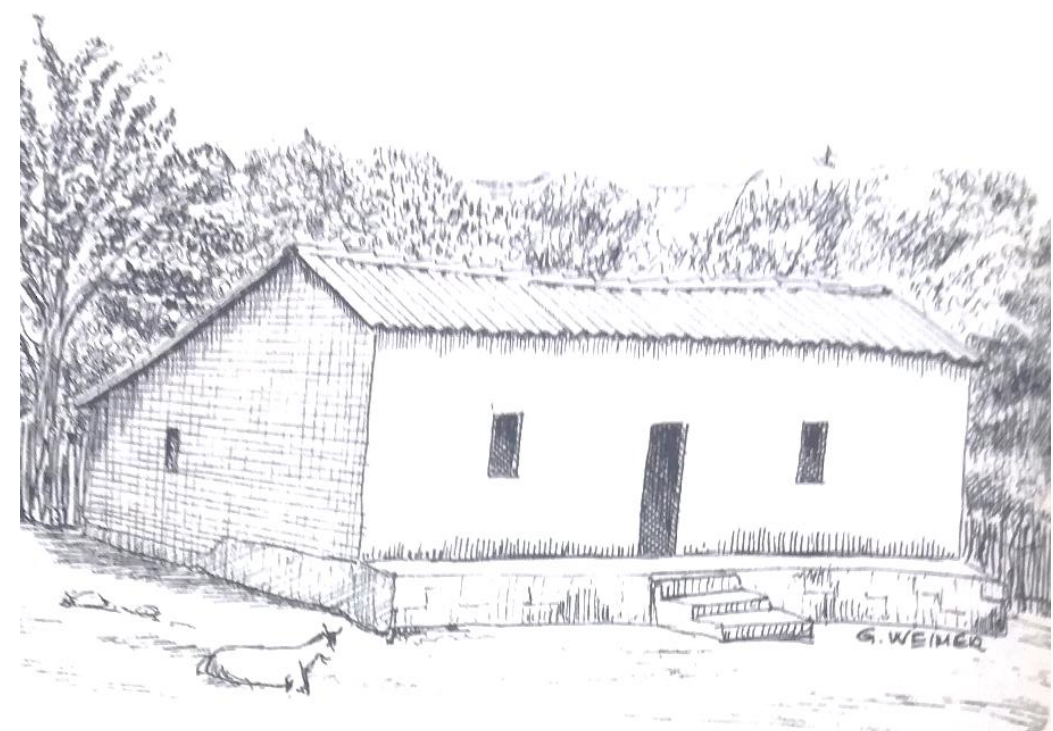

Figura 115. Casa nos arredores de São Raimundo Nonato, no alto sertão do Piauí. Fonte: Gunter, 2005.

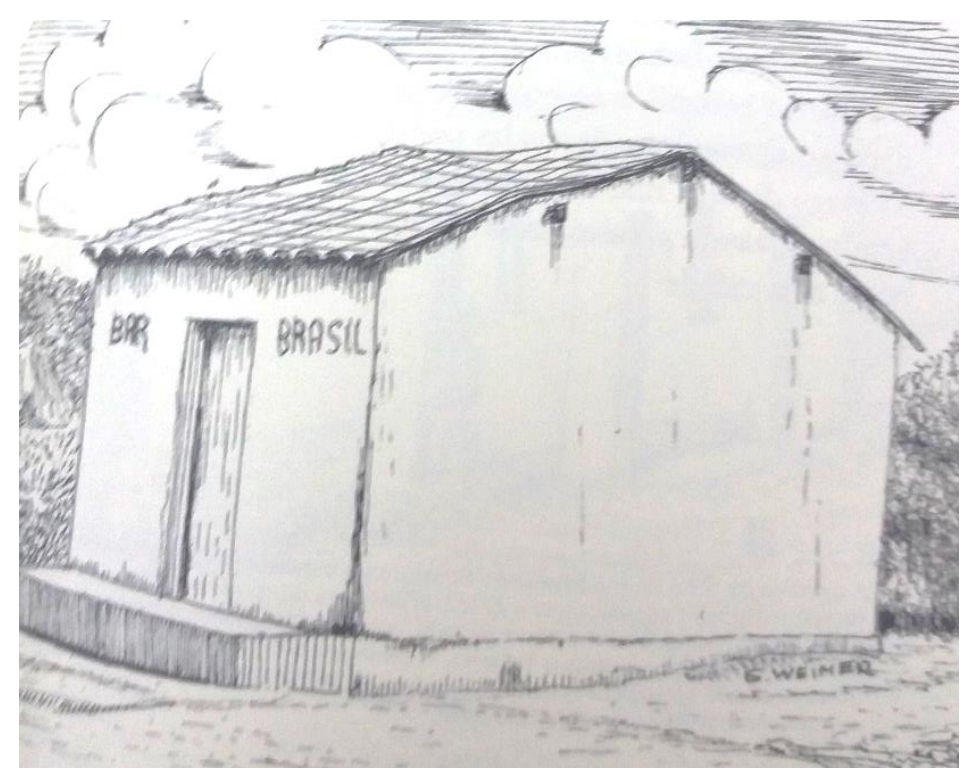

Figura 116. Casa no sítio do Mocó, São Raimundo onato, Piauí. Fonte: Gunter, 2005.

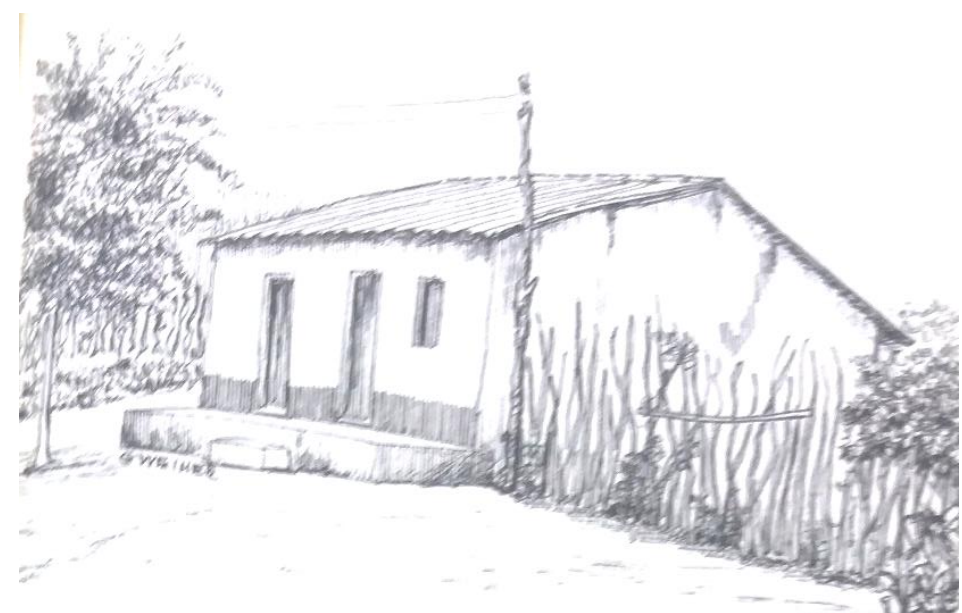

Figura 117. Casa no sítio do Mocó, São Raimundo onato, Piauí. Fonte: Gunter, 2005. 


\subsection{Moradia dos areais}

Das morada dos areais, é corriqueiro a construção de casas de pescadores e abrigos para barcos pelo litoral brasileiro. Dormem-se em redes. A cobertura é feita de palha de buriti e que servem para vedação, não chegam a 1,5 $\mathrm{m}$ de altura conforme estabelece a boa técnica indígena. Essas habitações são idênticas a de ancestrais angolanos (Figuras 118 a 129).

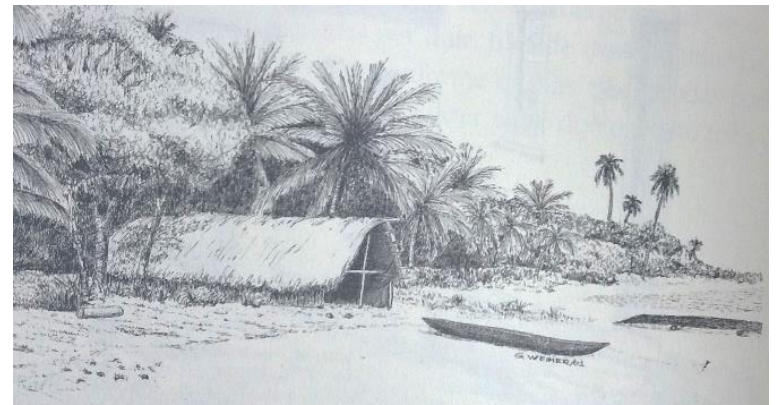

Figura 118. Casa de pescador com abrigo de barco, no faz do rio Real. Fonte: Gunter, 2005.

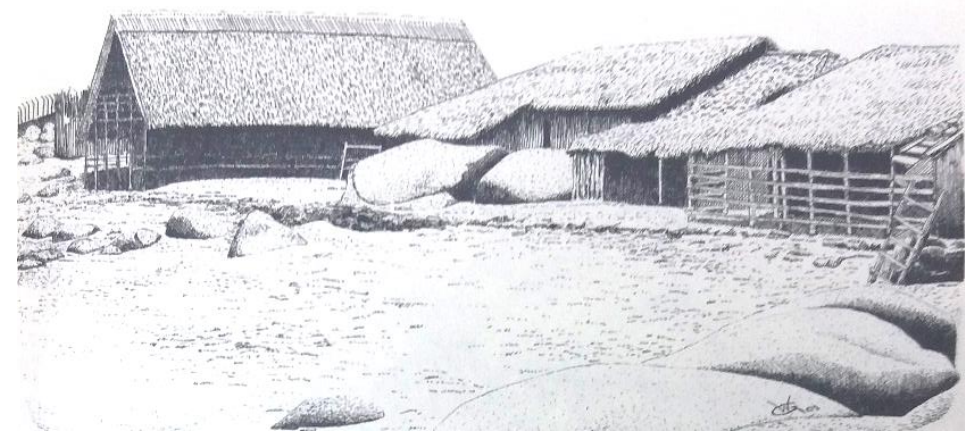

Figura 119. Casas de pescadoresna praia da Pedra do Sal, Piauí. Fonte: Gunter, 2005.

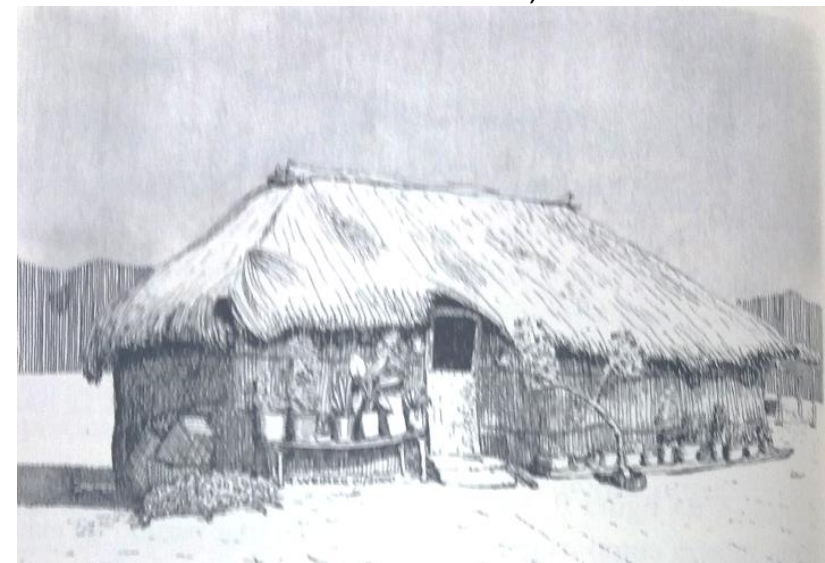

Figura 120. Casa de pescador na praia do Caburé, Lençóis Maranhenses. Fonte: Gunter, 2005. 


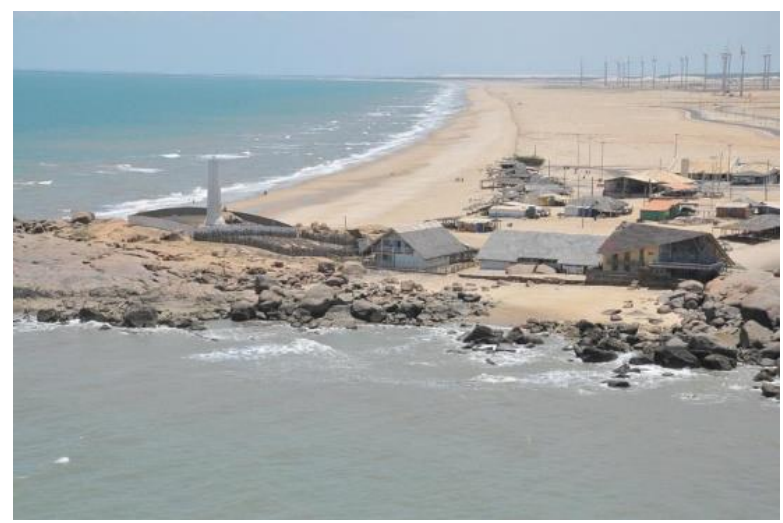

Figura 121. urbanização da orla da Pedra do Sal. Fonte: https://bit.ly/2N6r3qJ, acessado em 03/03/2018.

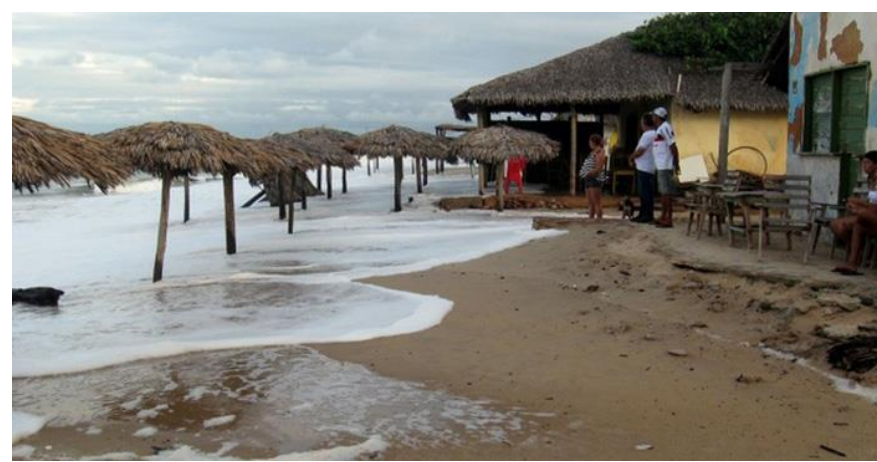

Figura 122. A orla da praia Pedra do Sal, em Parnaíba, Fonte: https://bit.ly/2N4Oz7u, acessado em 03/03/2018.

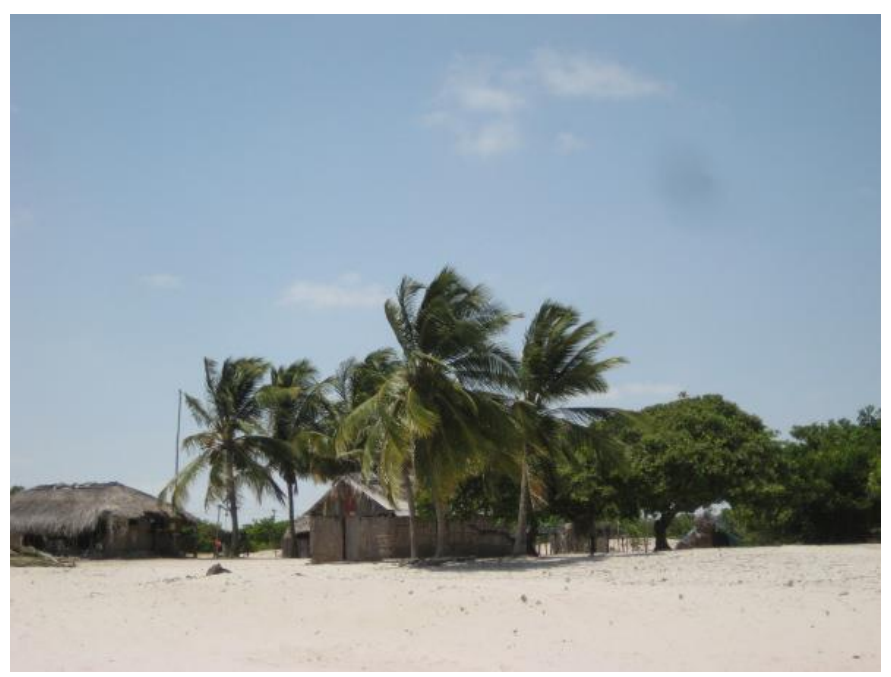

Figura 123. O Parque Nacional dos Lençóis Maranhenses Fonte: https://bit.ly/2Bx9mPU, acessado em 17/03/2018. 


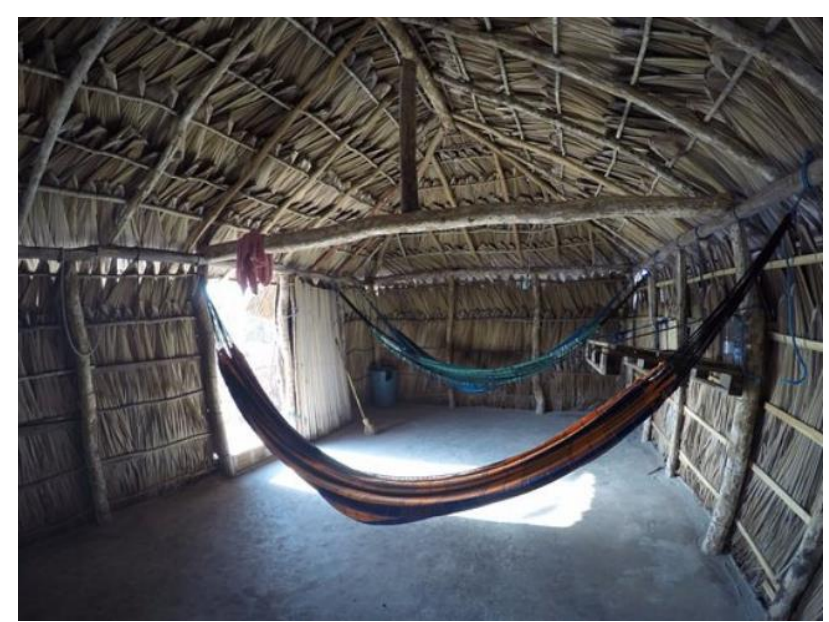

Figura 124. Perspectiva interna.

Fonte: https://bit.ly/2Bx9mPU, acessado em 17/03/2018.

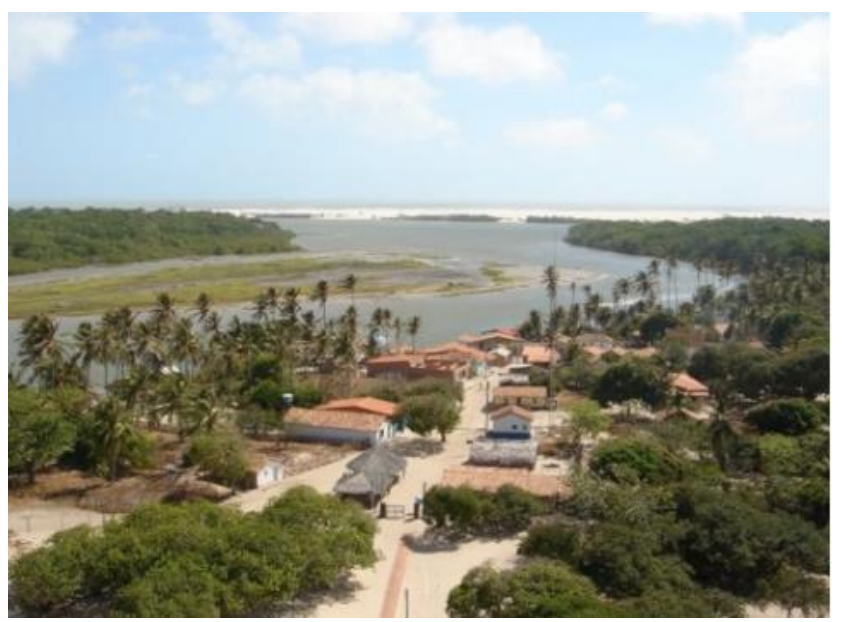

Figura 125. O Parque Nacional dos Lençóis Maranhenses Fonte: https://bit.ly/2Bx9mPU, acessado em 17/03/2018.

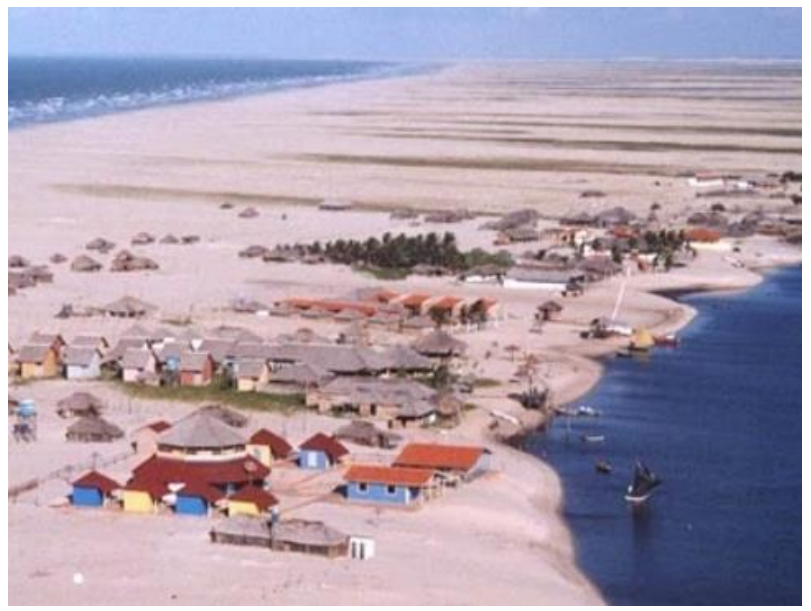

Figura 126. O Parque Nacional dos Lençóis Maranhenses Fonte: https://bit.ly/2Bx9mPU, acessado em 17/03/2018. 


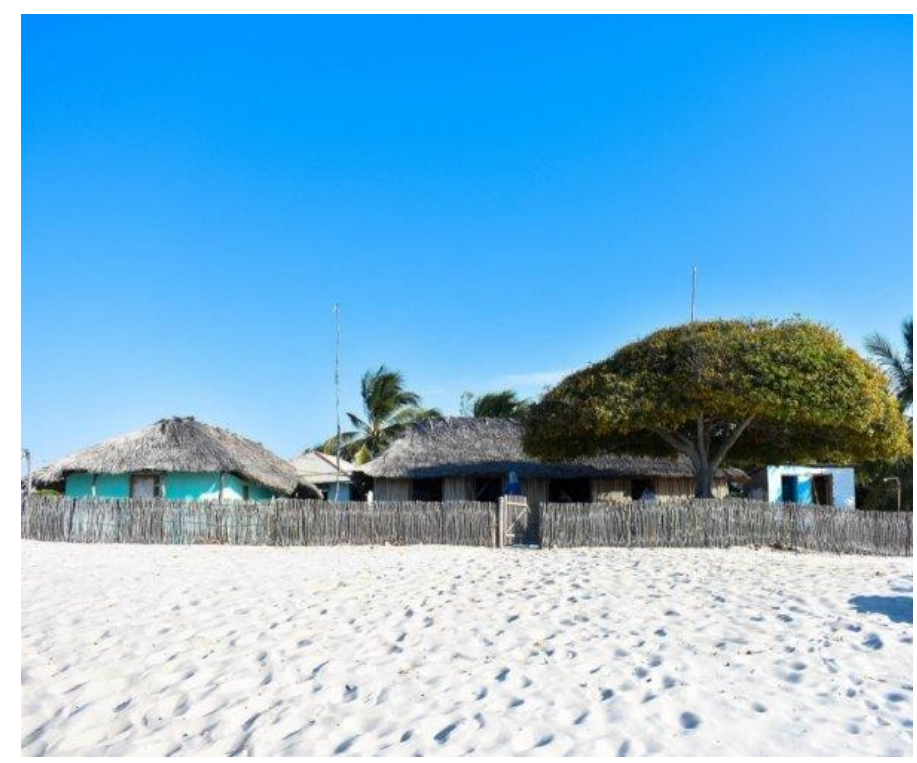

Figura 127. O Parque Nacional dos Lençóis Maranhenses Fonte: https://bit.ly/1ND9gPV, acessado em 17/03/2018.

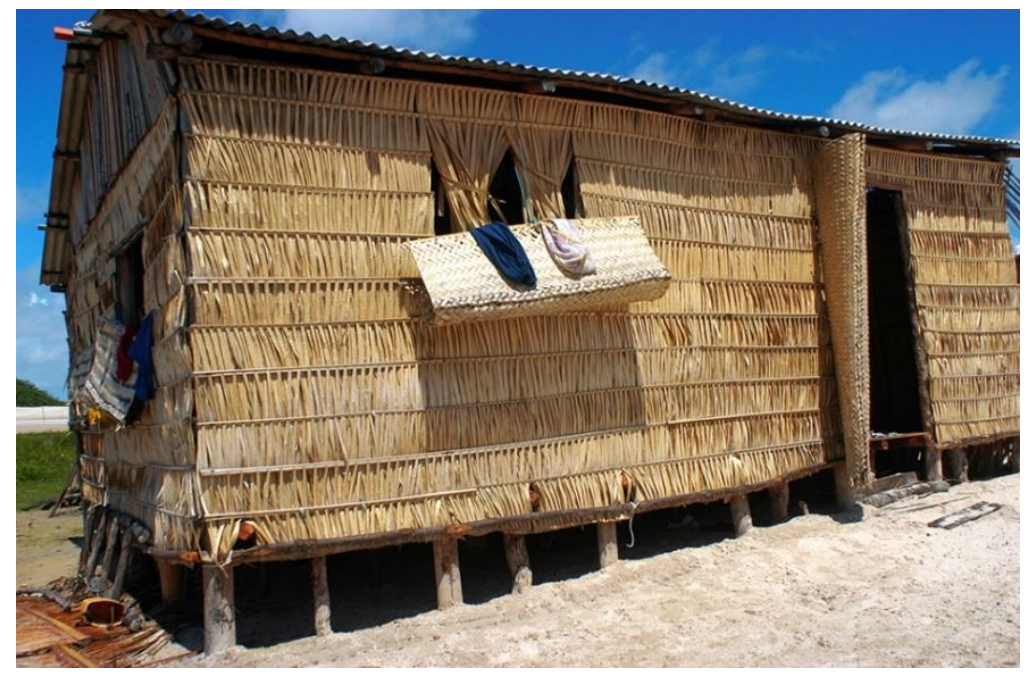

Figura 128. Litoral norte do Maranhão. As casa da Ilha dos Lençóis. Fonte: https://bit.ly/2wh73dV, acessado em 17/03/2018.

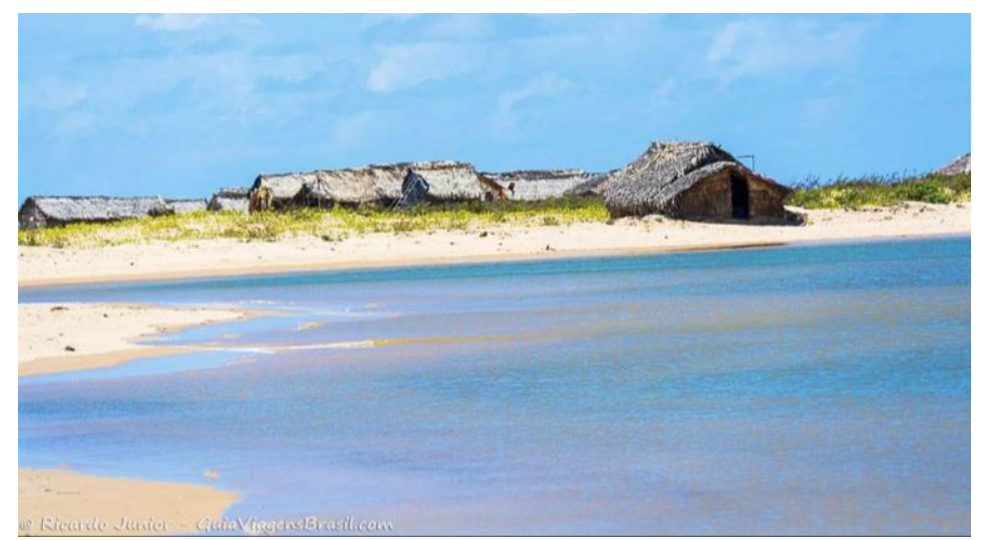

Figura 129. praia paradisíaca a das casa de pescadores, casas rústicas como uma oca, Foz Rio São Francisco, em Alagoas, Brasil. Fonte: https://bit.ly/1ND9gPV, acessado em 17/03/2018. 


\subsection{Moradia dos coqueirais}

Das casas dos coqueirais, as descrições da casa do pescador também servem para as casas dos coqueirais que se encontram entre coqueirais. São casas construídas no meio dos coqueirais que acompanham a orla marítima do país. Hoje essa paisagem pertence ao passado.

As características dessas casas podem indicar que região africana influenciou essa área. Tanto que depois de fazer estudos sobre a evolução da arquitetura africana, as fotografias tiradas por Gunter se assemelhavam as tiradas das casas do norte de Moçambique (Figuras 130 e 136)

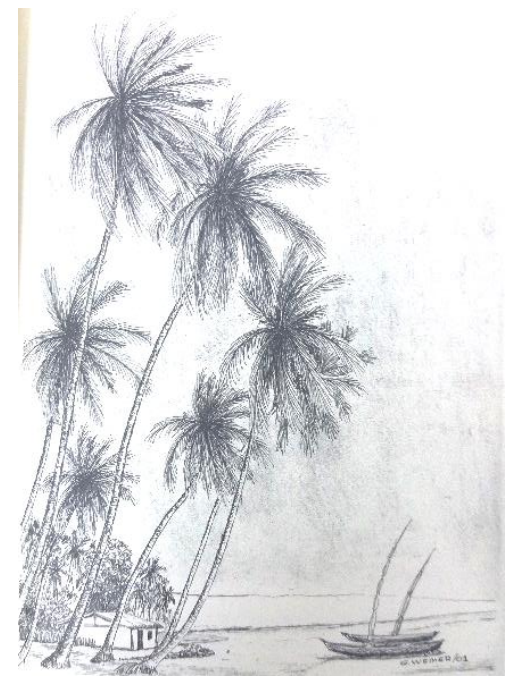

Figura 130. Casa de pescador na praia de Areia Branca, Rio Grande do Norte. Fonte: Gunter, 2005.

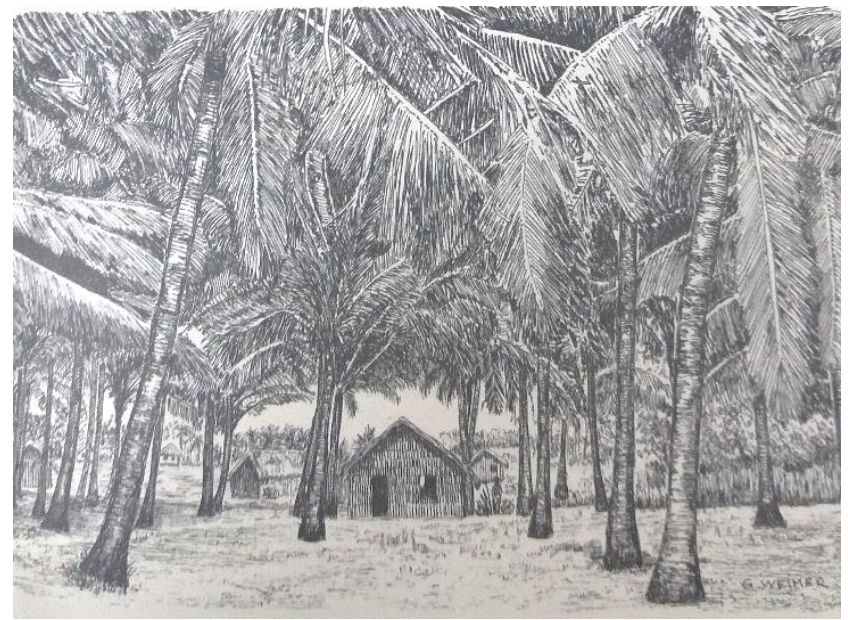

Figura 131. Mocambo em Cabedelo, Pernambuco. Fonte: Gunter, 2005. 


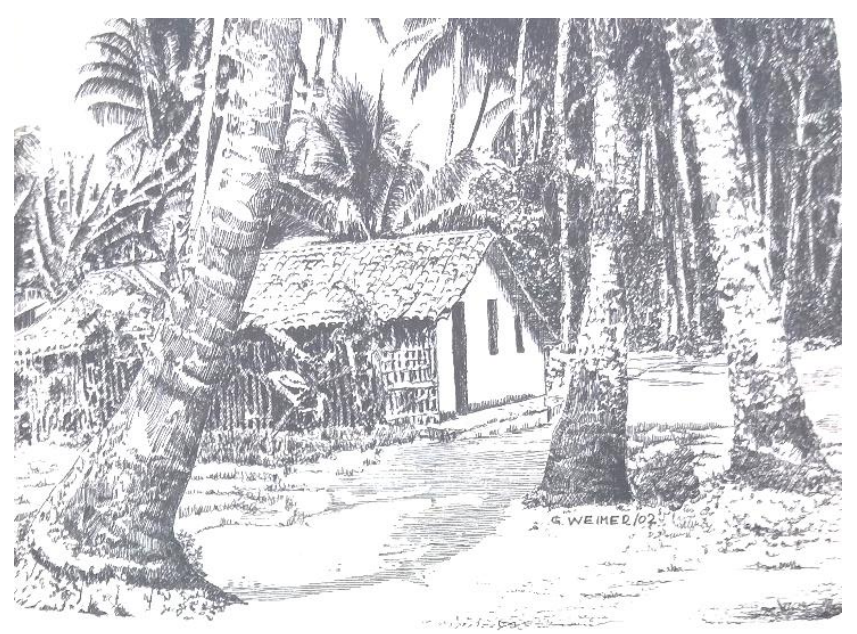

Figura 132. Casa de pescador em Barra do pote, Itaparica, Bahia. Fonte: Gunter, 2005

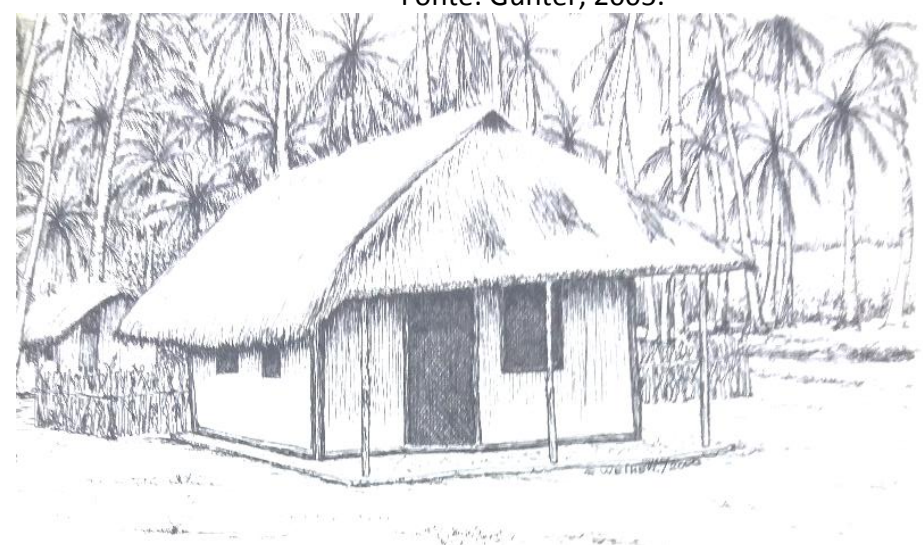

Figura 133. Mocambo de Recife de tipologia moçambicana ou angolana. Fonte: Gunter, 2005.

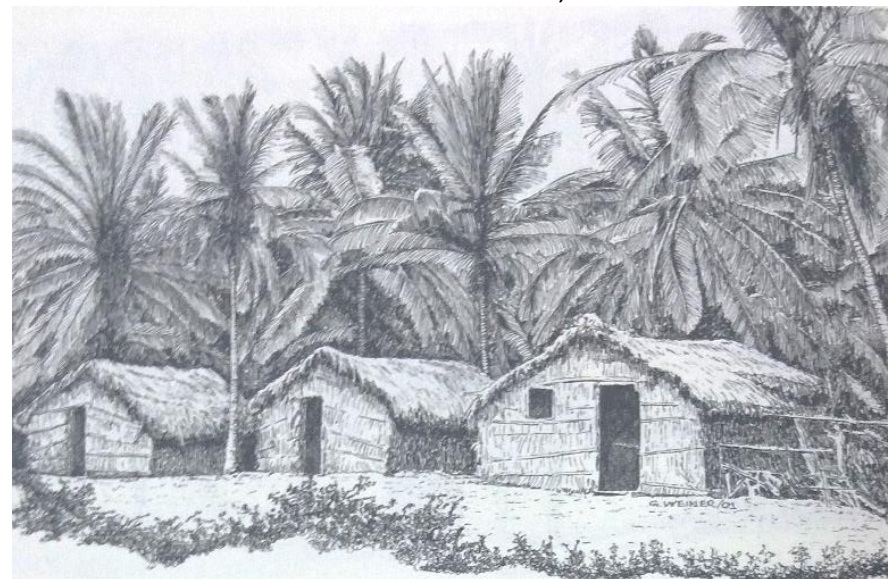

Figura 134. Mocambos da praia do Arpoador, Ceará. Fonte: Gunter, 2005. 


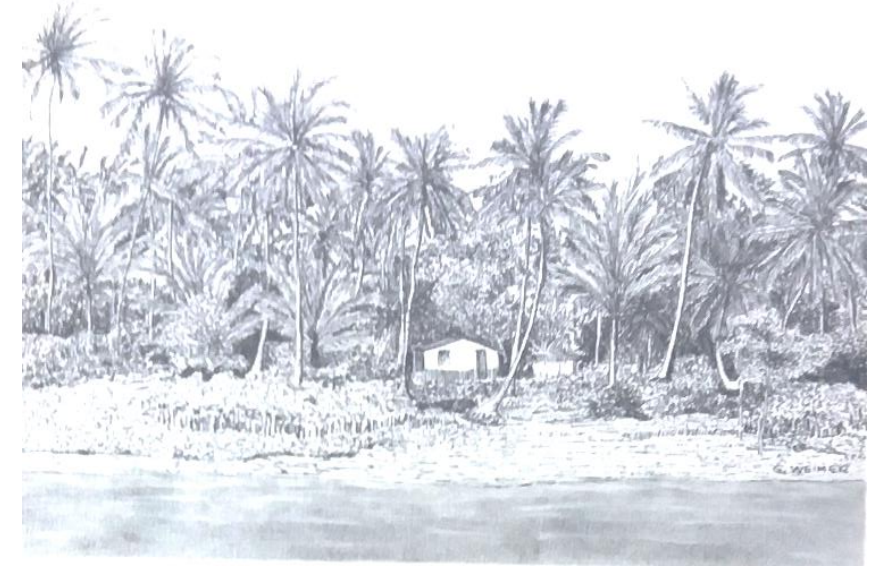

Figura 135. Casa na ilha de Caviana Amapá. Fonte: Gunter, 2005.

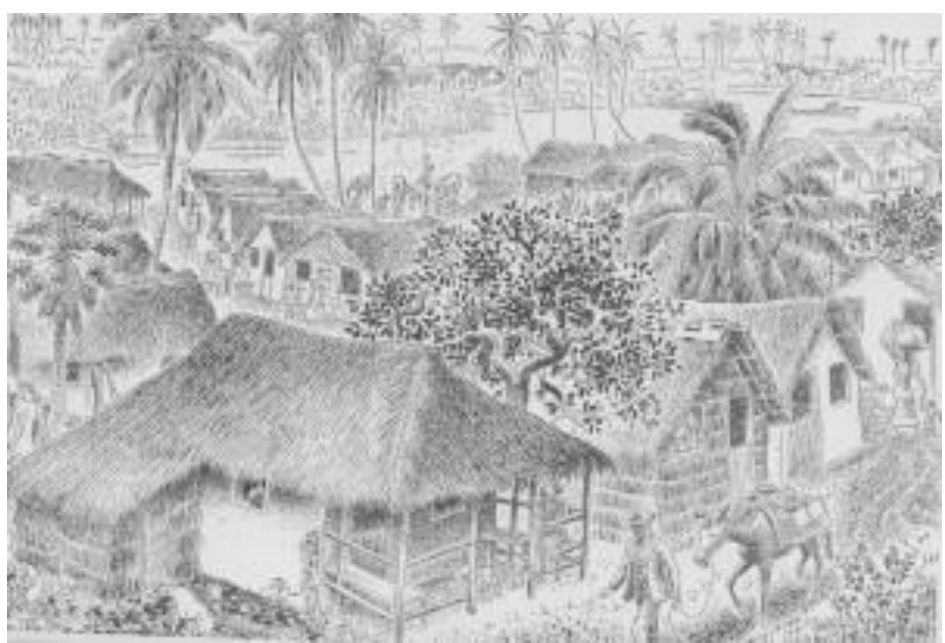

Figura 136. Mocambo - habitação rústica no Brasil. (desenho de percy lau) Fonte: http://www.consciencia.org/mocambo-habitacao-rustica-no-brasil, acessado em 17/04/2018.

\subsection{Moradia dos mangues}

Das casas dos mangues, os mangues são formações típicas dos litorais tropicais. Plantas adaptadas a água salgada. Crescen na beira d'água nas desembocaduras dos rios e nas areias da praia (Figuras 137 a 140).

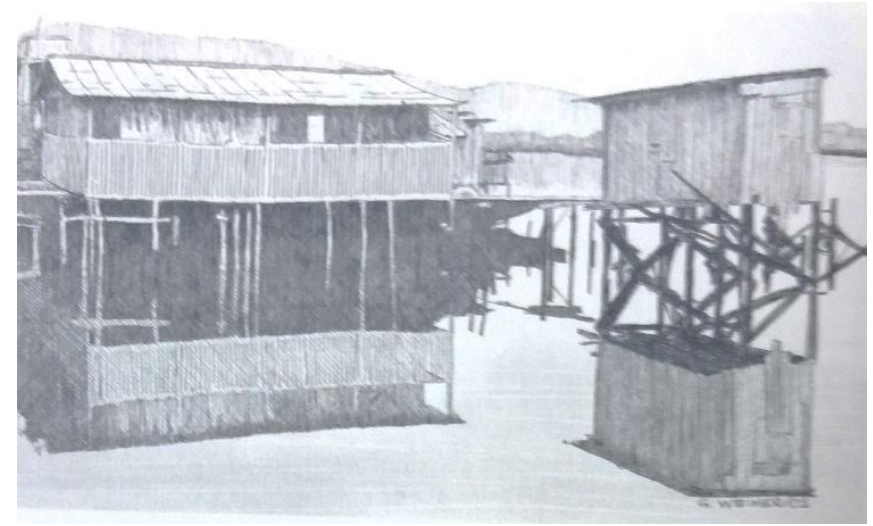

Figura 137. Palafita nos arredores de Vitória, Espirito Santo. Fonte: Gunter, 2005. 


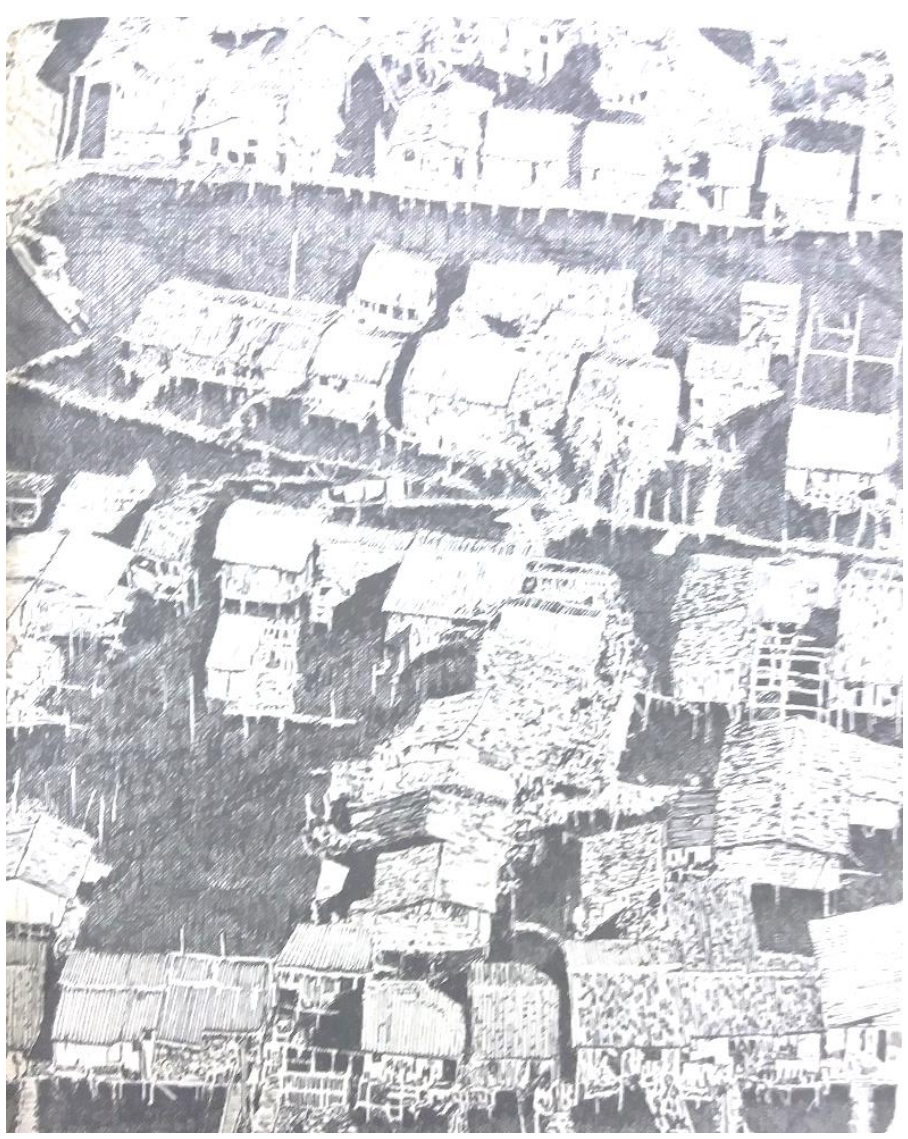

Figura 138. Palafita dos Alagados de salvador, uma tradição que teima não morrer. Fonte: Gunter, 2005.

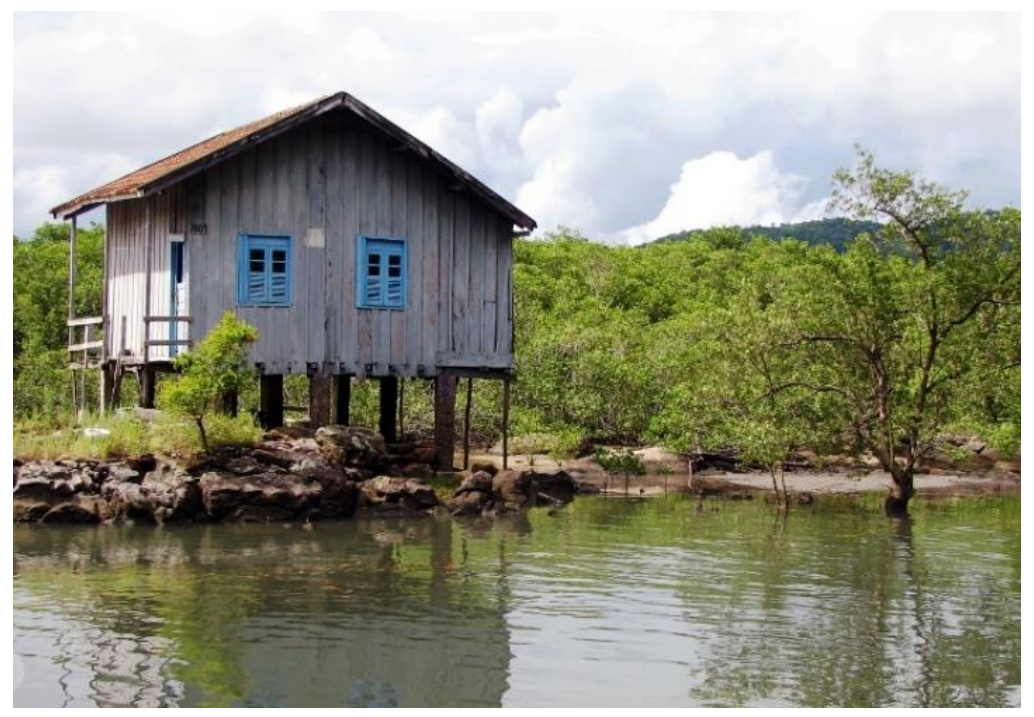

Figura 139. Casa dos mangues.

Fonte: https://bit.ly/2OWarT7, acessado em 17/04/2018. 


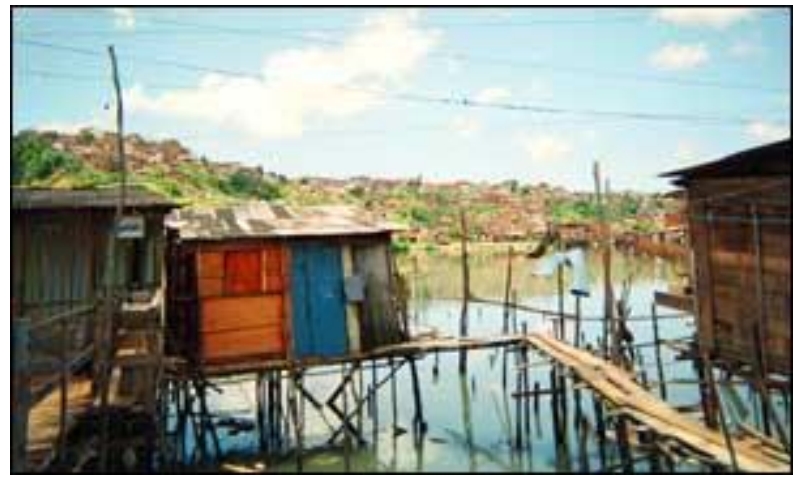

Figura 140. Casa dos mangues. Região de Alagados-BA não tem limites definidos. Fonte: https://bbc.in/2Ms6U2b, acessado em 17/04/2018.

\subsection{Moradia em pântanos}

Das casas em pântanos, são uma variante das casas em mangues (Figuras 141 a 149).

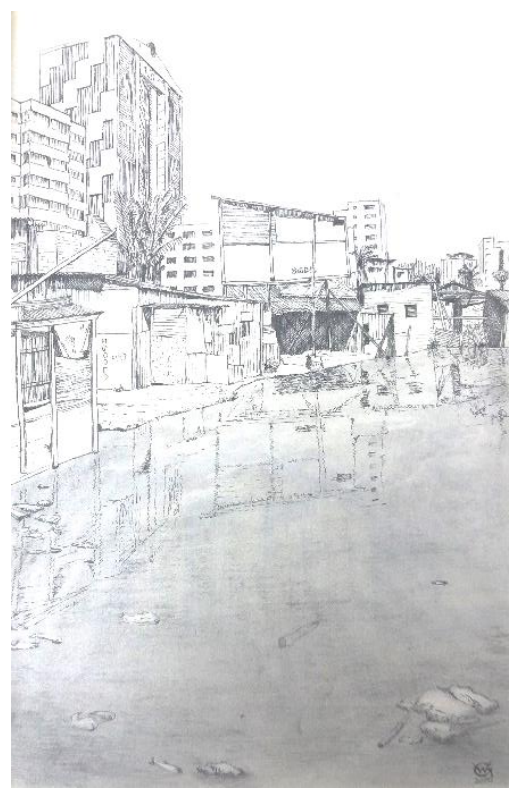

Figura 141. Os barracos da lagoa Costa Azul, Salvador, Bahia. Fonte: Gunter, 2005.

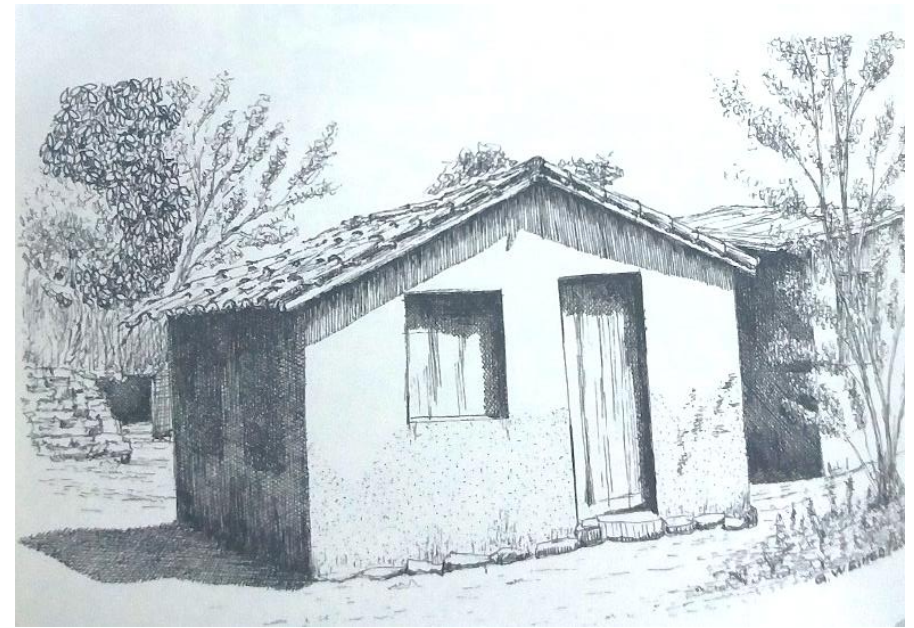


Figura 142. Casa de origem africana em Pocone, pantanal mato grossense. Fonte: Gunter, 2005.

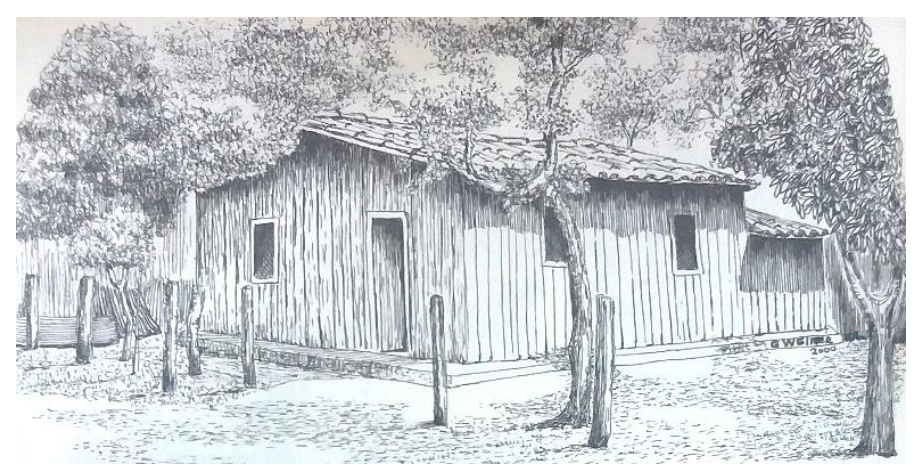

Figura 143. Casa de origem africana em Pocone, pantanal mato grossense. Fonte: Gunter, 2005.

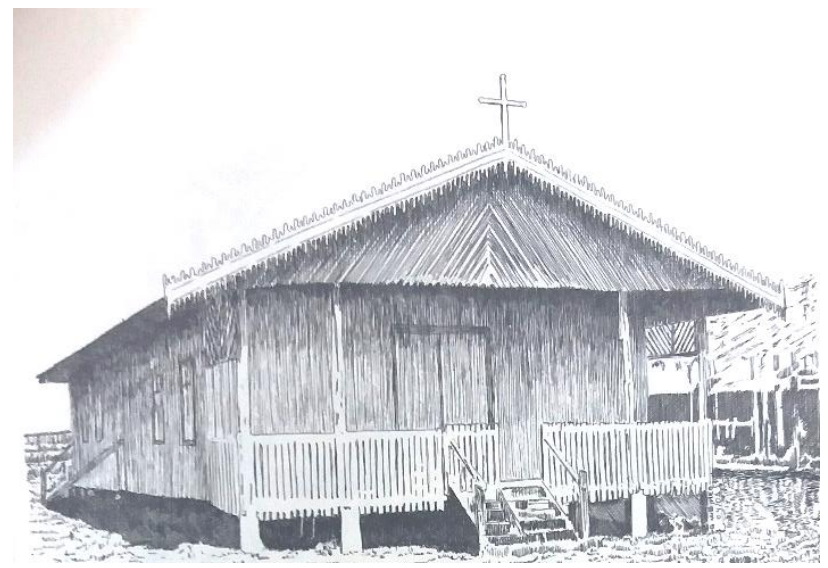

Figura 144. Igreja de madeira em Cachoeira do Arari, ilha de Marajó. Fonte: Gunter, 2005.

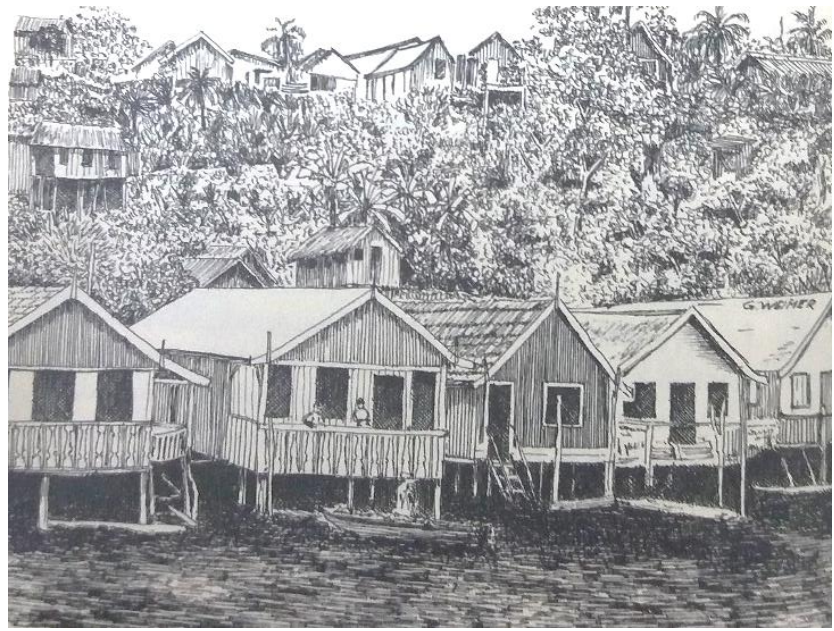

Figura 145. Palafita de casas operárias na periferia de Manaus. Fonte: Gunter, 2005. 


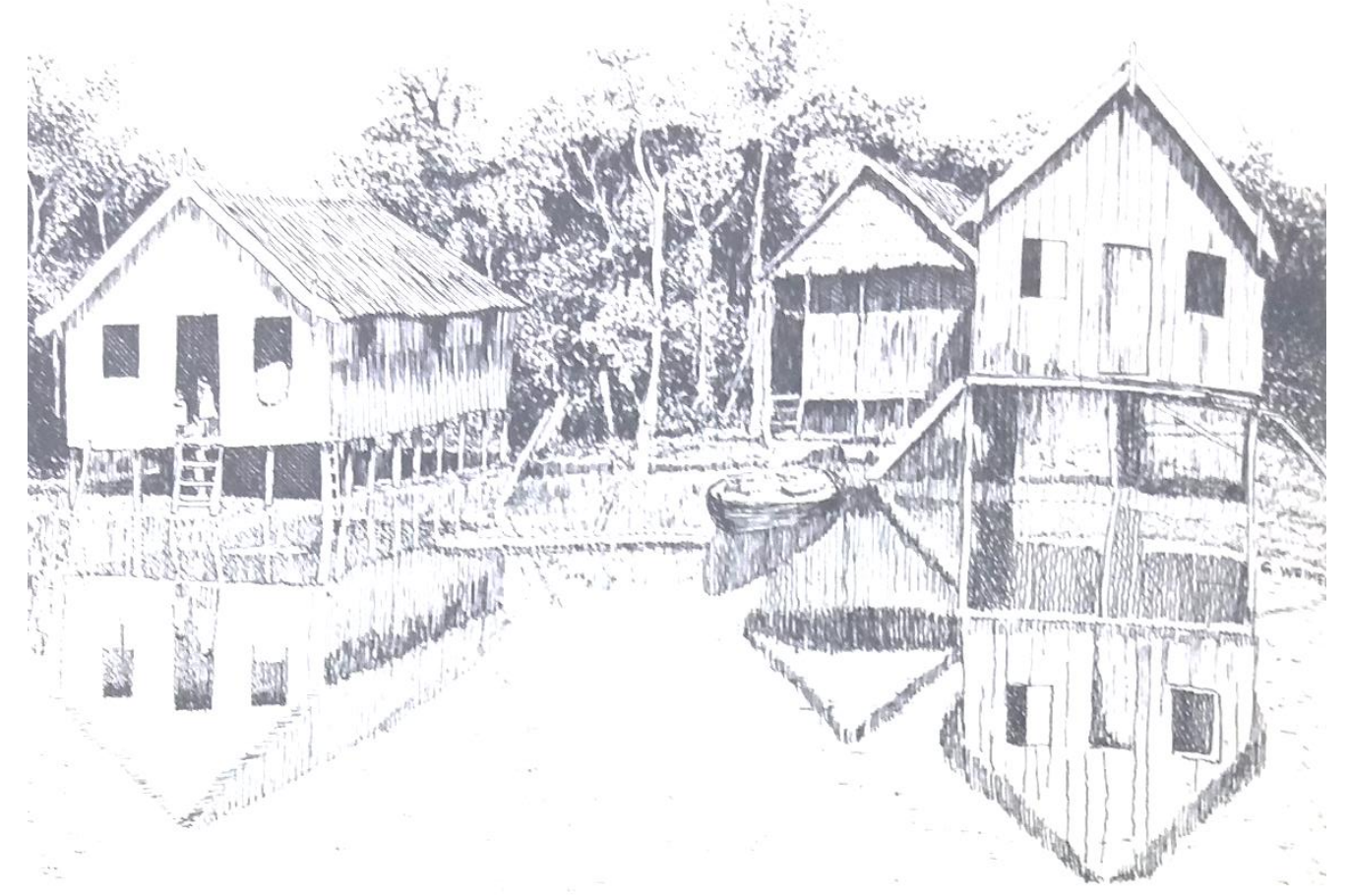

Figura 146. Casas ribeirinhas no rio negro, Amazonas. Fonte: Gunter, 2005.

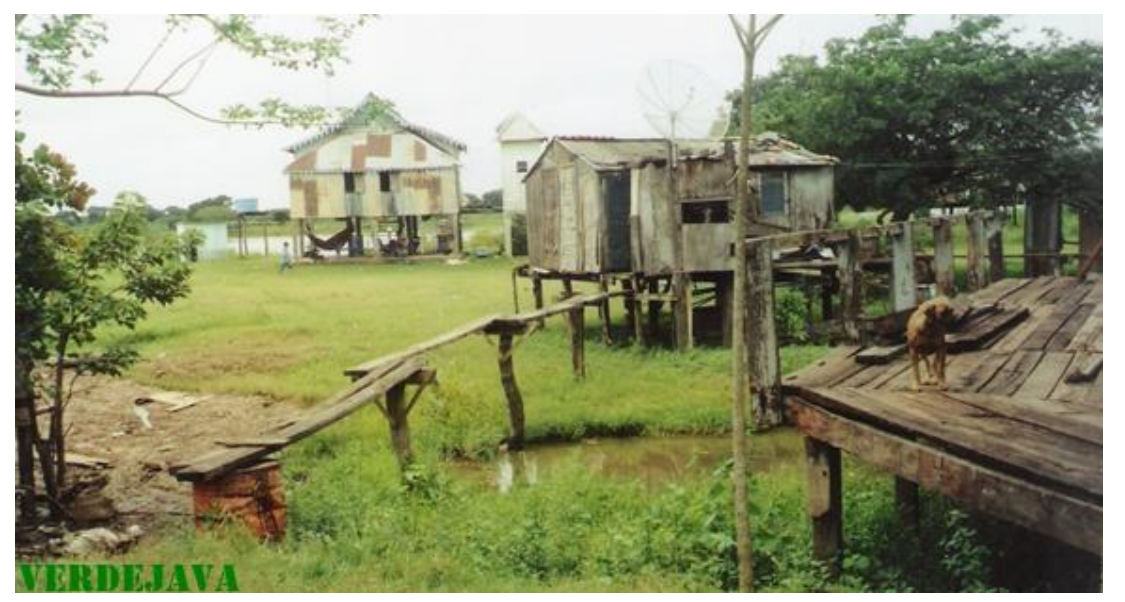

Figura 147. O novo cenário - Palafitas dos Alagados - Uma favela em cima do mar. Fonte: https://bit.ly/2BtxFhw, acessado em 17/04/2018. 


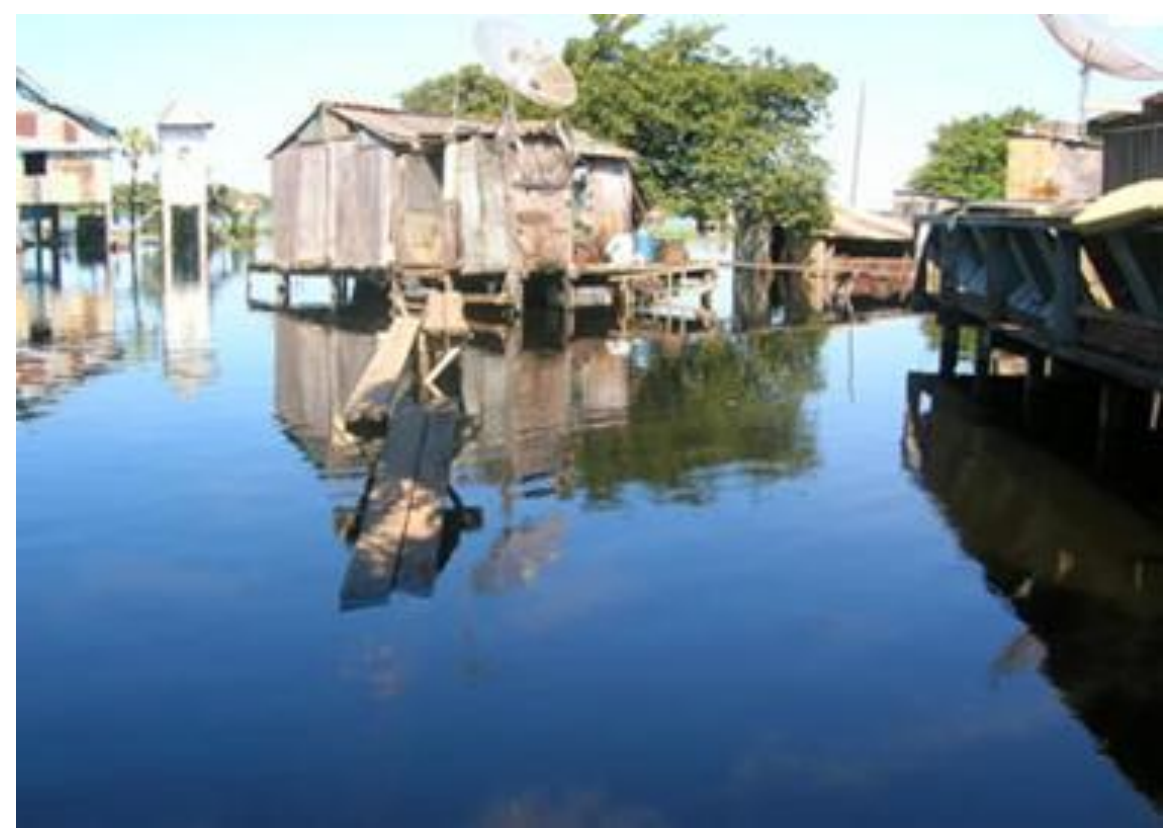

Figura 148. O novo cenário - Palafitas dos Alagados - Uma favela em cima do mar. Fonte: https://bit.ly/2BtxFhw, acessado em 17/04/2018.

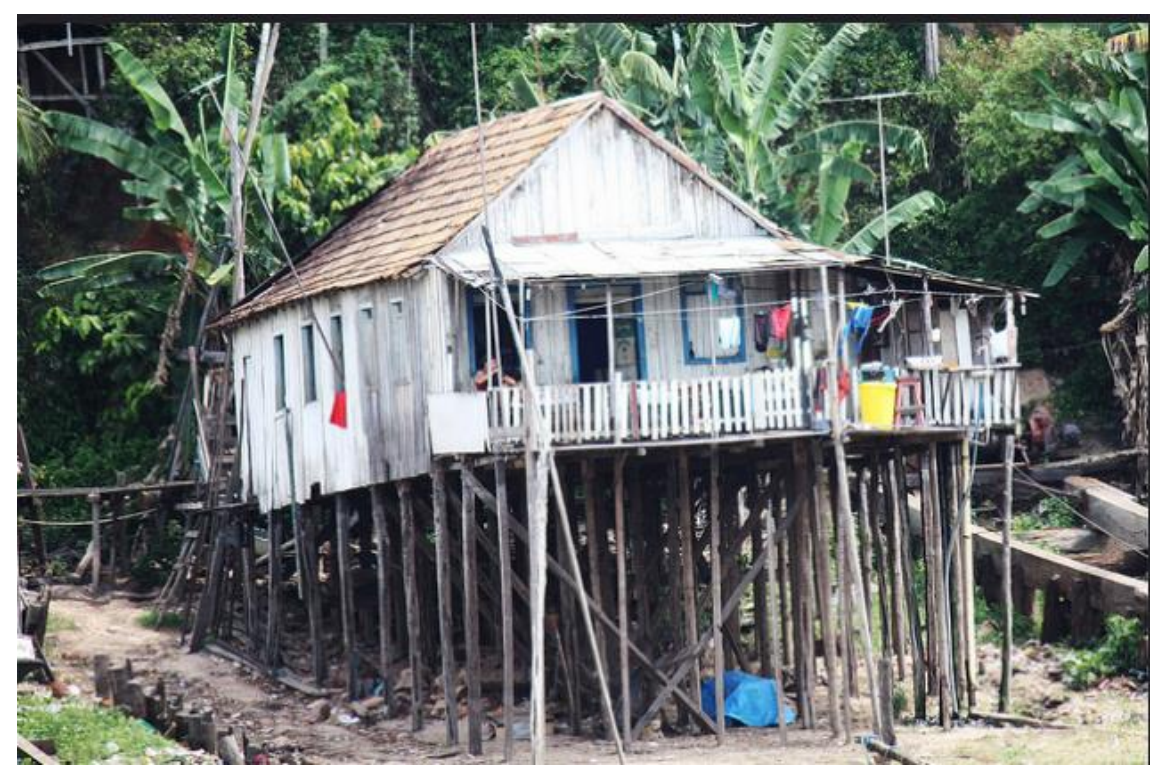

Figura 149. Palafita, margem do Rio Negro-AM, Brasil.

Fonte: https://bit.ly/2BtxFhw, acessado em 17/04/2018. 


\subsection{Casas flutuantes}

Das casas flutuantes ao longo do rio Amazonas (Figuras 150 a 158).

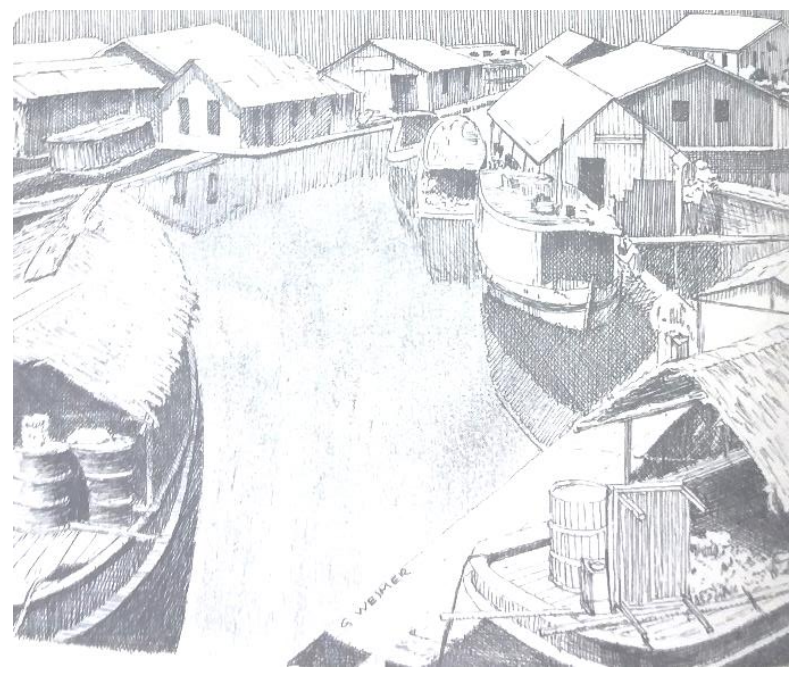

Figura 150. O porto de Manaus: um emaranhado de balsas e barcos. Fonte: Gunter, 2005

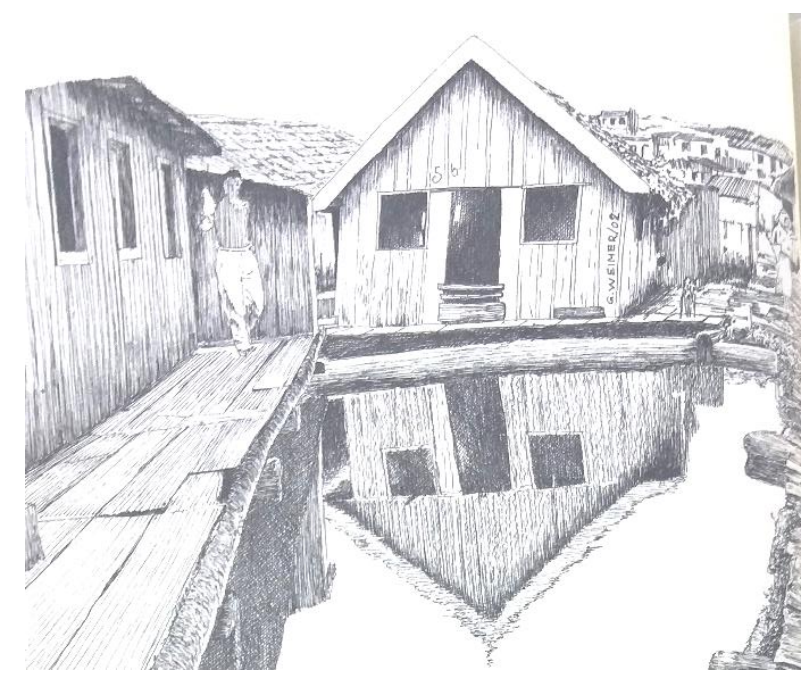

Figura 151. Casas em forma de balsas no porto de Manaus. Fonte: Gunter, 2005.

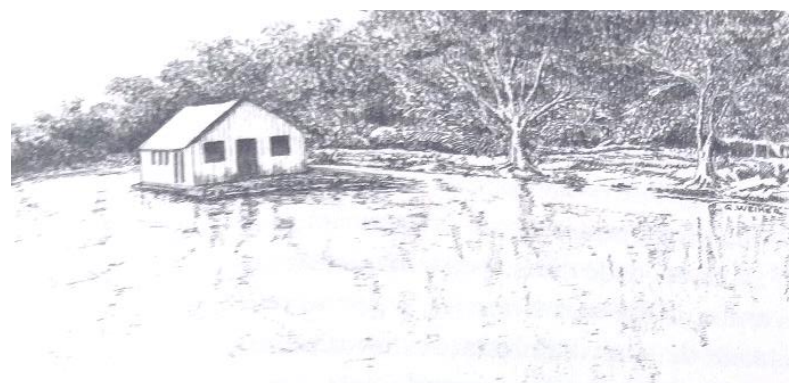

Figura 152. Uma balsa no Rio Solimões com a dupla função de transportadora e de moradia. Fonte: Gunter, 2005. 


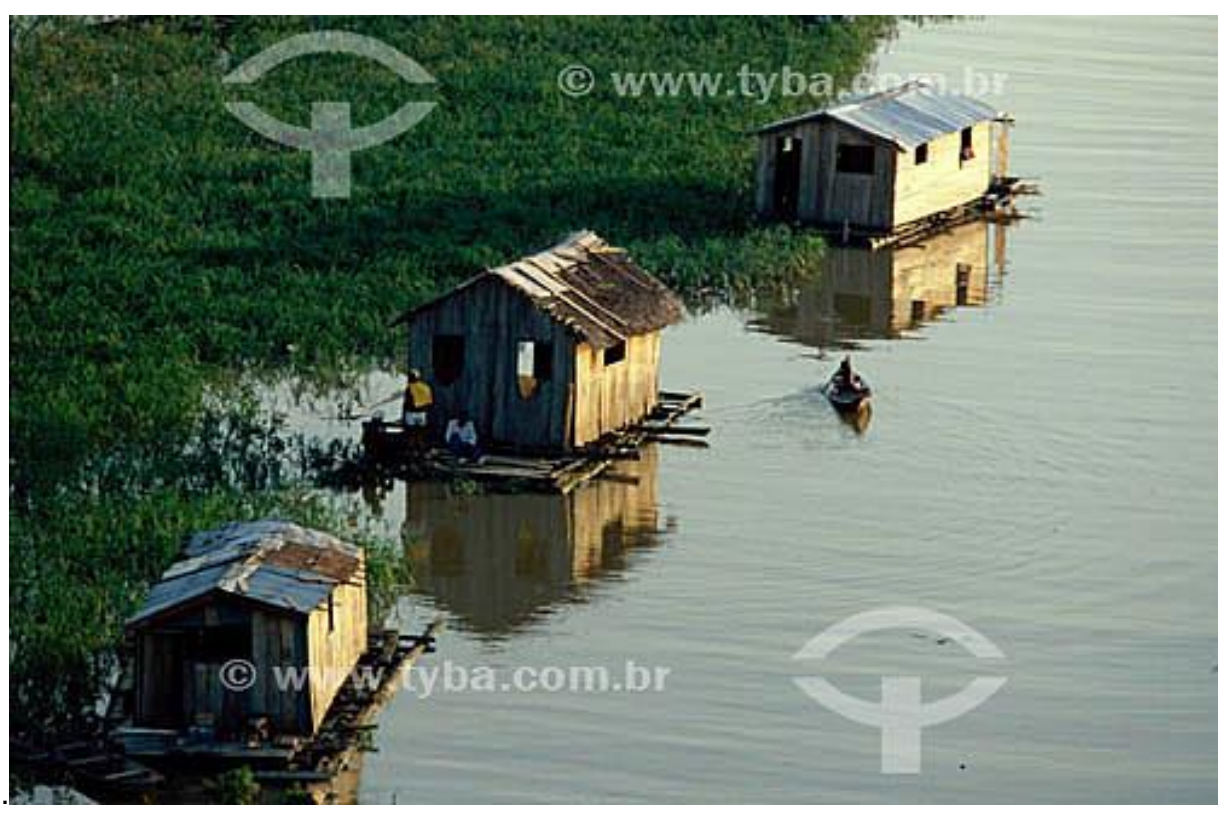

Figura 153. Casas flutuantes e barco da população ribeirinha - Manaus - AM - Brasil. Fonte: https://bit.ly/2LdHfoc, acessado em 17/04/2018.

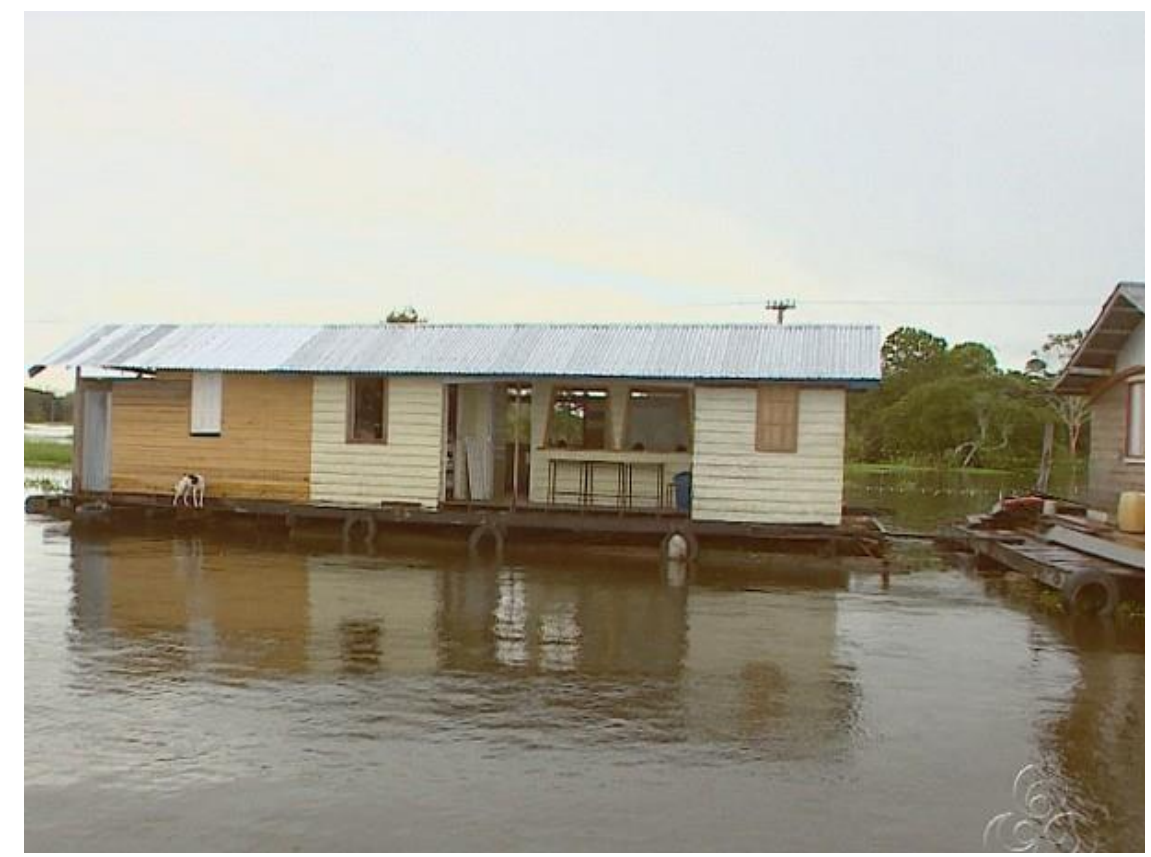

Figura 154. Casa flutuante.

Fonte: https://glo.bo/2OUEJpd, acessado em 17/04/2018. 


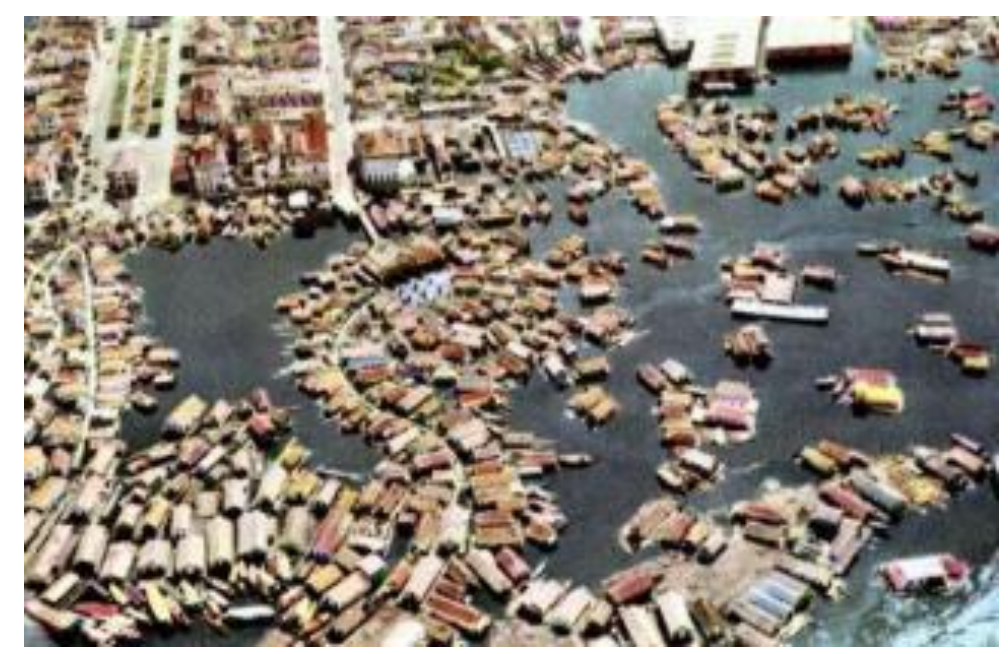

Figura 155. Cidade flutuante em Manaus/AM (1960).. Fonte: https://bit.ly/2N8qIEa, acessado em 17/04/2018.

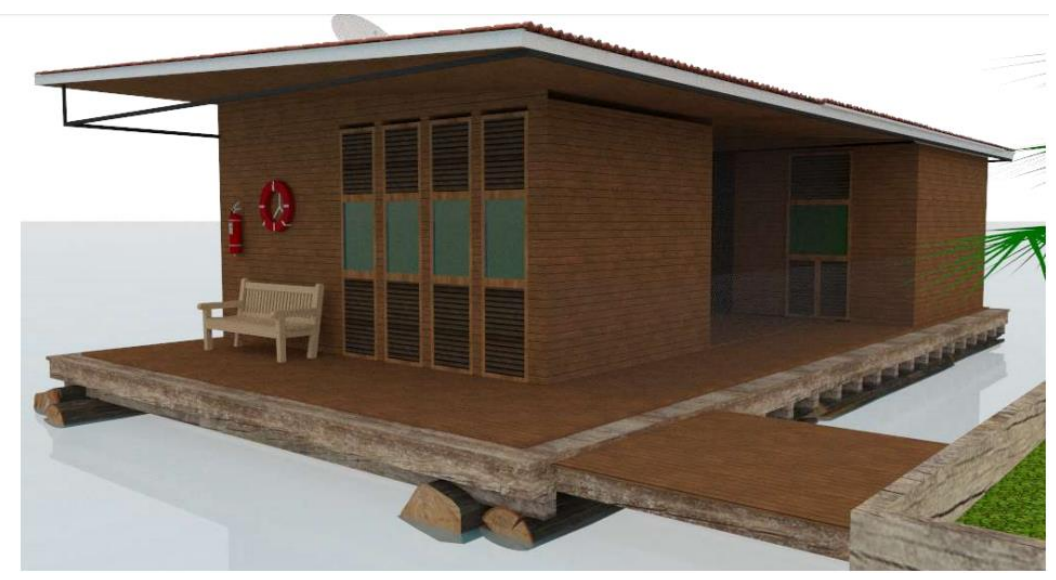

Figura 156. Perspectiva da residência projetada Fonte: https://bit.ly/2N8qIEa, acessado em 17/04/2018.

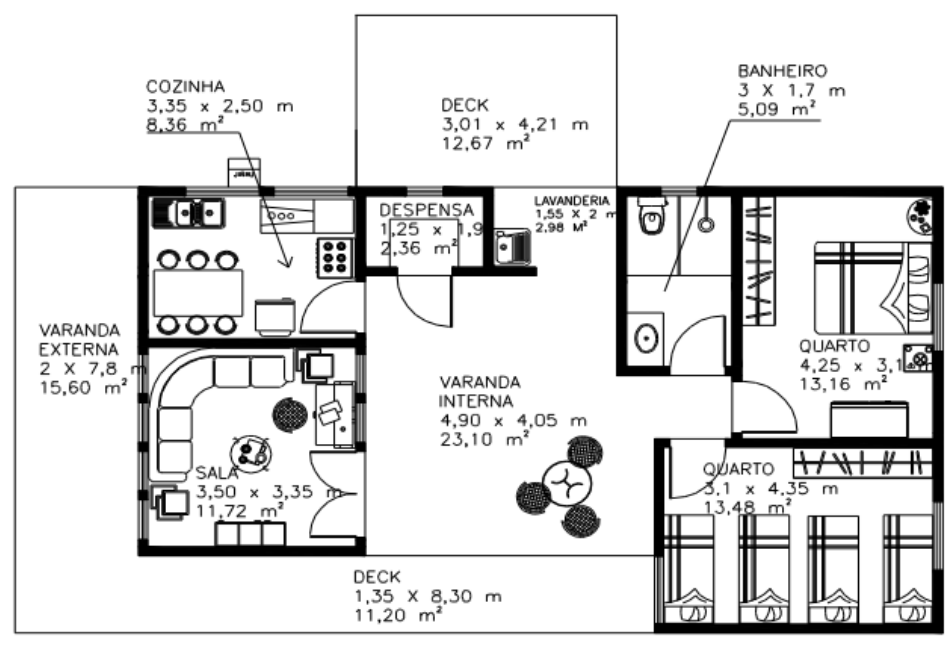

PLANTA BAIXA AREA INTERNA $89.73 \mathrm{~m}^{2}$

COM LAY-OUT AREA DA PLATAFORMA $129.29 \mathrm{~m}^{2}$

Figura 157. Plantaa baixa.

Fonte: https://bit.ly/2N8qIEa, acessado em 17/04/2018. 


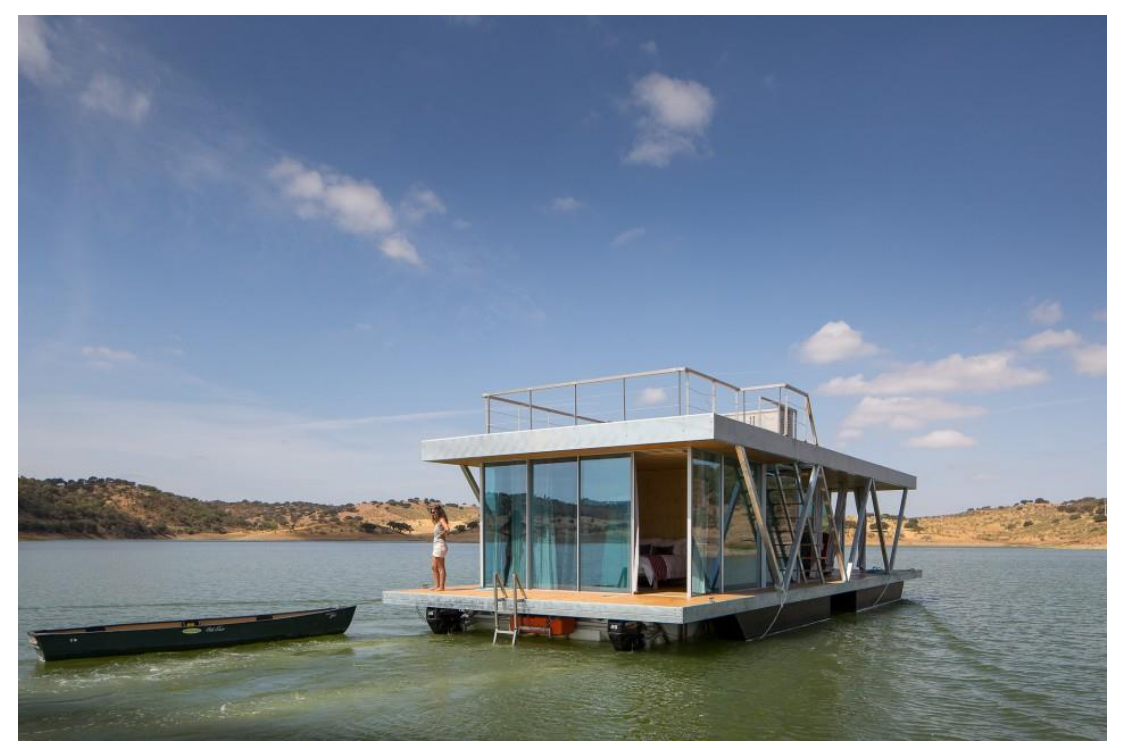

Figura 158. Casas barco.

Fonte: https://bit.ly/2BlwsDp, acessado em 17/04/2018.

\subsection{Casas dos campos}

Das casas dos campos, há grande quantidade de campos no país e diversos tipos de casas (Figuras 162 a 164).

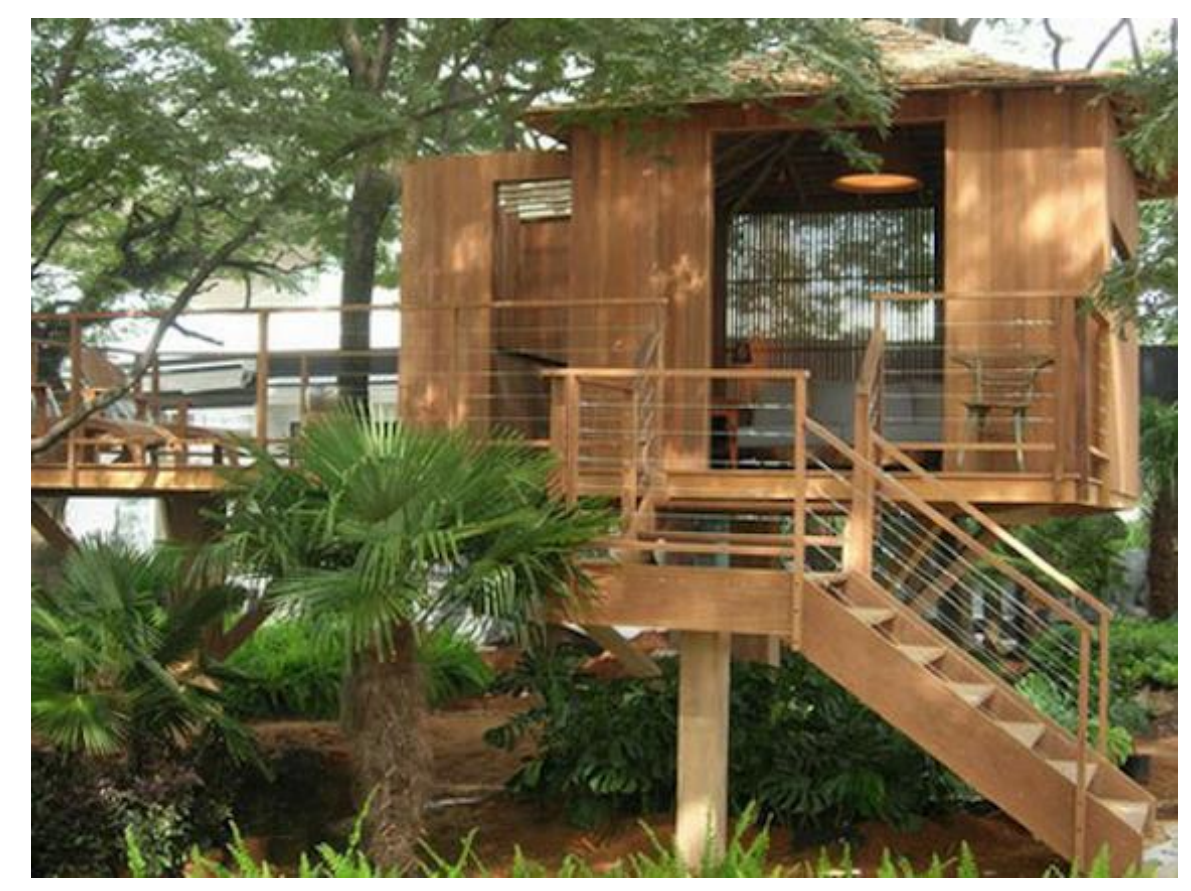

Figura 162. perspectiva casa de campo. Fonte: https://bit.ly/2BIwsDp, acessado em 17/04/2018. 

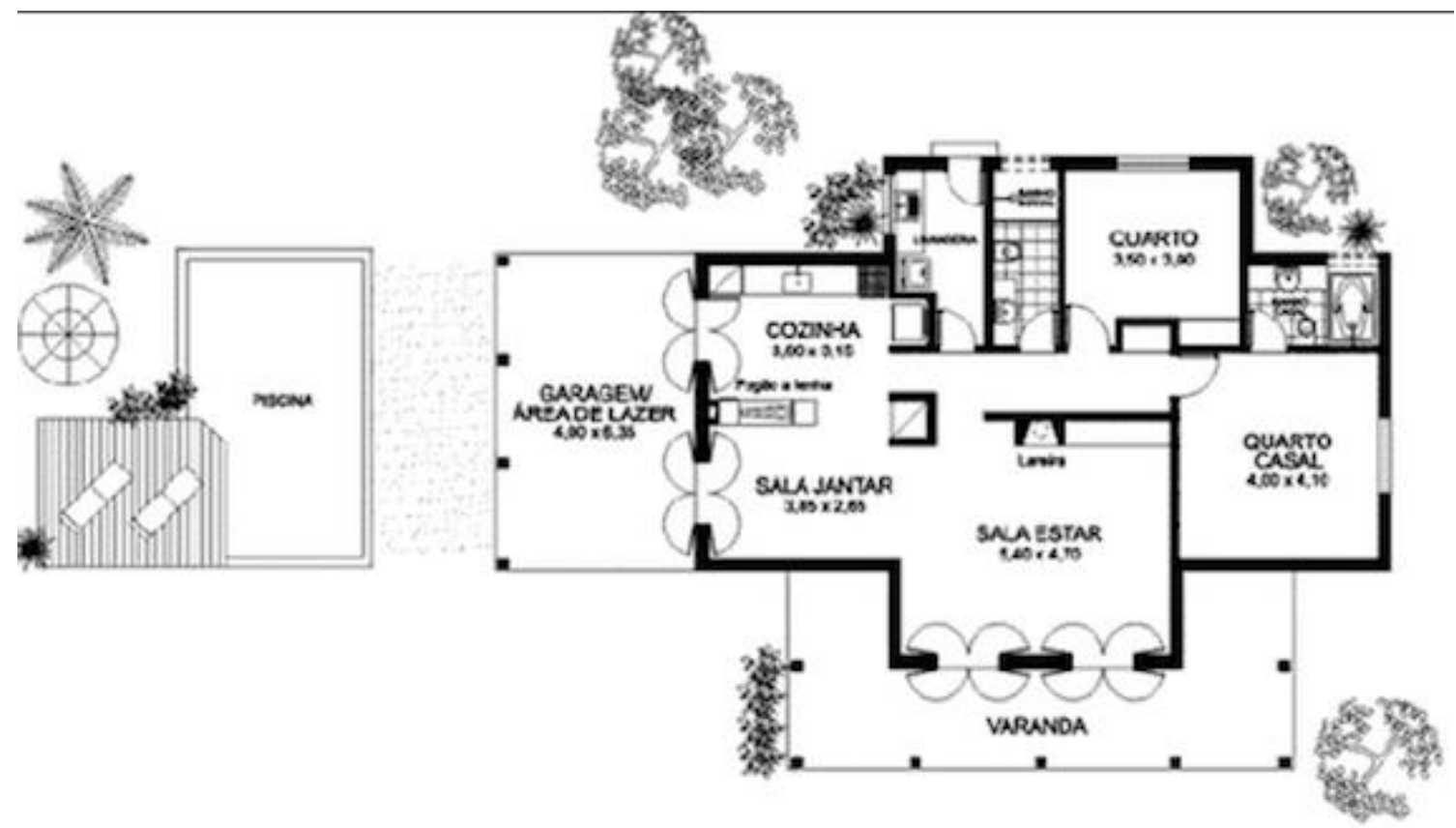

Figura 163. planta de casa de campo.

Fonte: https://bit.ly/2nXBouk, acessado em 17/04/2018.

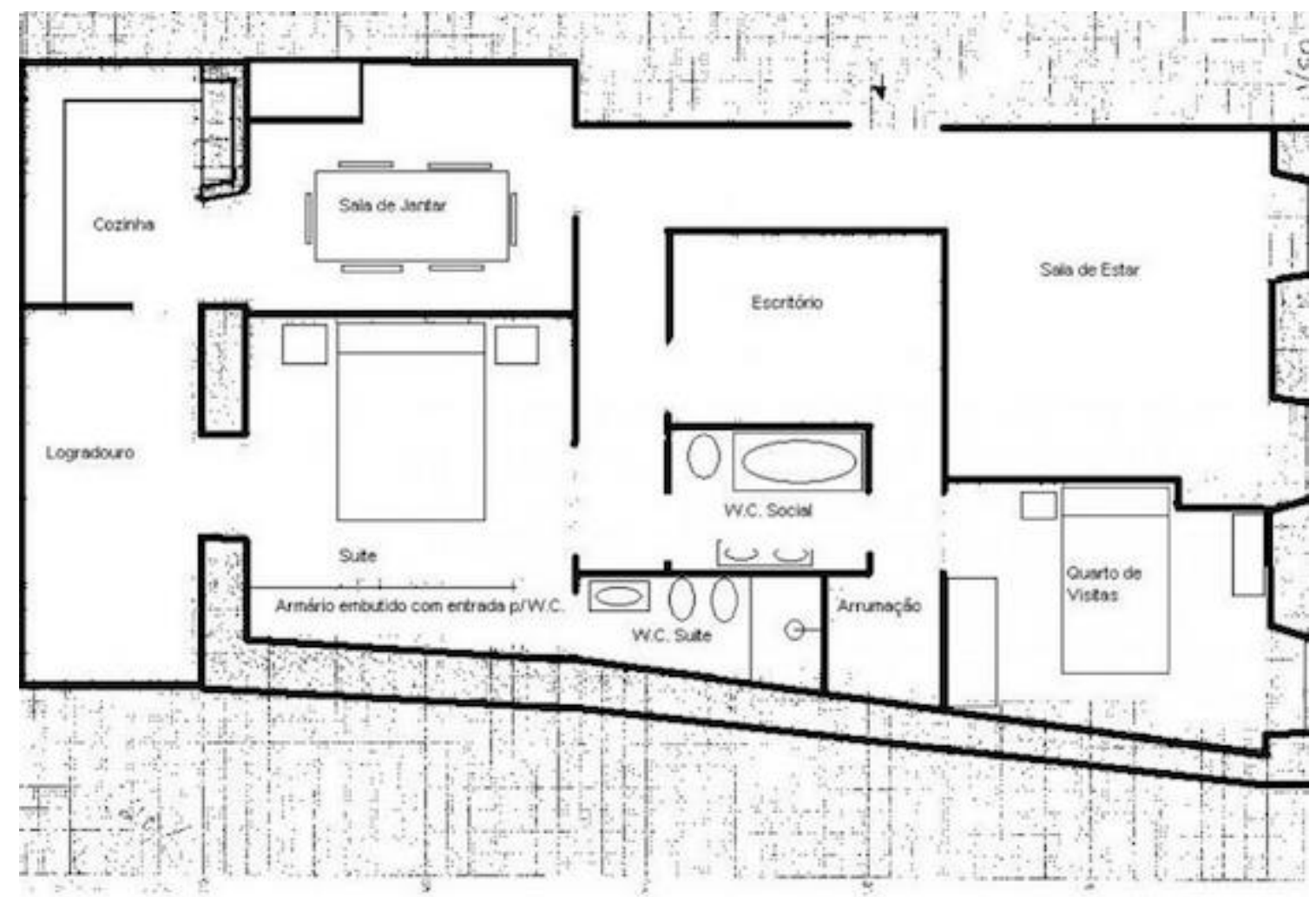

Figura 164. planta de casa de campo.

Fonte: https://bit.ly/2nXBouk, acessado em 17/04/2018. 
Das favelas urbanas, que foram se constituindo no decorrer dos anos por pessoas de baixa renda, sem condições de viver nas cidades que possuem padrão de vida alto e com altos custos (Figuras 165 e 168).

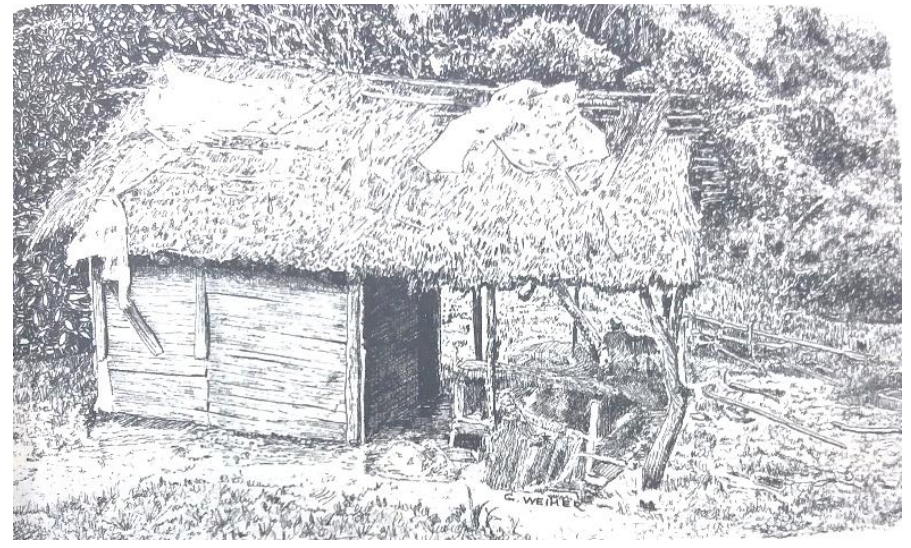

Figura 165. Caban de tábua em Dom feliciano, Rio Grande do Sul. Fonte: Gunter, 2005.

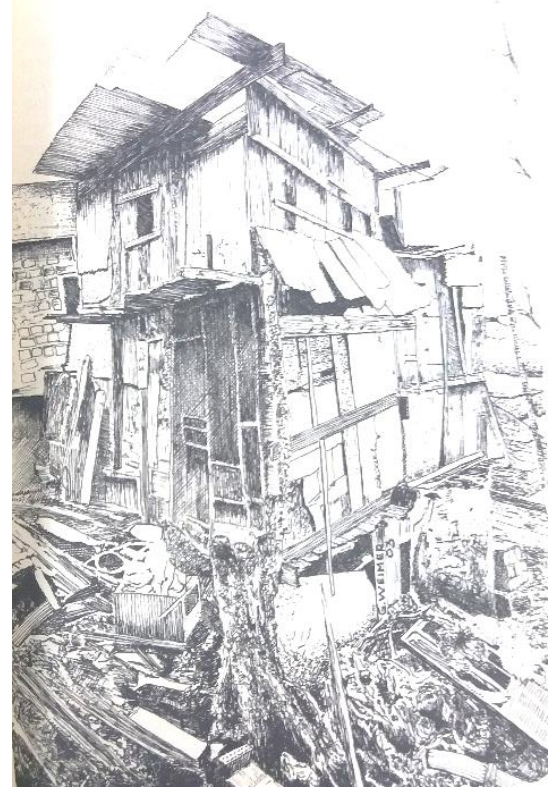

Figura 166. Casa na favela da rocinha, Rio de Janeiro. Fonte: Gunter, 2005.

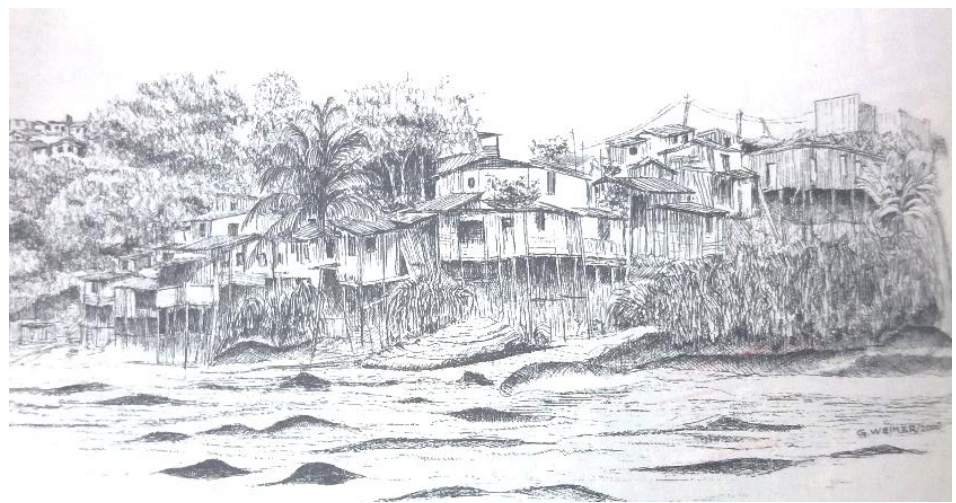




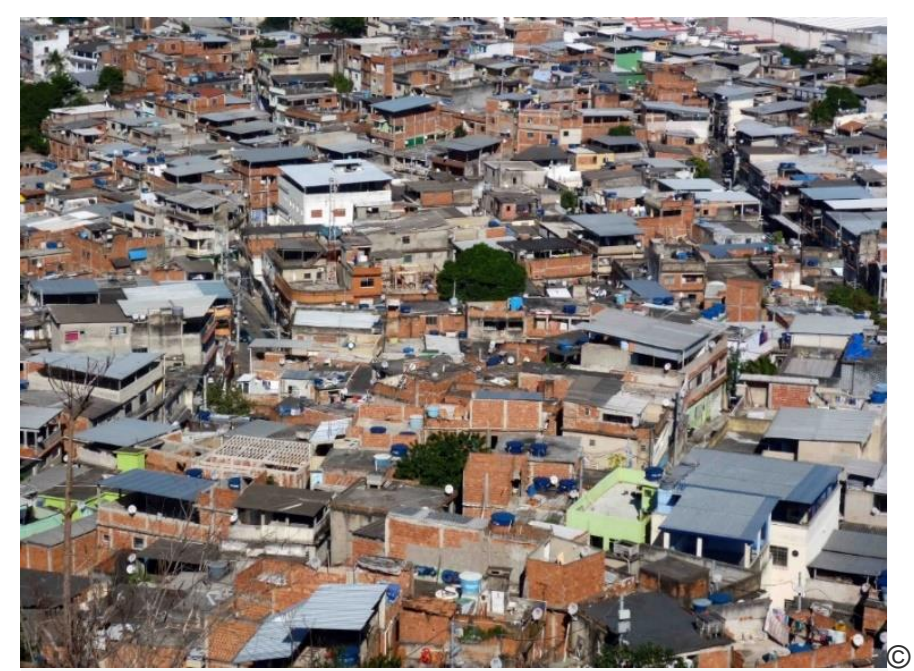

Figura 168. Favelas.

Fonte: https://bit.ly/2nXBouk, acessado em 17/10/2017

\subsection{Docência Universitária}

O processo educativo ainda nas sociedades primitivas era informal, chamava-se "enculturação". O conhecimento para as futura gerações transmitia-se pela convivência. Assim, novos indivíduos integravam-se a ordem social, onde os valores culturais limitavamse à memória, única fonte de registro, Everton Brito Costa (Revista UNIGRAN, 2009).

A partir de 13.000 anos A.C. surgem os primeiros ensaios da escrita: desenhos em pedras nas cavernas pré-históricas. A Mesopotâmia foi considerada a primeira civilização a produzir escrita, o que tornou o processo educativo formal, uma ferramenta capaz de demarcar os eventos ocorridos ao longo do tempo. Transformou os fatos menos suscetíveis a deturpação e/ou esquecimento. Everton Brito Costa (2009).

De acordo com Aurélio Buarque de Holanda, "docência é a relação dos ensinamentos, magistério e professorado com a universidade e seus alunos". A carreira docente é o relacionamento do conhecimento com produção, sistematização, transmissão e sua finalidade social. Até bem pouco tempo atrás bastava diploma de graduação para se tornar professor universitário. Era o "auxiliar de ensino", jovem que se preparava ao magistério, para substituir o "licenciado de longa data", Antônio Joaquim Severiano (USP, 2008).

Hoje a nova realidade mudou este contexto, docência universitária é adquirida pelo curso de pós-graduação. O papel do professor na universidade também cambiou. Culturalmente, as academias de arquitetura e engenharia não sofreram grandes alterações, os modelos acadêmicos se mantêm tradicionais. Já o mesmo não se pode dizer sobre as pessoas, tanto alunos, quanto mestres. O Professor não é mais a única, nem a principal, fonte do saber. Ele é um ser humano que, quando não exerce a docência, também atua no seu cotidiano sobre a influência da tecnologia. Antônio Joaquim Severiano (2008).

Os novos estudantes do ensino superior são personagens detentores de conhecimentos pré-adquiridos. Eles aprendem por interações totais, racionais e afetivas num mundo policromático e polifônico. Os jovens aprendem no caos, entretanto, não são, necessariamente, um caos. São analíticos em seus aspectos emocionais, intuitivos e 
criativos. A linearidade, definitivamente, não é a tônica do moderno jovem universitário. Joaquim Severiano (2008).

\subsection{Vídeo Aulas (Audiovisual)}

"A humanidade aprendeu, desde tempos imemoriáveis, que contar histórias era uma boa maneira de transmitir conhecimento"; "assistir filmes é uma prática social tão importante, do ponto de vista da formação, quanto à leitura de livros", Duarte (2002).

Audiovisual é a comunicação conjunta de elementos visuais com sons utilizados em movimentos que vinculam espaço e tempo. Para obter, sucesso o filme deve contagiar e emocionar o espectador com sua linguagem afetiva. Acontece a apresentação de uma "realidade" pelo olhar de outra pessoa.

A educação acadêmica faz parte da própria história do audiovisual. Os diretores e produtores consideram o cinema como "poderoso instrumento de instrução, ilustração, motivação e exemplo". O que há de novo é a experiência cultural que as tecnologias de interação, informação e comunicação nos acrescentam. Não reconhecemos a linguagem audiovisual separada da história que é retratada num filme, cada película fala por imagens, sons e construções dramáticas da vida.

\section{METODOLOGIA}

Para transformar ensino arquitetônico, emoção e sentimento num feito educacional concreto, em ritmo consistente e personalizado para a aprendizagem do desenho da casa popular, isto, com a utilização audiovisual, vários procedimentos foram necessários. Apresenta-se agora a metodologia para este estudo de tese de maneira a criar vídeo aulas para atingir estudantes universitários.

\subsection{Pesquisa Bibliográfica}

Foram investigadas a fundo os conceitos de Casa humilde e seus Desenhos, bem como, os aspectos que envolvem o Direito à Habitação Popular. Intenta-se dominar o mecanismo que regeu (e ainda rege) este programa de edificação arquitetônico peculiar e tão necessário para o Brasil e América Latina.

\subsection{Experiência Acadêmica \& Pesquisa Focal}

Para o auxílio no planejamento de Vídeo Aulas com possibilidades expressivas para o ensino do desenho da casa humilde, foi lançado mão de pesquisas quantitativas e qualitativas, realizadas por Ricardo Machado desde 2012 no Centro Universitário de Brasília, Brasil. Até o presente momento, 2017, cinco anos de averiguação.

Tal investigação realizada abrangeu informações de alunos ingressantes do curso de Arquitetura \& Urbanismo e, também, Engenharia Civil, com idades entre 18 e 24 anos. Grupo de amostragem composto por 36,52 \% de homens e 63,48 \% mulheres. Então, pretende-se utilizar aqueles dados colhidos para elaboração do presente trabalho. Por outro lado, aspira-se ainda realizar novas pesquisas com o grupo focal. 
Também, para realização deste estudo, foram empregadas as informações coletadas durante o ministério, nas disciplinas de Desenho Técnico e Computação Gráfica. Aulas de graduação com conteúdos igualmente ministrados às turmas desde o ano de 2012, onde foi aplicada intensa didática com a ferramenta "vídeo aulas", porém, de maneira "convencional". Por outro lado, também não ficarão de fora do trabalho informações e experiências docentes do UniCEUB. Bem como, sua experiência liberal no fazer arquitetônico e realização audiovisual.

\subsection{Roteiro Audiovisual}

As pesquisas revelam "o que é necessário para que o audiovisual educativo alcance os estudantes". Informações como: Quais características específicas Vídeo Aula deverá conter; Qual dramatização poderia interessar aos alunos; Qual organização dos conteúdos acadêmicos seria mais receptiva e efetiva e; Qual(s) gênero(s) de linguagem audiovisual seria adotado no planejamento do texto.

Houve a eleição das informações pertinentes para balizar a composição de um "roteiro audiovisual consistente". Evidencia-se preservar o eterno antagonismo acadêmico: "aprender versus aprovar". Conflito magno, onde a missão do mestre em ensinar se confronta com a necessidade do aluno de passar, muitas vezes "a qualquer custo".

"Um bom roteiro não é a única condição para o planejamento audiovisual eficiente do enredo, tempo e custos, mas é fundamental para a preparação adequada de um filme" (RODRIGUES, 2005).

Portanto, o preâmbulo da pesquisa com o grupo focal definiu qual "formato audiovisual" deverá ser adotado naquele roteiro, ou seja, decide as seguintes possibilidades: Seriado (educativo) com divisão em capítulos e temporadas de acordo com módulos de ensino do desenho da casa popular, ou; Filme de Longa Metragem composto por uma trilogia acerca do tema, ou; Documentário Dramático sobre o assunto, ou; Sucessão cadenciada de diversas Películas de Curta Metragem; ou, quem sabe? Mistura de vários formatos discriminados.

Metodologicamente, o roteiro deriva da pesquisa. Então, este texto audiovisual tem a estrutura de maneira a combater os "esquecimentos de conteúdos". Fenômeno acadêmico tão presente nas universidades contemporâneas. Tal "patologia universitária ou mal do século" acadêmico, nesta idealização de projeto, receberá o nome de "Amnésia Estudantil".

\section{RESULTADOS E DISCUSSÃO}

Os resultados mostram o planejamento, teorias, pesquisas e capacitações necessárias para desenvolver um roteiro audio visual, que guie vídeo aulas. $E$, assim, ter esse instrumento como auxílio na formação de estudantes de arquitetura e urbanismo.

No mundo tecnológico, temos acesso a aparelhos de comunicação e entretenimento que revolucionaram a maneira de se pensar e ver o mundo. Em meio a tantas mudanças é necessário pensar em ferramentas tecnológicas que contribuam com o aprendizado dos estudantes de forma prazerosa, divertida e eficaz. 


\section{CONSIDERAÇÕES FINAIS}

Com este trabalho foi possível mesclar materiais teóricos de diferentes campos de conhecimento em prol do objetivo de fazer um roteiro para ensinar vídeo aulas a respeito de habitações populares.

Foi possível: entender o que é o desenho e como vem sendo desenvolvido dentro da arquitetura nessa era tecnológica; Investigar as casas humildes brasileiras em diferentes épocas e regiões; Buscar exemplos dessas casas humildes; Analisar a comunicação audiovisual; Criar uma metodologia de transmissão de conteúdos de arquitetura por meio de imagens, sons e dramaticidade. 


\section{REFERÊNCIAS}

ÁBALOS, IÑAKI. A Boa-Vida: Visita Guiada ás Casas da Modernidade. Editora Gustavo Gilli, 2003

COSTA, EVERTON BRITO OLIVEIRA. Revista Centro Universitário de Grande Dourados, v 1, Junho, 2009.

DUARTE, ROSÁLIA. Cinema e Educação. Belo Horizonte. Editora Autêntica, 2002.

EASTMAN, CHUCK; TEICHOLZ, PAUL; SACKS, RAFAEL \& LISTON, KATHLEEN. Manual de BIM: Um Guia de Modelagem da Informação da Construção para Arquitetos, Engenheiros, Gerentes, Construtores e Incorporadores. Editora Bookman, 2014.

FERREIRA, AURÉLIO BUARQUE DE HOLANDA. Dicionário Aurélio da Língua Portuguesa Edição histórica 100 anos. Editora Positivo Livros, 2010.

FERRÉS, J. Vídeo e Educação. Porto Alegre. Editora Artes Médicas Sul, 1996.

MIRANDA, C. E. A. A Educação do Olho. Cadernos CEDES, número 54, Campinas, São Paulo, 2005.

RANDOLPH, P.; SPRINGER, CLIFFORD H. E DOBROVOLNY, JERRY S. HOELSCHER. Gráficos para Engenheiros Comunicação Visual e Design. Editora John Wiley \& Sons, 1968.

RODRIGUES, CHRIS: O Cinema e a Produção, Editora FAPERJ e DP\&A Editora, 2005. SARTRE, JEAN PAUL. O imaginário. Editora Ática, 1996.

SEVERIANO, ANTONIO JOAQUIM. Cadernos de Pedagogia da Universidade de São Paulo. Editora USP.

WEIMER, GUNTER. Arquitetura Popular Brasileira. Editora: Wmf, 2005. 